\title{
Fibroblast Growth Factor Receptors (FGFRs) and Noncanonical Partners in Cancer Signaling
}

\author{
Harriet R. Ferguson ${ }^{1}$, Michael P. Smith ${ }^{1, *(\mathbb{D})}$ and Chiara Francavilla $1,2, *$ (D) \\ 1 Division of Molecular and Cellular Function, School of Biological Science, Faculty of Biology Medicine and \\ Health (FBMH), The University of Manchester, Manchester M13 9PT, UK; \\ harriet.ferguson-2@postgrad.manchester.ac.uk \\ 2 Manchester Breast Centre, Manchester Cancer Research Centre, The University of Manchester, \\ Manchester M20 4GJ, UK \\ * Correspondence: michael.smith-8@manchester.ac.uk (M.P.S.); chiara.francavilla@manchester.ac.uk (C.F.)
}

check for updates

Citation: Ferguson, H.R.; Smith, M.P.; Francavilla, C. Fibroblast Growth Factor Receptors (FGFRs) and Noncanonical Partners in Cancer Signaling. Cells 2021, 10, 1201.

https://doi.org/10.3390/cells10051201

Academic Editors: Antoni Wiedlocha and Malgorzata Zakrzewska

Received: 15 April 2021

Accepted: 9 May 2021

Published: 14 May 2021

Publisher's Note: MDPI stays neutral with regard to jurisdictional claims in published maps and institutional affiliations.

Copyright: (c) 2021 by the authors. Licensee MDPI, Basel, Switzerland. This article is an open access article distributed under the terms and conditions of the Creative Commons Attribution (CC BY) license (https:/ / creativecommons.org/licenses/by/ $4.0 /)$.

\begin{abstract}
Increasing evidence indicates that success of targeted therapies in the treatment of cancer is context-dependent and is influenced by a complex crosstalk between signaling pathways and between cell types in the tumor. The Fibroblast Growth Factor (FGF)/FGF receptor (FGFR) signaling axis highlights the importance of such context-dependent signaling in cancer. Aberrant FGFR signaling has been characterized in almost all cancer types, most commonly non-small cell lung cancer (NSCLC), breast cancer, glioblastoma, prostate cancer and gastrointestinal cancer. This occurs primarily through amplification and over-expression of FGFR1 and FGFR2 resulting in ligand-independent activation. Mutations and translocations of FGFR1-4 are also identified in cancer. Canonical FGF-FGFR signaling is tightly regulated by ligand-receptor combinations as well as direct interactions with the FGFR coreceptors heparan sulfate proteoglycans (HSPGs) and Klotho. Noncanonical FGFR signaling partners have been implicated in differential regulation of FGFR signaling. FGFR directly interacts with cell adhesion molecules (CAMs) and extracellular matrix (ECM) proteins, contributing to invasive and migratory properties of cancer cells, whereas interactions with other receptor tyrosine kinases (RTKs) regulate angiogenic, resistance to therapy, and metastatic potential of cancer cells. The diversity in FGFR signaling partners supports a role for FGFR signaling in cancer, independent of genetic aberration.
\end{abstract}

Keywords: FGFRs; FGFs; signaling; cancer; tumorigenesis; coreceptors; cell adhesion molecules; extracellular matrix; receptor tyrosine kinase; EGFR

\section{Introduction}

The superfamily of Receptor Tyrosine Kinases (RTKs) comprises 20 subfamilies of cell-surface receptors with conserved structures. Upon activation, RTKs undergo dimerization, internalization and initiate large-scale tyrosine phosphorylation responses and signaling cascades to regulate cell growth, proliferation, survival and differentiation [1]. The importance of RTKs in cancer was established with the successful introduction of Gleevec, Herceptin and Iressa, the first RTK inhibitors to show antitumor effects approved for clinical use in the early 2000s [2]. In tandem, the role of RTKs in relation to development, tissue homeostasis and other diseases was a growing body of research.

Among RTKs, the family of Fibroblast Growth Factor Receptors (FGFRs) comprises four genes that give rise to at least seven different receptor isoforms. These receptors are differentially activated by one of the 22 Fibroblast Growth Factor (FGF) ligands with known FGFR-binding activity, which are nearly ubiquitously expressed in all adult tissues and play a critical role in development, tissue homeostasis and human diseases [3]. Like other RTKs, FGFR1-4 have been implicated in cancers arising from nearly all tissue types [4]. In-line with the number of ligands and receptor variants, FGFR signaling is highly contextspecific, which is evidenced by its tumorigenic or tumor suppressor roles in different 
cancer types. For example, FGFR2 loss of function mutations have been reported in $10 \%$ of melanoma tumors and cell lines [5] as well as in bladder cancers. FGFR2 downregulation has also been reported in bladder cancer [6] and in subtypes of hepatocellular carcinoma (HCC) [7], whereas in other cancer types/subtypes with overexpression of the FGFR2, including gastric cancer [8,9], triple negative breast cancer [10] and osteosarcoma [11], inhibition of the receptor decreases cancer cell proliferation and cell survival in vitro. Beyond canonical FGFR signaling and signaling partners, the FGFR interactome is large, and how noncanonical interaction partners regulate FGFR signaling in tumorigenesis is not fully understood $[12,13]$. Cell surface FGFR interactions with extracellular matrix (ECM) proteins, cell adhesion molecules (CAMs), coreceptors and other RTKs are known to be critical during development [14]. Such heterotypic interactors of FGFR also have a role in tumorigenesis and tumor progression. Here, we outline the current understanding of the role of heterotypic FGFR interactors in regulating FGFR signaling in cancer using selected examples to illustrate each concept. First, we will focus on the role of canonical FGFR signaling partners, such as heparan sulfate proteoglycans (HSPGs) and Klotho, in FGFR signaling. Finally, we discuss noncanonical signaling partners of FGFR for which a role in cancer has been identified.

\section{The FGFR Family}

FGFR was first described as a receptor for basic fibroblast growth factor (bFGF, later termed FGF2) purified from chicken embryos with an extracellular domain containing three immunoglobulin-like looped domains (Ig domains) and an acidic region (known as the acid box), a single transmembrane domain, a long juxtamembrane domain and an intracellular domain with two tyrosine kinase domains (Figure 1A) [15]. Previously identified FLG in human cDNA screens [16], now known as FGFR1, was shown to respond to acidic FGF (aFGF, then renamed FGF1) [17]. FGFR2, originally BEK, was identified as sharing tyrosinekinase similarity to FGFR1 [18], leading to the discovery of RTKs encoded by the genes FGFR3 and FGFR4 with highly conserved structures to FGFR1 and FGFR2 [19,20]. FGFR5, also known as FGFR like 1 (FGFRL1), is considered a fifth member of the FGFR family. Two isoforms isolated from cDNA libraries, FGFR5 $\beta$ and FGFR5 $\gamma$, have three and two Ig domains, respectively, differentiating them from the other FGFR family members. Both FGFR5 isoforms lack a tyrosine kinase domain, and as such were traditionally considered negative regulators of FGFR1-4 [21,22]. Characterization of FGFR5-regulated signaling has revealed that FGFR5 can act as a coreceptor to enhance FGFR1 signaling [23,24].

In the third Ig domain (IgIII) of the extracellular domain of FGFR1-3, alternative splicing of three exons gives rise to two different isoforms, FGFR(1-3)-IgIIIb and -IgIIIc (Figure 1B) [25]. The alternatively spliced FGFR isoforms have different ligand-binding affinities (Figure 1C) [26,27]. For instance, the binding of FGFR2-IgIIIb-specific keratinocyte growth factor (KGF, known as FGF7) to FGFR2-IgIIIc can be induced by introducing an FGFR2b-specific IgIII variable region [28]. The IgIII isoforms of FGFR show tissue and developmental stage-specific expression patterns [29]. The IgIIIb variant is preferentially expressed in epithelial tissues, which is regulated by activity of epithelial splicing regulatory protein 1 (ESRP1) and ESRP2 (Figure 1B). Overexpression of ESRP1 and ESRP2 in mesenchymal cells is sufficient to switch expression from the FGFR2-IgIIIc to the FGFR2IgIIIb isoform [30]. Alternative splicing of the extracellular domain of FGFR1 also gives rise to an FGFR $1 \alpha$ type 1 (FGFR1 $\alpha 2)$, FGFR $1 \alpha 2$, FGFR $1 \beta$ and FGFR1 $\gamma$ isoform of the receptor. FGFR $1 \alpha 1 / 2$ have three Ig domains, whereas FGFR1 $\beta$ and FGFR1 $\gamma$ lack the N-terminal IgI domain [31-33]. FGFR1 $\gamma$ differs from FGFR1 $\beta$ in that alternative splicing also skips the exon containing the acid box. This IgI/acid box skipping regulates ligand-binding affinities of the FGFR1 isoforms [33,34]. FGFR1 $\alpha 1$ has a classical FGFR1 structure. FGFR1 $\alpha 2$, however, has a truncated C-terminal kinase domain, subsequently lacking critical tyrosine autophosphorylation sites. As a result, FGFR1 $\alpha 2$ is defective in initiating canonical FGFR1 signaling cascades. An FGFR2 $\beta$ isoform, and an FGFR3 isoform lacking the acid box designated FGFR3 $\triangle \mathrm{AB}$, have also been identified [35-37]. 


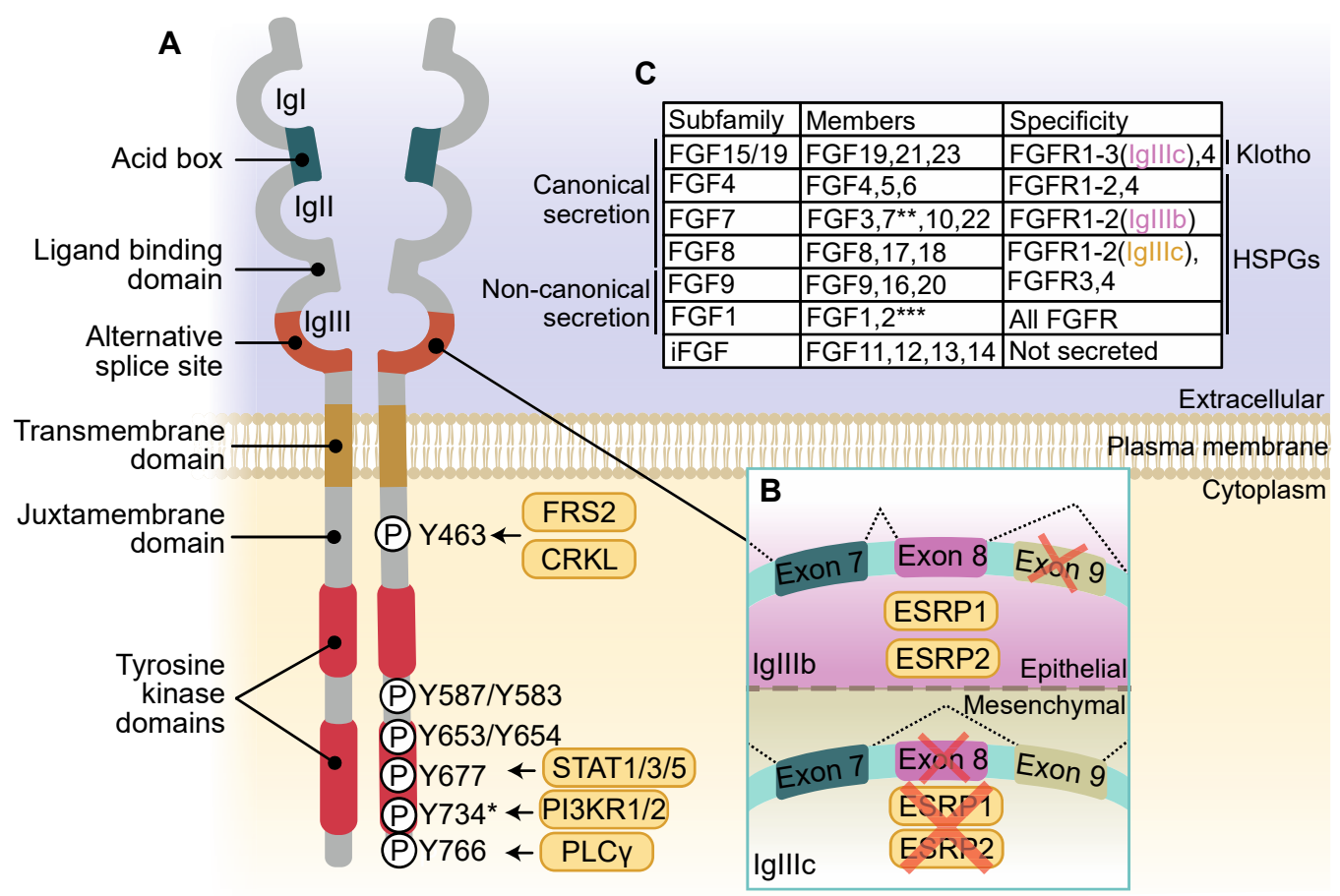

Figure 1. Fibroblast Growth Factor Receptor (FGFR) structure, activation and Fibroblast Growth Factor (FGF)-FGFR specificity. (A) The extracellular domain of FGFR comprises three immunoglobulinlike looped domains (IgI-IgIII) with an acid box that sits between IgI and IgII. FGF binds the receptor between IgII and IgIII. A long juxtamembrane domain contains the binding site for FGFR substrate 2 (FRS2) and chicken tumor virus no. 10 regulator of kinase (CRK) or the closely related CRK-like (CRKL). Across two tyrosine kinase domains, phosphorylated tyrosine residues are required for full activation of the receptor and docking of signal transducer and activator of transcription $1 / 3 / 5$ (STAT1/3/5), p85 subunit of phosphatidylinositide 3-kinase subunit $\alpha / \beta$ (PI3KR1/2) and phospholipase $\mathrm{C}$ gamma (PLC $\gamma$ ). Within IgIII lies an alternative splice site that gives rise to FGFR IgIIIb and IgIIIc isoforms. (B) Epithelial splicing regulatory proteins 1 (ESRP1) and ESRP2 present in epithelial cells regulates inclusion of exon 8 and exclusion of exon 9 to give rise to FGFR-IgIIIb isoform. The absence of ESRP1/2 in mesenchymal cells results in inclusion of exon 9 and exclusion of exon 8 giving rise to IgIIIc isoform. Alternative splicing gives rise to FGFR isoforms with different ligand binding affinities. (C) FGF subfamilies have different FGFR-binding affinities and mechanisms of secretion, or in the case of intracellular FGFs (iFGF) are not secreted. FGFR requires different coreceptors Klotho or heparan sulfate proteoglycan (HSPG) to activate different repertoire of FGFR isoform. * Y734 corresponds to FGFR2-IgIIIb only; ** can bind FGFR2-IgIIIb isoform only; *** cannot bind FGFR2-IgIIIb isoform.

\section{FGFR Activation and Signaling}

Following binding of FGF, FGFRs predominantly form an asymmetric homodimer with the first kinase domain of one molecule interacting with the second kinase domain of its dimerization partner to facilitate transautophosphorylation [38]. Dimerization of the transmembrane domain is negatively regulated by a conserved motif within the C-terminal juxtamembrane domain, likely preventing ligand-independent dimerization [39]. Key signaling events are summarized in Figure 2. Autophosphorylation of specific residues within the intracellular domain recruits specific signaling adaptors to activate different signaling nodules (Figure 1A). Tyrosine (Y) 653 and Y654 of FGFR1 are required for kinase activation and consequent RAS/mitogen activated protein kinase (MAPK) signaling [40], whereas specific autophosphorylation of Y766 is required for docking of the SRC homology 2 (SH2)-domain of phospholipase C gamma (PLC $\gamma$ ) and subsequent PLC $\gamma$ activation [41]. The p85 phosphatidylinositide 3-kinase subunit $\alpha / \beta$ (PI3KR1/2) is recruited to Y734 of FGFR2-IgIIIb in response to FGF10 treatment [42], as is seen for Y760 phosphorylation of 
FGFR3 in response to FGF2 [43]. Crucial to FGFR-RAS-MAPK signaling is the activation of FGFR substrate 2 (FRS2), a lipid-anchored adaptor protein constitutively bound to the juxtamembrane of FGFR [44,45]. FGFR-mediated phosphorylation of Y346 of FRS2 functions as a docking site for the $\mathrm{N}$-terminal $\mathrm{SH} 2$ domain of protein tyrosine phosphatase nonreceptor type 11 (PTPN11, also known as SHP2) [46]. Growth factor receptor-bound 2 (GRB2) is indirectly recruited by PTPN11, and independently downstream of Y196, Y306, Y349 and Y392 FRS2 phosphorylation (Figure 2) [44]. FRS2 recruitment sustains RAS-MAPK signaling in an FGFR-specific manner, in comparison to pan-RTK RAS-MAPK adaptor SH2-containing (SHC) transforming protein 1 (SHC1) [46]. A second adaptor that directly interacts with FGFR is the chicken tumor virus no. 10 regulator of kinase (CRK) and the closely related CRK-like (CRKL). The CRK/CRKL SH2-domain directly binds phosphorylated Y463-FGFR1 [47,48] and can interact with FRS2-GRB2-PTPN11 [49] in a complex containing SHC, breast cancer anti-estrogen resistance protein 1 (BCAR1) and RAP guanine nucleotide exchange factor 1 (RAPGEF1) (Figure 2) [47] to regulate efficient activation of extracellular signal-regulated protein kinase 1/2 (ERK1/2) of the RAS-MAPK pathway $[48,50]$. ERK1/2 signal duration can be regulated by phosphatidylinositol 3,4,5trisphosphate 5-phosphatase 2 (SHIP2), an adaptor of FGFR signaling. SHIP2 interactions with FGFR to mediate a sustained ERK1/2 signal, which is transient in the absence of SHIP2. This is achieved through SHIP2-regulation of FRS2 and recruitment of SRC, protooncogene, non-receptor tyrosine kinase (SRC)-family kinases (SFK) [51]. ERK1/2 directly phosphorylates low-density lipoprotein receptor-related protein 6 (LRP6) at S1490 and T1572 downstream of FGFR2/3, which increases WNT signaling [52]. Ribosomal S6 kinase 2 (RSK2), a serine/threonine kinase activated by 3-phosphoinositide-dependent protein kinase 1 (PDK1) and ERK1/2 phosphorylation, is directly phosphorylated by FGFR3 at sites Y529 and Y707. Respectively, these sites facilitate binding of inactive ERK1/2 and remove autoinhibition of RSK2 (Figure 2) [53,54]. GRB2-associated binding protein 1 (GAB1) is recruited to phosphorylated FRS2, where it is phosphorylated and also recruits PI3K to activate PI3K-AKT signaling [55]. PI3K-AKT signaling downstream of FGFR activation is involved in FGF-mediated angiogenesis [56,57] and negatively regulates ERK1/2 signaling [43]. FGFR1-4 signaling can activate signal transducer and activator of transcription 1 (STAT1), STAT3 and STAT5 signaling (Figure 2) [58-61]. STAT3 binding and subsequent activation are dependent on phosphorylation of a receptor-isoform conserved Y677 (FGFR1) and FGF-activated SRC and non-receptor tyrosine kinase Janus kinase (JAK) [62]. 


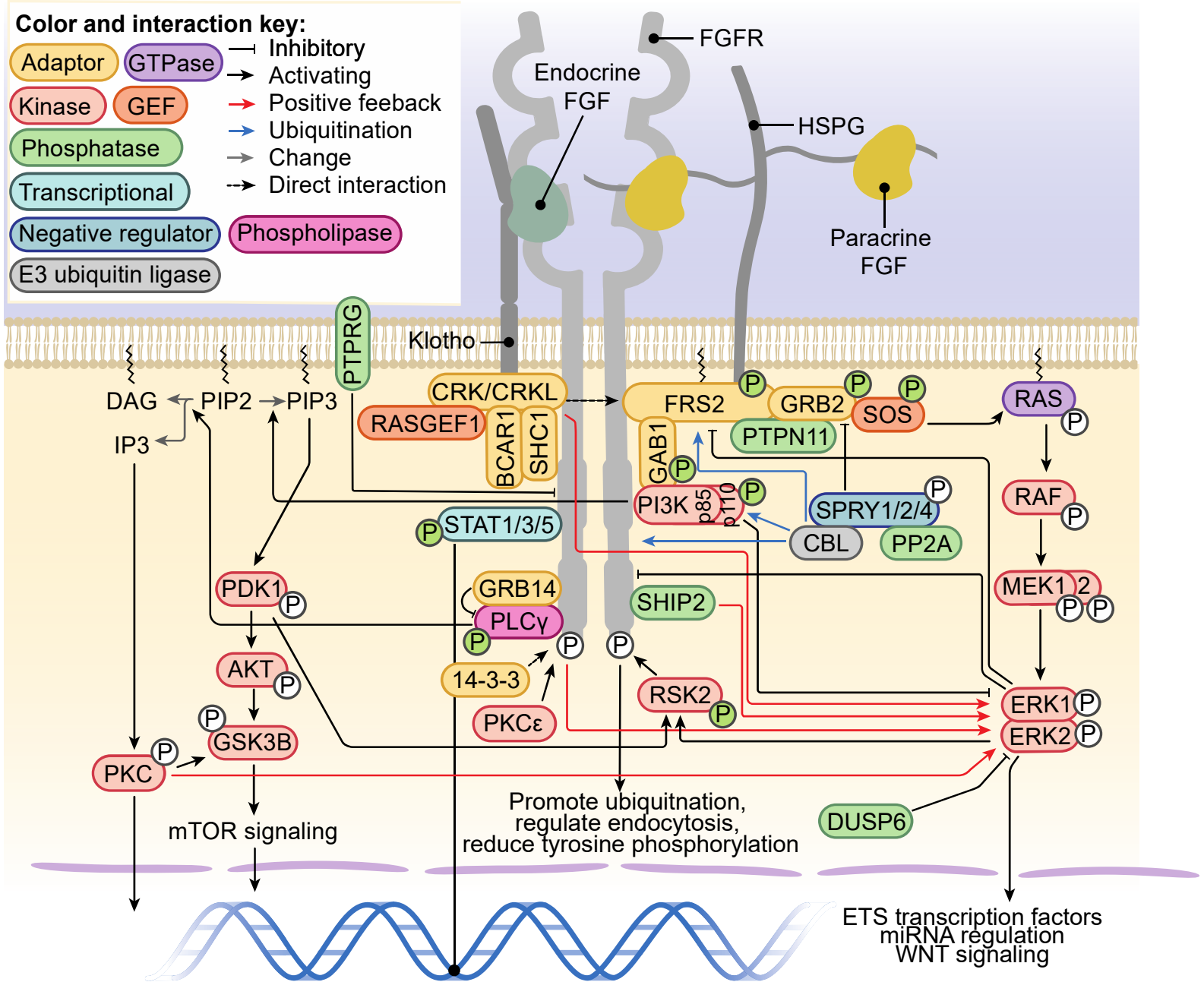

Angiogenesis, proliferation, growth, invasion, migration, survival, metastasis

Figure 2. Fibroblast Growth Factor Receptor (FGFR) signaling partners, pathways and regulation of FGFR signaling Klotho or heparan sulfate proteoglycan (HSPG) are required for activation of FGFR by endocrine or paracrine FGFs, respectively. Binding of the ligand initiates large-scale phosphorylation and activation of intracellular signaling cascades. RAS-mitogen activated protein kinase (MAPK) and phosphatidylinositide 3-kinase (PI3K)-AKT signaling are dependent on FRS2 binding FGFR, which is associated with a CRK/CRKL complex to positively regulate extracellular signal-regulated protein kinase 1/2 (ERK1/2) signaling. ERK1/2 signaling is tightly regulated downstream of FGFR. The PI3K p85 subunit can bind FGFR independently of growth factor receptor bound 2 (GRB2)-associated binding protein 1 (GAB1) to activate AKT signaling through conversion of phosphatidylinositol 4,5-bisphosphate $\left(\mathrm{PIP}_{2}\right)$ to phosphatidylinositol 3,4,5-trisphosphate (PIP 3$)$. PI3K-AKT signaling activates the mammalian target of rapamycin (mTOR) signaling downstream FGFR activation. PLC $\gamma$ binds FGFR and hydrolyses $\mathrm{PIP}_{2}$ to produce diacylglycerol (DAG) and inositol trisphosphate $\left(\mathrm{IP}_{3}\right)$. $\mathrm{IP}_{3}$ activates protein kinase C (PKC) signaling. STAT1/3/5 activation by FGFR results in translocation to the nucleus to regulate transcription. Positive regulators of FGFR signaling include 14-3-3, protein kinase $\mathrm{C} \varepsilon$ (PKC $\varepsilon$ ) and $\mathrm{PIP}_{3}$ 5-phosphatase 2 (SHIP2), whereas negative regulators include SPROUTY 1/2/4 (SPRY1/2/4), E3-ubiquitin ligase CBL (CBL), protein phosphatase 2 A (PP2A), dual specificity phosphatase 6 (DUSP6) and protein tyrosine phosphatase receptor type G (PTPRG). Phosphorylation colored green indicates proteins where activation is dependent on FGFR-mediated tyrosine phosphorylation.

\section{Regulation of FGFR Signaling and FGFR Trafficking}

Mechanisms exist to amplify FGFR-dependent signaling (Figure 2), for example, protein kinase $\mathrm{C} \varepsilon(\mathrm{PKC} \varepsilon)$ phosphorylates $\mathrm{S} 779$ of FGFR1 and FGFR2, a docking site for the adaptor 14-3-3, which binds and amplifies FGFR-RAS-MAPK and FGFR-PI3K-AKT signaling [63,64]. Alternatively, negative feedback mechanisms prevent aberrant FGFR signaling implicated in multiple pathologies including cancer. Active ERK1/2 directly 
phosphorylates a conserved S777 of FGFR1, not dependent on FGFR activation, which when inhibited enhances FGFR signaling [65]. FGFR-dependent activation of ERK1/2 also phosphorylates FRS2 at eight threonine residues to reduce FGFR-FRS2 signaling [66], which in the absence of ERK1/2 can be mediated by p38 MAPK [67]. Activated RSK2, a downstream target of ERK1/2 signaling, binds and phosphorylates S789 of FGFR1 to reduce tyrosine phosphorylation, promote ubiquitination and regulate endocytosis of the receptor [63].

MicroRNAs (miRNAs), small noncoding RNAs, classically 20-22 nucleotides long, can regulate gene expression by repression of transcription and translation [68]. FGFR1 increases expression of miR-214-3p in an ERK1/2-activation-dependent manner, which subsequently downregulates expression of FGFR1 [69]. A complex feedback loop also exists between the miR-15/16 subfamily of miRNAs and FGF/FGFR signaling. FGFR activation negatively regulates expression of miR-15/16 subfamily members miR-15a, miR-15b and miR-16. This reduces miR-15/16-mediated transcriptional-repression of both FGFs and FGFRs [70]. miRNA downregulation of FGFR expression has been studied in relation to cancer progression but not necessarily as part of a feedback mechanism of FGFR activation. Expression of FGFR1 targeting miR-214 is decreased in a subset of HCCs, which is associated with increased FGFR1 expression [71]. Other examples include miR133b direct downregulation of FGFR1 expression and RAS-MAPK/PI3K-AKT signaling in osteosarcoma cells [72], miR-889-3p decreasing FGFR2 expression in cervical cancer [73] and miR-24-3p downregulation of FGFR3 expression in multiple myeloma (MM) and lung adenocarcinoma [74].

SPROUTY (SPRY) proteins are also negative regulators of RTK signaling. SPRY1/2 dissociates from GRB2 following PTPN11-mediated dephosphorylation, facilitating the GRB2-FRS2 interaction downstream of FGFR activation. SPRY1/2/4 are considered tumor suppressors for their negative regulation of RAS-MAPK activity [75,76]. SPRY Y55 phosphorylation is required for SPRY interaction with E3-ubiqutin ligase CBL and serine/threonine protein phosphatase 2A (PP2A) (Figure 2), and inhibition of RAS-MAPK signaling [77-80]. These SPRY actions are dependent on FRS2 and SFK activity downstream of FGF2 [81,82]. Other negative regulators of FGFR signaling include protein tyrosine phosphatase receptor type G (PTPRG), which colocalizes with and suppresses FGFR1 activity at the plasma membrane [83], and dual specificity phosphatase 6 (DUSP6, often referred to as MKP3) which represses FGFR activity [84].

Growth-factor receptor bound 14 (GRB14) is recruited to the PLC $\gamma$ binding site; the phosphorylated Y766 of FGFR1. As an FGFR1-PLC $\gamma$-GRB14 complex, GRB14 inhibits PLC $\gamma$ phosphorylation by FGFR1 and subsequent downstream PLC $\gamma$-signaling events (Figure 2) [85-87]. The activity of GRB14 bound to FGFR1 has also been shown to block activation of ERK1/2, MAPK8 (also known as JNK1) and AKT signaling [86].

The E3-ubiquitin ligase CBL recognizes consensus sequences containing tyrosine phosphorylation to bind target proteins. Following binding, CBL catalyzes mono and polyubiquitination of the target protein, which is predominantly associated with promoting either lysosomal or proteasomal degradation [88]. CBL is recruited to the FGFR-FRS2GRB2 complex, where it binds GRB2 and ubiquitinates FRS2 and FGFR (Figure 2) [89]. Interactions with PI3K increase following FGFR2 activation, which attenuates PI3K-AKT signaling in osteoblasts [90]. Ubiquitination of FGFR following activation is required for sorting of the receptor into the lysosome for degradation to regulate FGFR signal duration. Mutation of lysine residues within the intracellular domain of FGFR to prevent ubiquitination promotes sorting of FGFR into the recycling endosome [91].

Ligand-dependent signaling is, in part, regulated by differential trafficking of the receptor isoforms. FGF1 activation of FGFR1-3 IgIIIc isoforms causes rapid sorting of the receptors into late endosomes/lysosomes, most rapidly FGFR1-IgIIIc, while FGFR4 is sorted to the recycling compartment [92]. Similarly, FGF7 induces degradation of FGFR2IgIIIb through recruitment of CBL and increased ubiquitination of the receptor, giving rise to transient ERK1/2 activation. Alternatively, FGF10-mediated autophosphorylation of 
Y734 recruits PI3KR1/2 and SH3 binding protein 4 (SH3BP4), which instead results in sorting to the recycling compartment, sustained ERK1/2 activation and higher mitogenic activity [42,93].

In conclusion, FGF/FGFR signaling requires tight regulation through different mechanisms, and this regulation is often lost in cancer.

\section{FGF Signaling Diversity in Cancer}

Seven families of FGF have been characterized based on expression, receptor-specificity and downstream signaling axis similarities. A total of $22 F G F$ genes gives rise to seven subfamilies: FGF1, FGF4, FGF7, FGF8, FGF9, FGF15/19 and intracellular FGF (iFGF) [3] (Figure 1C). FGF oncogenic signaling primarily occurs through FGFR1-4 amplification, translocation and/or increased expression, and very rarely have mutations in FGF genes been associated with oncogenic signaling [3]. Despite this, autocrine, paracrine and endocrine FGF signaling have been implicated in cancer [94]. In the following sections we discuss the diversity of roles of FGF subfamilies and their receptors in several cancer types through illustrative examples (Tables 1 and 2), highlighting intrinsic differences in FGFR biology that contribute to a complicated network of FGF-FGFR signaling in cancer.

Table 1. Examples of cancer types where expression of Fibroblast Growth Factor (FGF) subfamily members regulate oncogenic processes.

\begin{tabular}{|c|c|c|}
\hline FGF Subfamily & Cancer Type & Associated References \\
\hline \multirow{6}{*}{ FGF1 } & Bladder & [95] \\
\hline & Breast & [96] \\
\hline & Melanoma & [97] \\
\hline & Ovarian & [98] \\
\hline & Pancreatic ductal & [99] \\
\hline & $\begin{array}{c}\text { adenocarcinoma } \\
\text { Small cell lung cancer }\end{array}$ & {$[100]$} \\
\hline \multirow{3}{*}{ FGF4 } & Bone & {$[101]$} \\
\hline & Gastrointestinal & {$[102,103]$} \\
\hline & Glioma & {$[104]$} \\
\hline \multirow{4}{*}{ FGF7 } & Breast & [42] \\
\hline & Gastric & {$[105]$} \\
\hline & Non-small cell lung cancer & {$[106,107]$} \\
\hline & $\begin{array}{l}\text { Pancreatic ductal } \\
\text { adenocarcinoma }\end{array}$ & {$[108]$} \\
\hline \multirow{5}{*}{ FGF8 } & Colorectal & [109] \\
\hline & Hepatocellular carcinoma & [110] \\
\hline & Head and neck & [111] \\
\hline & Prostate & [112] \\
\hline & Renal cell carcinoma & [113] \\
\hline \multirow{3}{*}{ FGF9 } & Colorectal & [114] \\
\hline & Hepatocellular carcinoma & [115] \\
\hline & Prostate & {$[116,117]$} \\
\hline \multirow{4}{*}{ FGF15/19 } & Colorectal & [118] \\
\hline & Endometrial & [119] \\
\hline & Hepatocellular carcinoma & {$[120]$} \\
\hline & Prostate & [121] \\
\hline \multirow{3}{*}{ iFGFs } & Colorectal & {$[122]$} \\
\hline & Prostate & {$[123,124]$} \\
\hline & Triple negative breast cancer & {$[125]$} \\
\hline
\end{tabular}

FGF, fibroblast growth factor; iFGFs, intracellular FGFs. 


\subsection{The FGF1 Subfamily}

The FGF1 subfamily includes secreted ligands FGF1 and FGF2, which both lack an $\mathrm{N}$-terminal classical-secretion signal peptide [126]. These alternative routes of secretion are considered a mechanism of preventing aberrant FGF1 and FGF2 signaling [127]. The FGF1 subfamily, as well as the FGF4, FGF7, FGF8 and FGF9 subfamilies, require the presence of the coreceptor HSPG, a transmembrane proteoglycan that binds FGFs and stabilizes FGF-FGFR interactions to regulate downstream signaling events [128-132]. FGF1 and FGF2 have promiscuity in receptor specificity in common; however, only FGF1 has been shown to bind all receptor isoforms (Figure 1C) [3]. With respect to genomic aberrations in the FGF1 subfamily, a study investigating SNPs and risk of breast cancer found that, on their own, SNPs in FGF1 and FGF2 were not associated with increased risk, but an FGF1 SNP was associated with decreased survival [133]. FGF1 amplification in ovarian cancer has been associated with promoting angiogenesis, reduced disease-free progression and overall survival [134,135]. FGF1 expression in ovarian cancer is associated with chemotherapy resistance. FGF1 can reduce the transcriptional activity of p53 and increase expression of p21 and subsequent antiapoptotic activity in response to ovarian cancer therapies etoposide and cisplatin [98]. FGF1 expression and secretion are increased in ovarian cancer associated fibroblasts (CAFs), which, when cultured with the SKOV3 human ovarian cancer cell line, increases ERK1/2 activity through activation of FGFR4. This activity increased expression of all markers for epithelial mesenchymal transition (EMT), the process of cellular reprogramming whereby epithelial cells remove cell-cell and basement membrane contacts, and transition to a mesenchymal phenotype [136]. EMT is considered crucial for cancer cell invasion, migration and metastasis [137]. Similarly, CAF secretion of FGF2 in breast cancer can bypass classical hormone receptor signaling inhibited by endocrine therapy to activate ERK1/2 signaling, promote MYC target gene expression and tumor growth. This suggests FGF2 secretion by CAFs has a role in endocrine therapy resistance in hormone receptor-positive breast cancer [138-140]. FGF2 is also overexpressed in subtypes of bladder cancer, and is associated with promoting migration, angiogenesis and invasiveness [141,142]. FGF2 expression by tumor vasculature pericytes has also been identified as a mechanism of anti-vascular endothelial growth factor receptor (VEGFR) resistance [143]. FGF2 is an angiogenic factor in multiple myeloma (MM) that positively regulates expression of growth and survival interleukin-6 (IL-6) in a reciprocal manner [144]. The use of FGF traps as inhibitors of FGF/FGFR signaling in MM cells has shown the FGF/FGFR signaling axis is required for stabilization of the oncoprotein, transcription factor c-MYC and subsequent resistance to mitochondrial oxidative stress induced apoptosis, which is critical in tumor progression $[145,146]$. Nuclear activity of a heavy molecular weight FGF2 (hmwFGF2) [147] has been implicated in promoting cell proliferation and survival in glioma $[148,149]$, in glioma cells, and indirectly through nuclear localization in astrocytes [149]. It is likely that nuclear hmwFGF2 induces this effect partly through decreased expression of tumor suppressor phosphatase and tensin homolog (PTEN), as well as increased AKT activity [148]. Low molecular weight (lmw) FGF2-FGFR1 colocalization in the nucleus, and subsequent activity in pancreatic stellate cells (PSCs), promotes proliferation and PSC-mediated pancreatic cancer cell invasion [150]. Recently a pro-survival role for nuclear lmwFGF2 has been characterized, whereby FGF2 colocalizes in the nucleus with apoptosis inhibitor 5 (API5) to promote mRNA export of cyclin D1 and c-MYC [151].

\subsection{The FGF4 Subfamily}

The FGF4 subfamily contains FGF4, FGF5 and FGF6, which have common receptorbinding affinities, binding the mesenchymal FGFR1-3-IgIIIc isoforms as well as FGFR4 (Figure 1C) [152]. An N-terminal signal peptide regulates secretion of the FGF4 subfamily through ER-Golgi entry [153]. Amplification of the 11q13 amplicon, present in breast cancer, results in co-amplification of FGF3, FGF4 and FGF19 [154], but is also observed in other cancer types [155]. In the presence of CAFs, expression of FGF4 and FGFR2 is 
increased in cancer stem cells isolated from the ovarian cancer cell line HTBoA. Cancer stem cells are commonly referred to as cancer initiating cells for their tumorigenic activity associated with resistance to therapy, increased recurrence and metastasis. FGF4 expression in these cancer stem cells increased sphere-formation, which could be reduced by silencing of FGFR2 [156]. In molecular subtypes of gastrointestinal stromal tumors (GISTs), which lack any of four common biomarkers referred to as quadruple WT GIST, FGF4 amplification and increased expression resulted in increased AKT activation downstream of FGFR1, and has been suggested as a therapeutic target in this molecular subtype [102].

\subsection{The FGF7 Subfamily}

The FGF7 subfamily, which comprises FGF3, FGF7, FGF10 and FGF22, is expressed in mesenchymal cells and shows high affinity for epithelial FGFR2-IgIIIb binding, less so for FGFR1-IgIIIb, and none for FGFR3-IgIIIb [152,157]. This high-specificity of FGF7 subfamily members is partly underpinned by hydrogen bonds, dependent on the unique aspartic acid residue D76 present in FGF7, but not FGF10, within an interaction site with serine 315 of FGFR2-IgIIIb [158]. Despite this unanimous subfamily specificity, gene knockout studies show that the roles of these four family members are nonredundant [159]. In human gastric cancer cells, FGF7-FGFR2 signaling increased PI3K-AKT-mTOR signaling, which upregulated invasive/migratory glycoprotein thrombospondin 1 (THBS1). This FGF7FGFR2-THBS1 activity increases migration and invasion of gastric cancer cells [105]. FGF10FGFR2b signaling promotes migration of breast cancer and pancreatic adenocarcinoma (PDAC) cells $[42,108,160]$. FGF10 is expressed in PDAC stromal cells, while FGFR2 is expressed in cancer cells and is associated with poor prognosis [108]

\subsection{The FGF8 Subfamily}

FGF8, FGF17 and FGF18 belong to the secreted FGF8 subfamily, which shows the highest affinity for the FGFR3-IgIIIc isoform and an FGFR4 isoform with two Ig-domains [157]. A property of FGF8 subfamily ligands is regulation of isoform expression by alternative splicing. Alternative splicing of $F G F 8$ gives rise to four isoforms, FGF8a/b/e/f, which have divergent roles in development [161]. FGF8 expression has been linked to neoadjuvant radiochemotherapy resistance in colorectal cancer (CRC). The level of FGF8 detected by immunohistochemistry was increased in nonresponsive patient samples in comparison to responsive patients. This was associated with increased expression of survivin (BIRC5), which is an inhibitor of apoptosis. Exposure of CRC cell lines to radiation increased expression of FGF8 and FGFR3 in the surviving cell population [109].

\subsection{FGF9 Subfamily}

Like the FGF1 subfamily, FGF9, FGF16 and FGF20, which make up the FGF9 subfamily, do not have an N-terminal signal peptide implicated in ER-Golgi transport. Despite this, FGF9 is secreted via ER-Golgi-mediated transport [162-164] using an alternative secretion signal dependent on two hydrophobic regions located centrally and N-terminally $[165,166]$. FGF9 has been implicated in crosstalk between HCC cells and hepatic stellate cells, which promotes liver fibrosis and tumor progression. FGF9 is expressed by hepatic stellate cells, which signals to HCC cells in a paracrine manner to activate ERK1/2 and JNK signaling, promote migration and proliferation. Furthermore, stimulation of HCC cells with FGF9 reduced sensitivity to the HCC therapy sorafenib [115].

\subsection{FGF15/19 Subfamily}

The FGF15/19 subfamily, commonly referred to as the endocrine FGFs, consists of FGF19 (human ortholog of mouse FGF15), FGF21 and FGF23, which have an endocrine function regulated by the FGFR coreceptor Klotho [3]. Klotho directly interacts with a conserved C-terminal sequence of FGF15/19 subfamily ligands to coordinate binding with FGFR and to activate signaling [167]. Different Klotho species regulate the affinity of FGFRs for FGF ligands. For example, Klotho- $\beta(K L B)$ is required for FGF21 activation of 
FGFR1 and FGFR3-IgIIIc isoforms, whereas FGF23 requires Klotho- $\alpha(K L)$ [168]. Genomic aberrations in the FGF19 subfamily members have rarely been associated with a role in cancer progression, with the exception of an SNP in FGF23 that has been linked to increased risk of prostate cancer [169]. Although not directly linked to the SNP, FGF23 overexpression has also been associated with reduced overall survival and shortened time to occurrence of bone metastases [170] A large proportion of endometrial cancers are associated with metabolic disorders, including obesity. FGF21 and FGF23 expression have been implicated in endometrial cancer due to their association with increased expression of leptin (LEP), a hormone produced in adipose tissue. Serum FGF21 and LEP concentrations are increased in patients with endometrial cancer, and associated with low differentiation and higher grade of tumor [119]. Circulating FGF21 has also been associated with increased risk of CRC [118].

\subsection{Intracellular FGFs}

The intracellular FGFs (iFGFs), or fibroblast homologous factors (FHFs), family includes FGF11-14 (or FHF1-4), a subfamily of FGFs with no signal sequence that are not secreted and instead are considered cytosolic growth factors [171]. Traditionally, this subfamily has been considered to function independently of FGFR, instead binding to islet brain-2 (IB2) and sodium channels [172,173]. However, recent studies have shown that exogenous iFGFs can activate signaling. Treatment of cells with FGF11 and FGF13 can activate signaling cascades [174,175] and, in the case of FGF11, can initiate antiapoptotic processes and bind all four FGFRs to activate signaling when ectopically expressed [174]. Given that a mechanism of iFGF secretion has not been described, the physiological role of iFGFs in activating FGFR remains to be elucidated. Despite this, iFGFs have known functions in promoting tumor progression. FGF11-miR-541 activity in response to T-cell infiltration in prostate cancer contributes to prostate cancer cell invasion, likely through suppression of androgen receptor and matrix metallopeptidase 9 (MMP9) activity [123]. A recent study focused on the role of FGF13 expression in triple negative breast cancer (TNBC) (ER-, progesterone receptor-, and human epidermal growth factor receptor 2 (HER2/ERBB2)-negative breast cancer), an aggressive subtype of breast cancer where FGF13 expression was associated with relapse but was not increased in primary breast tumors. In a highly metastatic variant of human TNBC cell line MDA-MB-231, suppression of FGF13 removed almost all ability to metastasize to liver and lung, suggesting FGF13 has a role in determining a subset of TNBC's propensity for metastasis to specific sites [125]. FGF14 expression, on the other hand, has been associated with tumor suppressor activity, which is downregulated in CRC tumor samples and in CRC cell lines as a result of high methylation of FGF14. Restoring FGF14 expression significantly reduces CRC tumor growth in vivo, associated with downregulation of PI3K-AKT-mTOR signaling in vitro [122].

\section{FGFR Genomic Aberrations in Cancer}

Perturbed FGFR signaling has been implicated across cancer subtypes in both cancer development and progression. Mechanisms of FGFR1-4-mediated oncogenic signaling include amplifications and/or overexpression, missense mutations, translocations and, in some cancer subtypes, loss of FGFR1-4 expression. Cancer types with known FGFR1-4 aberrations are summarized in Table 2. 
Table 2. Examples of cancer subtypes for which Fibroblast Growth Factor Receptor (FGFR) genetic aberrations have been identified.

\begin{tabular}{ccc}
\hline FGFR Gene & Cancer Subtype & Associated References \\
\hline & Breast cancer & {$[10,176,177]$} \\
& Colorectal cancer & {$[178,179]$} \\
& Gastrointestinal & {$[180]$} \\
& Glioma & {$[181,182]$} \\
Head and neck & {$[183]$} \\
FGFR1 & Non-small cell lung cancer & {$[184-188]$} \\
& Ovarian cancer & {$[189]$} \\
& Pancreatic ductal adenocarcinoma & {$[190]$} \\
& Prostate cancer & {$[191-194]$} \\
& Small cell lung cancer & {$[186,195-197]$} \\
& Urothelial cancer & {$[189]$} \\
\hline \multirow{2}{*}{ FGFR2 } & Breast cancer & {$[10,198]$} \\
& Cholangiocarcinoma & {$[199-201]$} \\
& Endometrial cancer & {$[202]$} \\
& Gastric cancer & {$[9,203,204]$} \\
& Non-small cell lung cancer & {$[205]$} \\
\hline \multirow{2}{*}{ FGFR3 } & Bladder cancer & {$[189,206-214]$} \\
& Cervical cancer & {$[209,215,216]$} \\
& Glioma & {$[181,189]$} \\
\multirow{2}{*}{ FGFR4 } & Non-small cell lung cancer & {$[189,205,217,218]$} \\
& Adrenocortical cancers & {$[219]$} \\
& Breast cancer & {$[189]$} \\
\hline
\end{tabular}

\subsection{FGFR1}

Amplifications are the most common FGFR1-4 genomic aberrations. Analysis of 4873 cancers found $61 \%$ of FGFR $1-4$ aberrations (7.1\% of all cancers) were amplifications. FGFR 1 amplifications accounted for approximately $41 \%$ of all FGFR1-4 genomic aberrations [189]. Amplifications in FGFR1 (8p11) are most commonly present in squamous cell carcinoma [184], more common than other non-small cell carcinomas and associated with late-stage [185], but not necessarily with poor prognosis [220,221]. In non-small cell lung cancer (NSCLC), FGFR1 amplification is detected at a rate of $6 \%(n=63)$ [186]. Inhibition of FGF/FGFR1 signaling in NSCLC has shown that the FGF/FGFR1 signaling axis promotes survival and resistance to oxidative stress in an MYC-dependent manner [222]. Analysis of 1875 breast tumor samples showed that FGFR1 8p11-12 amplification occurs in 10.5\% of breast cancers, associated with estrogen receptor (ER) expression and lobular breast cancer [176], and in $8.9 \%$ of a cohort of 595 breast cancer tumors [177]. FGFR1 amplifications in breast cancer are associated with lower rates of five-year disease-free survival, overall-survival and resistance to endocrine therapy [176,223-225]. Genetic analysis of 38 paired hormone sensitive and post-hormone resistant tumors found that $47 \%$ of all tumors had amplification of FGFR1 or FGFR2 (most common). None of the pre-hormonesensitive tumors had FGFR1 amplification; however, $17.65 \%$ of the post-hormone-resistant tumors had FGFR1 amplification [226]. Moreover, FGFR1 amplification has been implicated in resistance to hormone receptor therapies [223]. Other cancers with amplification of FGFR1 genes include FGFR1 in pancreatic adenocarcinoma (PDAC) [190], likely expressing the FGFR1-IgIIIc isoform $[227,228]$, with FGFR1 amplification in ovarian and urothelial cancer [189].

\subsection{FGFR2}

FGFR2 amplifications are the second most common amplifications of FGFR1-4 in cancer [189]. Interestingly, in the aggressive TNBC subtype, only FGFR2 amplification (10q26) and overexpression are detected, occurring in $4 \%$ of tumors [10]. FGFR2 amplification is 
also prominent in gastric cancer. A large multicenter study found FGFR2 amplification in $7.4,4.6$ and $4.2 \%$ of gastric cancers from patients in the United Kingdom, China and Korea ( $n=961)$ [203]. A similar rate of $4.1 \%$ was found in a smaller study of 267 gastric cancers, which showed conferred sensitivity to FGFR inhibition in gastric cancer cell lines [9]. In 1045 patients with metastatic gastroesophageal cancer, FGFR2 amplification was identified in $4 \%$ of patients [229].

Mutations in FGFR are considerably less common than amplification, accounting for $26 \%$ of FGFR aberrations in cancer. Mutations in FGFR2 and FGFR3 were the most common [189]. Of the unique mutations identified for each receptor, all that had been characterized, and the majority that have since been characterized, are known to be activating mutations, and some have known transforming activity. FGFR2 mutations are most common in endometrioid cancers and gastric cancers [204]. In endometrioid cancers, the majority of FGFR2 mutations are known to have activating potential [202]. SNPs in the FGFR2 gene are also associated with increased risk of breast cancer [198].

Fusion proteins arise from chromosomal translocations that result in fusion of two genes. In the case of the FGFR family, the most common fusion proteins include FGFR3 and FGFR2 [189]. Fusions involving FGFR1 and FGFR4 are rare [230]. Fusions containing FGFR2 are most common in cholangiocarcinoma [199-201]. These fusions do not show a preference for a partner as do FGFR3 fusions. The most common FGFR2 fusions in cholangiocarcinoma are with the BicC family RNA binding protein 1 (BICC1), the sickle tail protein homolog (KIAA1217), S-adenosylhomocysteine hydrolase-like protein 1 (AHCYL1) and the coiled-coil domain containing protein 6 (CCDC6) [199,200]; however, more than 100 other fusion partners have been identified. The biological implications of the majority of FGFR2 fusions have not been described [230]. FGFR2-BICC1 and FGFR2-AHCYL1 fusions have been shown to promote tumorigenesis in vivo, likely resulting in constitutive FGFR2 kinase activation, promoting anchorage-independent growth [231].

\subsection{FGFR3}

FGFR3 and FGFR4 amplifications are less common and less well studied than FGFR1 and FGFR2 amplifications. FGFR 3 amplification is the most common FGFR amplification event in urothelial/bladder cancer [189,206-208].

FGFR3 mutations are the most common FGFR aberration in urothelial cancers and lung squamous cell cancer [189], and are common in cervical and bladder carcinomas. Analysis of 25 FGFR3 mutations, either identified in cancer or corresponding to common mutations in FGFR1/2/4, revealed that the two most common mutations, K650E and N540K, cause large increases in activation of the receptor, whereas less common substitutions at the same sites have less of a pronounced effect on activation. Twelve sites had no notable effect and two resulted in loss of activation. Conflict in some results with previously published works, lead the authors to conclude that SNPs in FGFRs may have roles dependent on the cellular context [232].

Fusion of FGFR3 to transforming acidic coiled coil 3 (TACC3) is the most common FGFR fusion protein, which gives rise to a constitutively active FGFR3-TACC3 protein. FGFR3-TACC3 increases FGFR3-dependent signaling [181] and also utilizes TACC3's role in stabilizing microtubules during chromosome segregation in mitosis [233], which results in aneuploidy prominent in tumors [181]. FGFR1-TACC1 and FGFR3-TACC3 fusions are present in $3.1 \%$ of glioblastoma multiforme [181], an aggressive malignant primary brain tumor. FGFR3-TACC3 fusions are also present in other gliomas, urothelial cancers $[189,210,234]$, NSCLC $[217,218]$ and in cervical cancer $[215,216]$.

\subsection{FGFR4}

FGFR4 amplification is predominantly associated with breast $[189,234]$ and adrenocortical tumors [219], although it is likely that overexpression without amplification occurs more frequently. 
A germline FGFR4 mutation identified in breast cancer cell lines, SNP Glycine (G) 388 to Arginine (R) (G388R), was associated with increased FGFR4 expression. The heterozygous G388/R388 allele and homozygous R388/R388 allele were present at consistent frequencies, $42-49 \%$ and $6-11 \%$, respectively, in tumor samples from breast cancer and CRC patients. The homozygous and heterozygous alleles were associated with reduced disease-free survival in both cancer types, as well as lymph node metastasis in CRC [235]. A combined meta and pool analysis of 9354 FGFR4 G388 allele statuses in multiple cancer types found an association between G388R homo/heterozygosity and reduced overall survival [236]. More recently, a pool analysis of 13,793 cancer patients found the FGFR4 G388R allele to be associated with increased susceptibility of cancer, which when stratified by cancer type was associated with increased risk of breast and prostate cancer. This SNP was predicted to change protein function [237].

\subsection{FGFR5}

Despite being closely related to the FGFR family, the activity of FGFR5 has been likened more to the CAM Nectin [238,239]. FGFR5 predominantly forms homotrimers at the plasma membrane. However, when co-expressed with FGFR1, it forms heterotrimers (FGFR1:FGFR5:FGFR5) which dimerize downstream of FGF2 stimulation to form a complex of two FGFR1 molecules and four FGFR5 molecules [23]. The constitutive dimers are proposed to function as adhesion molecules, similar to Nectins [239], with no known influence on ERK1/2 signaling or proliferation [238]. FGFR5 is overexpressed in $10 \%$ of CRC cell lines; however, the oncogenic role of FGFR5 has not been characterized yet.

\section{The Role of Canonical FGFR Cofactors in Cancer}

\subsection{Heparan Sulfate Proteoglycans}

HSPGs exist as coreceptors for FGF-FGFR signaling [128]. Additionally, ligandspecificity and subsequent downstream signaling are differentially regulated by the HSGAG side chains attached to the HSPG core domain [240].

The expression of syndecan, a transmembrane HSPG, has been implicated in angiogenesis and lymphangiogenesis in ductal breast carcinoma [241], and in mediating FGFR signaling in breast carcinomas [242]. At the ligand-binding level, syndecans differentially regulate FGFR signaling. Regulating the HS chains of syndecan-1 has been suggested to promote malignancy in premalignant tumor epithelial cells through regulation of FGF binding activity [243]. In lymphoma cells, syndecan-1 can regulate binding of FGF1 and FGF2, but only increases FGF2-dependent signaling [244]. Colocalization of FGF2 in the nucleus and FGFR1 in the perinuclear region of mesenchymal tumor cells is dependent on co-translocation of syndecan-1 [245]. Glypican, a secreted HSPG, has also been implicated in mediating FGFR signaling in tumorigenesis. Glypican- 1 is expressed in glioma endothelial blood vessels, but undetectable in healthy brain endothelial blood vessels, and enhanced the mitogenic activity of FGF2-FGFR1-IgIIIc signaling [246].

\subsection{Klotho}

The Klotho family comprises three genes, KL, KLB and $L C T L$, which give rise to Klotho$\alpha$, Klotho- $\beta$ and Klotho- $\gamma$ (otherwise known as lactase like or klotho LPH-related protein) isoforms. These genes encode a single-pass transmembrane protein with large extracellular domain, a transmembrane helix and short intracellular C-terminal tail. Cleavage of Klotho family members gives rise to a secreted and soluble version. Klotho in cancer is generally associated with being a tumor suppressor [247].

The role of Klotho- $\beta$ in mediating FGFR-specific signaling has been mostly studied in the last decade, and has been associated with tumor-suppressor activity in breast cancer cell lines [248] and as a tumor promoter in urothelial carcinoma [168]. Klotho- $\beta$ has been shown to function as a "zip-code" for recruitment of endocrine FGF ligands to FGFR [249]. Klotho$\beta$ is required for increased FGF19-FGFR4 signaling in lung squamous cell carcinoma, to promote cell growth, tumor progression and metastasis, possibly through increased FGF19- 
FGFR4-mTOR signaling [250]. Klotho- $\beta$ expression as a coreceptor for FGFR4 has also been implicated in HCC [251], increasing FGF15/19-dependent activity to promote EMT, migration and WNT/ $\beta$-catenin signaling [252]. This activity has been associated with early tumor reoccurrence [253]. Half of phosphaturic mesenchymal tumors lack FGFR1 fusions; however, Klotho- $\beta$ overexpression in this subset has suggested that in the absence of FGFR1 fusion, FGFR signaling is still active through Klotho- $\beta$ [254]. The FGF-FGFR signaling axis has a role in promoting EMT in MM [255]. In MM cells, Klotho- $\beta$ is expressed alongside elevated FGF23, where an FGF23-Klotho- $\beta$-heparanase signaling axis has been implicated in increasing migration and invasion and in metastasis formation [256]. Alternatively, loss of Klotho- $\beta$ activity has been associated with prostate cancer progression, where decreased expression increases EMT, growth and ERK1/2 signaling [257]. Less established is the role of Klotho- $\gamma$ in mediating FGFR signaling in cancer. It has been proposed as a biomarker in TNBC, where Klotho- $\gamma$ is required for survival, and its silencing results in constitutive ERK activation in the absence of a ligand [258].

\section{Noncanonical Regulators of FGFR Signaling in Cancer}

The non-canonical signaling partners of FGFR include extracellular matrux (ECM)associated, cell adhesion molecules (CAMs), RTKs, other transmembrane proteins and serine/threonine kinases. Such heterotypic interactors and regulators of FGFR signaling have been described in a wide range of cancers for all FGFRs (summarized in Table 3).

Table 3. A summary of noncanonical interaction partners of FGFR1-4 which have been linked to cancer.

\begin{tabular}{|c|c|c|c|c|}
\hline FGFR & Partner & Cancer Subtype & Consequence of Interaction & Associated References \\
\hline \multirow{14}{*}{ FGFR1 } & Anosmin-1 & Brain; Glioblastoma & Promotes motility and invasion in FGFR-dependent manner & [259] \\
\hline & Collagen type IV & Pancreatic & Sustained ERK1/2 activation & {$[10,176,177,260]$} \\
\hline & EGFR & Lung & Increases AKT and STAT3 signaling & [261] \\
\hline & EPHA4 & Glioma & Potentiates FGFR1-signaling & [262] \\
\hline & Galectin-1 & Osteosarcoma & Activated FGFR1, increased proliferation and survival & [263] \\
\hline & Galectin-3 & Osteosarcoma & FGFR1 plasma membrane clustering & [263] \\
\hline & GALNT14 & Breast & Promotes FGFR activation & [264] \\
\hline & Integrin- $\alpha \mathrm{V} \beta 3$ & Breast & Increased tumorigensis, angiogenesis and EMT & {$[265,266]$} \\
\hline & Integrin- $\beta 3$ & Breast & Disrupts colocalization with E-cadherin and promotes EMT & [267] \\
\hline & L1CAM & Glioma & Promote motility and proliferation & {$[268,269]$} \\
\hline & N-cadherin & Breast & $\begin{array}{l}\text { Stabilizes FGFR1 at plasma membrane, promoting sustained } \\
\text { ERK1/2 signal, increased invasion, motility and metastasis }\end{array}$ & {$[270,271]$} \\
\hline & NRP1 & Breast & FGFR1-NRP1 complex increases during EMT & [272] \\
\hline & RET-KIF5B, EGFR & $\begin{array}{l}\text { RET-KIF5B fusion } \\
\text { positive cancers }\end{array}$ & $\begin{array}{l}\text { Increases FGFR activation and promotes inavdopodia } \\
\text { formation }\end{array}$ & [273] \\
\hline & TGFBR3 & Neuroblastoma & $\begin{array}{l}\text { Activates ERK1/2 signaling, promoting differentiation, } \\
\text { suppressing tumor growth and metastasis }\end{array}$ & {$[274]$} \\
\hline \multirow{3}{*}{ FGFR2 } & EGFR & Breast & $\begin{array}{l}\text { Induces EGFR T693 phosphorylation, recycling and } \\
\text { stabilization and increases cell cycle outputs }\end{array}$ & [275] \\
\hline & EPHA4 & Glioma & Increases proliferation and migration & [262] \\
\hline & RET-KIF5B, EGFR & $\begin{array}{l}\text { RET-KIF5B fusion } \\
\text { positive cancers }\end{array}$ & $\begin{array}{l}\text { Increases FGFR activation and promotes inavdopodia } \\
\text { formation }\end{array}$ & {$[273]$} \\
\hline \multirow{2}{*}{ FGFR3 } & PYK2 & Multiple myeloma & Increases STAT5 activation & [276] \\
\hline & TAK1 & $\begin{array}{l}\text { Multiple } \\
\text { myelomaBladder }\end{array}$ & Cell adhesion and NFKB-dependent transcription & {$[277]$} \\
\hline \multirow{2}{*}{ FGFR4 } & NCAM & Pancreatic & Promote neurite outgrowth & [278] \\
\hline & NCAM & Pituitary neoplasia & When interaction is inhibited increases invasive phenotype & [279] \\
\hline
\end{tabular}

EGFR, epidermal growth factor receptor; EMT, epithelial-mesenchymal transition; EPHA4, ephrin type A receptor 4; ERK1/2, extracellular signal-regulated protein kinase 1/2; FGFR, fibroblast growth factor receptor; L1CAM, L1 cell adhesion molecule; GALNT14, polypeptide $\mathrm{N}$-acetyl galactosaminyltransferase 14; NFkB, nuclear factor $\kappa \mathrm{B}$; NRP1, neuropilin 1; PYK2, focal adhesion nonreceptor protein tyrosine kinase 2; RET-KIF5B, rearranged during transfection (RET)-kinesin family member 5B (KIF5B); STAT3/5; signal transducer and activator of transcription 3/5; TAK1, transforming growth factor $\alpha$-activated kinase 1 ; TGFBR3, transforming growth factor receptor $\beta$; T693, threonine 693. 


\subsection{ECM-Associated Signaling Partners}

FGFR interactions with extracellular matrix (ECM) proteins have been shown to regulate FGFR signaling outputs with possible implications for tumorigenesis. Collagen is laid by tumor cells to form an integral component of the tumor microenvironment, where it regulates processes associated with cancer progression, in particular metastasis [280]. Collagen type IV-mediated upregulation of FGFR1 expression in pancreatic $\beta$-cells results in FGFR1-dependent sustained ERK1/2 activation [260]. A more direct interaction has been demonstrated for fibronectin, an ECM glycoprotein largely activated through interactions with integrins. Fibronectin is critical for assembly of the tumor microenvironment, and has known roles in promoting invasion and metastasis, as well as regulating signaling events required for tumor progression [281]. Fibronectin can directly activate FGFR1 by inducing SRC-/integrin- $\beta 1$-dependent phosphorylation of Y653, Y654 and Y766, promoting an AKTsignaling response over an ERK1/2-signaling response. This, in turn, induces chemotaxis and promotes migration in endothelial cells [282]. More recently, a novel interaction was identified between FGFR1 and galectin-1 (LGALS1)/galectin-3 (LGALS3) in osteosarcoma cells ectopically expressing FGFR1. Galectins are predominantly extracellular glycan binding proteins which are expressed in tumors, with roles in promoting angiogenesis and immune evasion in tumor progression [283]. These interactions are mediated by sugar chains at specific glycosylation sites on the extracellular surface of FGFR1 but result in a galectin-dependent response. LGALS3-FGFR1 interactions altered FGFR1 trafficking, causing FGFR1 to cluster at the plasma membrane and not be internalized. LGALS1 on the other hand activated FGFR1 to elicit more canonical signaling, with a proliferative and survival effect [263]. Given the independent roles of FGFR1 and galectins in cancer, we suggest that galectins could be of relevance when considering targeted therapies regulation of FGFR1 signaling.

Integrins are a family of cell-surface receptors which, in cancer, are predominantly associated with promoting tumor cell migration and invasion through interactions and remodeling of the ECM [284]. Integrin-regulated FGFR signaling has been directly implicated in tumorigenesis, particularly in angiogenesis, a critical step during the formation of metastasis. FGF1-Integrin- $\alpha$ V $\beta 3$-FGFR1 crosstalk has been shown to promote angiogenesis and tumorigenesis [265], and later shown to enhance EMT in breast cancer cell lines [266]. Integrin $\alpha \mathrm{V} \beta 3$ differentially regulates FGF1-dependent signaling to promote changes in cellular outputs, including DNA synthesis, proliferation, chemotaxis and migration [285]. FGFR-integrin crosstalk is not limited to Integrin- $\alpha V \beta 3$ in breast cancer. Integrin- $\beta 3$ is required for FGF2-dependent signal induction in a mouse metastatic breast cancer model, which disrupts FGFR colocalization with epithelial marker E-cadherin in a focal adhesion kinase (FAK)-activation dependent manner to promote EMT [267]. In melanoma cells, an osteopontin-integrin $\alpha \mathrm{V} \beta 3$ crosstalk has been implicated in mediating FGF2-driven survival [286]. Integrin- $\beta 4$ signaling in cancer has been associated with promoting tumor progression, and has been suggested as a candidate for immunotherapy in highly metastatic cancers [287]. Integrin- $\beta 4$ antiapoptotic activity was shown to be down-regulated by FGF2-FGFR1-dependent phosphorylation of Integrin- $\beta 4$ Y1494 and nuclear translocation [288].

Anosmin-1 (ANOS1, previously the KAL1 gene) is an ECM-associated transmembrane glycoprotein which is able to directly interact with FGFR1 in a complex with HSPG and FGF2 [289]. The ANOS-FGFR signaling axis is often studied in relation to its role in Kallman Syndrome, a developmental disorder predominantly associated with hearing loss and Hypogonadotropic Hypogonadism. The signaling axis differentially regulates ERK1/2 and PI3K signaling downstream of FGFR activation in a cell-type dependent manner [290]. A role for ANOS1-FGFR1 signaling has been indicated by increased expression of ANOS1 in high grade brain tumors when compared to healthy or low-grade brain tumors. In the presence of Integrin $\beta 1$, ANOS1 promotes motility and invasion in glioblastoma cell lines, which are FGFR inhibition sensitive. ANOS1 activity likely elicits its migratory/invasive activity by activating ECM proteases and modulating cell adhesion [259]. 


\subsection{Cell Adhesion Molecules}

CAMs have been implicated in promoting migratory properties associated with EMT in cancer. Several CAMs are glycoproteins belonging to the immunoglobulin superfamily (IgSF), one of the largest protein families, which typically have at least one extracellular Ig domain, a single-pass transmembrane domain and a cytoplasmic tail. IgSF CAMs exert their adhesive action through homophilic interactions between IgSF CAMs on opposing cell surfaces, and heterophilic interactions with other cell surface adhesion molecules or proteins on opposing cell surfaces or in the ECM [291]. Neural-CAM (NCAM) can activate FGFR1 independently of FGF-mediated activation, which regulates trafficking and SFK-signaling in a cell type-dependent manner [292]. In pancreatic tumor $\beta$-cell neurite outgrowth and adhesion to matrix, NCAM mediated the formation of a complex containing NCAM, FGFR4, FRS2, PLC $\gamma$, SRC, cortactin and GAP43. The FGF ligand alone could not promote neurite outgrowth, which was dependent on FGF-integrin- $\beta 1$ signaling [278]. Recently, an NCAM-FGFR1 signaling axis was identified downstream of transforming growth factor $\beta$ (TGF $\beta$ ), that promotes transforming growth factor $\beta$ (TGF $\beta$ )driven EMT of human proximal tubular epithelial cells [293]. NCAM is also associated with negatively regulating tumor progression. A pituitary tumor-derived FGFR4 (ptdFGFR4) isoform has an alternatively transcribed $\mathrm{N}$-terminal truncated cytoplasmic tail, which can no longer associate with NCAM. NCAM-dependent signaling and adhesion are reduced, generating a ptdFGFR4-mediated invasive phenotype in pituitary neoplasia [279]. A different member of the IgSF, L1CAM, signals through FGFR1 in glioma to promote motility and proliferation [268]. Inhibiting FGFR, integrin or FAK signaling depletes the L1CAM response in L1CAM-positive glioblastoma cells, suggesting an L1CAM-FGFR-integrin-FAK signaling axis is required for L1CAM driven motility and proliferation [269].

Cadherins, a family of transmembrane glycoproteins, form complexes with intracellular membrane-localized catenins to activate signaling pathways and regulate cell-cell contacts, which are implicated in processes involved in tumor initiation and progression [294]. FGFR interacts directly with cadherins (and NCAMs) through the conserved acid-box region in IgIII [295]. The role of FGFR-cadherin interactions is dependent on the type of cadherin, giving rise to a role for FGFR-cadherin signaling as tumorigenic and tumor suppressive. [296,297]. N-cadherin can stabilize FGFR1 at the plasma membrane, preventing ligand-dependent internalization and degradation [270], which in turn enhances a sustained ERK1/2 signal, increases transcription of MMP9 and promotes invasion. In mammary tumor development, the N-cadherin-FGFR-sustained ERK signal has been associated with motility, invasion and metastasis [271]. TGF $\beta$ was later shown to increase N-cadherin-dependent expression and signal regulation of FGFR1, which increased AKT signaling and promoted invasion independent of ERK1/2 signaling [298]. FGFR1/4 overexpression in lung cancer has been suggested as a biomarker for poor outcomes and FGFR-targeting therapy when co-expressed with N-cadherin [299]. Similar to N-cadherin, cadherin-11 forms a complex with FGFR and $\beta$-catenin to promote neurite outgrowth [300]. Alternatively, FGFR1 can directly interact with $\mathrm{N}$-cadherin at cell-cell contacts to promote cell-adhesion and inhibit migration in the absence of ligand. N-cadherin stimulates FGFR1dependent activation of SRC and p120 catenin, which, in turn, secures $\mathrm{N}$-cadherin-actin interactions [301]. FGF1 and FGF2 have been show to regulate E-cadherin-Catenin signaling in pancreatic adenocarcinoma [302]. E-cadherin directly regulates FGF-mediated FGFR1 endocytosis into the early endosome, and subsequent nuclear translocation, which is disrupted by stabilizing E-cadherin at the cell surface [303].

Nectin-1, a member of the Nectin family of Ig-like CAMs, is able to bind and signal through FGFR [304]. Although this signaling complex has not been investigated in cancer, Nectin-4 enhancement of HER2 signaling has been investigated in relation to tyrosine kinase inhibitor-resistance in breast cancer [305].

Other adhesion molecules that directly interact with FGFR to mediate signaling in a cancer setting include the focal adhesion nonreceptor protein tyrosine kinase 2 (PYK2). Direct interaction of the PYK2 kinase domain with the FGFR3 juxtamembrane domain 
links FGFR3 activation to STAT5 signaling in a MM cell line. This interaction reduces MM cell dependence on SFK activation of PYK2 and STAT5 signaling [276].

\subsection{Other Transmembrane Proteins}

Similar expression to FGF (SEF, also IL-17RD) was identified in Zebrafish as a transmembrane protein that directly interacts with FGFR1 and FGFR2 to negatively regulate signaling [306]. SEF, which in the absence of stimulation resides in vesicles in the cytoplasm, colocalizes with FGFR at the plasma membrane to inhibit FGF2-mediated RAS-MAPK signaling [307-309]. Interestingly, SEF activity on EGFR is strikingly different. Downstream of EGF, SEF can regulate EGFR trafficking to increase EGFR sorting into the early/recycling endosome, which in the absence of SEF is predominantly sorted into late endosomes [310]. ERK1/2 translocation to the nucleus is also prevented by SEF, which instead promotes cytoplasmic ERK1/2 signaling [311]. Despite these opposing roles in regulating RTK activity, SEF is associated with having tumor suppressor activity. SEF can negatively regulate EMT in breast cancer cells [312] and in prostate cancer [313], in which loss of SEF activity has previously been associated with invasiveness and increased bone metastasis [314]. Similarly, in endometrial adenocarcinoma cells, SEF expression inhibited MAPK activation and proliferation in response to FGF2 stimulation [315].

Polypeptide $N$-acetyl galactosaminyltransferase 14 (GALNT14) belongs to the GALNT family of proteins that initiate O-glycosylation of proteins. GALNT14 is a transmembrane protein with large intracellular domain that has been associated with multiple cancer processes, including the promotion of breast cancer metastasis to the lung. In breast cancer cell lines, GALNT14 O-glycosylation of FGFR1 primes breast cancer cells to respond to FGFR activation [264].

Bone morphogenic protein (BMP) has a role in promoting breast cancer progression, likely in promotion of breast cancer metastasis to the bone [316]. Although not directly linked to cancer, BMP4 has been shown to prime FGFR to response to FGF2, FGF7 and FGF10 activation to increase proliferation in mammary epithelial cells [317].

Neuropilins (NRPs) are nonenzymatic transmembrane glycoproteins with emerging roles in cancer progression, with particular focus on NRP-VEGFR signaling in angiogenesis [318]. NRP1 forms a complex with FGFR1 in the cytoplasm, which increases during EMT in HER2 ${ }^{+}$drug-resistant breast cancer cells. This suggests a role for NRP1-mediated FGFR signaling in breast cancer progression and EMT [272].

\subsection{Other Receptor Tyrosine Kinases}

Although FGFR signaling has been mainly considered to occur as a result of ligandmediated formation of homodimers, it has been demonstrated that FGFR1-3 can form heterodimers [319] also between alternative splice isoforms [33]. These alternatively spliced isoform heterodimers are proposed to have differential ability to activate signaling pathways. FGFR1-3 heterodimers are evidenced by transphosphorylation between FGFR1 and FGFR2, suggestive of the formation of heterodimers [320]. Del Picollo et al. (2017) showed that two mutations, A391E and G380R, in FGFR3 stabilized the formation of heterodimers between mutated FGFR3 and wild type FGFR1-3. Although not investigated in cancer, heterodimerization within other RTK families, particularly EGFR, is known to mediate critical signaling in tumorigenesis [321].

The juxtamembrane domain of FGFR1-4 is able to directly interact with the tyrosine kinase domain of Ephrin type A receptor 4 (EPHA4) [322], which forms a complex with FRS2 $\alpha$ [323]. Further to this, a recent study investigating the strength of RTK heterodimers demonstrated that FGFR1-3 can form a complex with EPHA2, as well as with VEGFR2 [324]. An FGFR1-EPHA4 complex potentiates FGFR-mediated signaling, which when complexed with FGFR2 increases proliferation and migration in a glioma cell line [325]. EPHA4dependent phosphorylation of a guanine nucleotide exchange factor Rho family GTPase, Ephexin-1, is inhibited by FGFR inhibition, suggesting a coregulatory relationship where FGFR differentially regulates EPHA4 signaling [262]. Similarly, GRB4 (also known as 
TCK2) interacts with EPHB1 in the presence of activated FGFR1 [326]. EPHA2 expression and activation can be regulated by FGF2 in a colonic adenocarcinoma cell line [327].

FGFR1 has been shown to directly interact with platelet-derived growth factor $\alpha$ (PDGFRA) in response to activation of both receptors, possibly as a mechanism of negatively regulating FGFR signaling [328]. An in-depth investigation into FGFR interactions with PDGFR showed that a direct interaction between FGFR1 and PDGFR- $\beta$ (PDGFRB) requires the intracellular and extracellular domain of the receptor, as well as FRS2. In response to the PDGFR ligand PDGF-BB, FGFR1 was tyrosine phosphorylated in vascular smooth muscle cells. Even though this complex required FRS2, the proliferation and plasticity response did not depend on activation of ERK1/2 [329]. Although the possible role of FGFR-PDGFR interactions has not been investigated in cancer, it is well established that crosstalk exists between their respective ligands during angiogenesis [330,331].

Fusion proteins containing the RTK rearranged during transfection (RET) have been reported in multiple cancer types. The RET domain of RET-kinesin family member 5B (RETKIF5B) fusion protein interacts with FGFR and EGFR in endocytic RAB vesicles to increase FGFR and EGFR activation. This RAB-positive endocytic vesicle kinase "signaling hub" contributes to invadopodia formation. Inhibition of FGFR or EGFR, in combination with the RET inhibitor sorafenib, significantly improved response to treatment in human cancer cell lines harboring the RET-HIF5B fusion protein [273]. This highlights the role of differential FGFR trafficking in mediating FGFR interactome and subsequent downstream signaling.

As for other RTK families, interactions and subsequent signaling are yet to be fully understood in cancer. For example, an interaction between FGFR1 and EGFR can marginally increase epidermal growth factor (EGF)-mediated AKT and STAT3 signaling outputs in lung cancer cells [261]. Along this line, we have recently showed that FGFR2-IgIIIlb and EGFR engage in reciprocal regulation of each other's signaling and trafficking in breast cancer cells [275], confirming that FGFR trafficking regulation may become a target for therapeutic intervention.

\subsection{Serine Threonine Kinases}

Complex crosstalk exists between TGF $\beta$ and FGFR signaling. TGF $\beta$ binds TGF $\beta$ receptor (TGFBR). TGFBR1 and TGFRB2 are serine/threonine/tyrosine kinases, whereas TGFBR3 has no intracellular kinase activity. As with all TGFBR signaling, the signaling and cellular outputs downstream of FGFR-TGFBR are context-dependent, heavily dependent on cell type, the environment and other signaling pathways [332]. In hepatoma cells, tumorigenic TGF $\beta$ activity is switched to a tumor-suppressive activity when FGFR is inhibited, suggesting crosstalk between FGFR and TGFBR activity promotes TGF $\beta$-mediated malignancy [333]. In tumor endothelial cells, FGF2 switches the TGF $\beta$ endothelial-tomyothelial program to differentiate into active fibroblastic cells through activation of E26 transcription factor ELK1, a downstream target of ERK1/2 activation [334]. Alternatively, a negative relationship has been characterized in CAFs, where FGF inhibits TGF $\beta$-promotion of invasion and metastasis [335]. In cancer, a direct interaction between FGFR1 and TGFBR3 has been identified in neuroblastoma cells for which TGFBR3 expression decreases with tumor progression. A complex of FGF2-FGFR1-TGFBR3 activates ERK1/2 signaling and increases expression of inhibitor of DNA binding 1 transcription factor (ID1) expression, ultimately promoting differentiation of neuroblastoma cells. The signaling axis is able to suppress tumor growth and metastasis in vivo [274]. The cell-type-dependent FGFR regulation of TGF $\beta$ signaling reinforces the relevance of context dependent FGFR signaling in cancer.

TGF $\alpha$-activated kinase 1 (TAK1, also MAP3K7) forms a complex with TAK1-binding protein 1 (TAB1) and TAB2/3, and orchestrates a wide range of signal transduction pathways including MAPK, nuclear factor $\mathrm{KB}(\mathrm{NFKB})$, noncanonical WNT and AKT signaling, through which it contributes to oncogenic signaling [336]. A direct interaction between FGFR3 and TAK1 increases with mutations in FGFR3 known to occur in MM and bladder cancer. In the presence of these FGFR3 mutations, the interaction likely increases cell 
adhesion and NFKB-dependent transcription, as demonstrated by the dependency on the expression of TAK1 [277].

\section{Conclusions and Perspectives}

The diversified role of FGFR partners in regulating FGFR activation and signaling supports the relevance of FGF/FGFR pairs in tumorigenesis. By directly interacting with several co-expressed signaling partners, FGFRs can facilitate, amplify or inhibit key tumor progression processes. Not only does this result in signaling events directly dependent on FGF/FGFR, but also indicates a role for FGFR signaling in tumors where FGFR genetic alterations are not easily detectable. Rather, FGFR expression can influence activity of alternative oncogenic signaling axes. A large number of studies highlight the contextdependent nature of FGFR signaling, re-emphasizing the importance of the global FGFR proteome and interactome in several cancer types. Comprehensively defining the landscape of FGFR signaling partners in multiple cancers could be exploited to select more efficient drug combinations. As demonstrated by Das and Cagan (2017), RTK signaling is differentially regulated by localization of the receptors, in part due to the colocalized interactome of each receptor [273]. As differential trafficking of FGFR drives intracellular signaling, we speculate that FGFR colocalization with noncanonical signaling partners, including EGFR, may contribute to novel FGFR oncogenic functions. For instance, FGF10/FGFR2IgIIIb-dependent phosphorylation of EGFR on threonine (T) 693 in breast cancer cells and organoids regulates FGFR2-IgIIIb trafficking and signaling outputs, including cell proliferation [275]. This might have implications in TNBC, where both FGFRs and EGFR are highly expressed [337], and where this phosphorylated site may become a prognostic or predictive marker if a correlation between T693 phosphorylation, clinical parameters, and the response to combined EGFR/FGFR therapies are determined. This idea is supported by the detection of T693 phosphorylation in $50 \%$ of the TNBC patient-derived samples analyzed in two independent phosphoproteomics datasets [338,339].

It remains to be determined whether other FGFR signaling cofactors implicated in development may regulate FGFR signaling in cancer. For example, G protein-coupled receptor (GPCR) expression and activity have been implicated in both tumorigenesis and tumor suppression [340]. In addition to this, GPCR-RTK complexes have a role in tumorigenesis [341]. Given that GPCR-mediated activation of FGFR signaling is involved in development [14], it is plausible that the GPCR-FGFR signaling axis plays a role in tumorigenesis yet to be characterized.

In conclusion, canonical FGF-FGFR signaling contributes to tumorigenesis in a contextdependent manner. Noncanonical FGFR signaling partners are critical in regulating oncogenic FGF-FGFR signaling partners and support a role for FGFR signaling in the absence of FGFR genetic aberration.

Author Contributions: Conceptualization, C.F.; writing—original draft preparation, H.R.F.; writingreview and editing, C.F., M.P.S., H.R.F.; supervision, M.P.S. and C.F.; project administration, C.F.; funding acquisition, C.F. All authors have read and agreed to the published version of the manuscript.

Funding: Research in CF lab is supported by Wellcome Trust (WT Sir Henry Dale fellowship 107636/Z/15/Z), the Biotechnology and Biological Sciences Research Council (BB/R015864/1), and the Medical Research Council (MR/T016043/1). HRF is supported by BBSRC Doctoral Training Programme (BB/M011208/1).

Acknowledgments: We thank all members of $\mathrm{CF}^{\prime}$ s team for useful suggestions and discussion.

Conflicts of Interest: The authors declare no conflict of interest. 


\section{Abbreviations}

aFGF Acidic FGF

AHCYL1 S-adenosylhomocysteine hydrolase-like protein 1

ANOS1 Anosmin-1 or KAL1

bFGF Basic FGF

BICC1 BicC family RNA binding protein 1

BMP Bone morphogenic protein

CAFs Cancer associated fibroblasts

CAMs Cell adhesion molecules

CBL E3-ubiquitin ligase CBL

CCDC6 Coiled-coil domain containing protein 6

CRC Colorectal cancer

CRK Chicken tumor virus no. 10 regulator of kinase

CRKL Closely related CRK-like

DAG Diacylglycerol

DUSP6 Dual specificity phosphatase 6

ECM Extracellular matrix

EGF Epidermal growth factor

EMT Epithelial-mesenchymal transition

EPHA1/2/4 Ephrin type A receptor 1/2/4

EPHB1 Ephrin type B receptor 1

ER Endoplasmic reticulum

ER Estrogen receptor

ERK1/2 Extracellular signal-regulated protein kinase 1/2

ESRP1/2 Epithelial splicing regulatory protein 1/2

FAK Focal adhesion kinase

FGF Fibroblast Growth Factor

FGFR Fibroblast Growth Factor Receptor

FGFRL1 FGFR like 1

FHFs Fibroblast homologous factors

FRS2 FGFR substrate 2

GALNT14 Polypeptide N-acetyl galactosaminyltransferase

GIST

Gastrointestinal stromal tumors

GPCR G protein-coupled receptors

GRB2/14 Growth factor receptor bound 2/14

HCC Hepatocellular carcinoma

HER2 Human epidermal growth factor receptor 2

HSPGs Heparan Sulfate Proteoglycans

ID1 Inhibitor of DNA binding 1 transcription factor

iFGF Intracellular FGF

IgI-IgIII Immunoglobulin-like looped domains I-III

IgSF Immunoglobulin superfamily

$\mathrm{IP}_{3} \quad$ Inositol trisphosphate

KGF Keratinocyte growth factor

KIAA1217 Sickle tail protein homolog

KIF5B Kinesin family member 5B

LGALS1/3 Galectin-1/3

MAPK Mitogen activated protein kinase

miRNA Micro RNA

MM Multiple myeloma

MMP9 Matrix metallopeptidase 9

mTOR Mammalian target of rapamycin

NCAM Neural cell adhesion molecule

NFKB Nuclear factor kappa-light-chain-enhancer of activated B cells

NRPs Neuropilins

NSCLC Nonsmall cell lung cancer

PDAC Pancreatic ductal adenocarcinoma 


$\begin{array}{ll}\text { PDGFRA } & \text { Platelet derived growth factor } \alpha \\ \text { PDPK1 } & \text { 3-phosphoinositide-dependent protein kinase 1 } \\ \text { PI3K } & \text { Phosphatidylinositide 3-kinase } \\ \text { PI3KR1/2 } & \text { PI3K subunit alpha/beta or p85 PI3K subunit } \\ \text { PIP }_{2} & \text { Phosphatidylinositol 4,5-bisphosphate } \\ \text { PIP }_{3} & \text { Phosphatidylinositol 3,4,5-trisphosphate } \\ \text { PKC } & \text { Protein kinase C } \\ \text { PLC } \gamma & \text { Phospholipase C gamma } \\ \text { PP2A } & \text { Protein phosphatase 2A } \\ \text { PTPRG } & \text { Protein tyrosine phosphatase 6 } \\ \text { ptdFGFR4 } & \text { Pituitary-derived FGFR4 } \\ \text { PTPN11 } & \text { Protein tyrosine phosphatase nonreceptor type 11 } \\ \text { PYK2 } & \text { Nonreceptor protein tyrosine kinase 2 } \\ \text { RET } & \text { Rearranged during transfection } \\ \text { RSK2 } & \text { Ribosomal S6 kinase 2 } \\ \text { RTK } & \text { Receptor Tyrosine Kinase } \\ \text { SEF } & \text { Similar expression to FGF } \\ \text { SFK } & \text { SRC-family kinases } \\ \text { SH2 } & \text { SRC homology 2 } \\ \text { SH3BP4 } & \text { SH3-binding protein 4 } \\ \text { SHC } & \text { SRC-homology-2 containing transforming protein } \\ \text { SHIP2 } & \text { Phosphatidylinositol 3,4,5-trisphosphate 5-phosphatase 2 } \\ \text { SNP } & \text { Single nucleotide polymorphism } \\ \text { SPRY1/2/4 } & \text { Sprouty 1/2/4 } \\ \text { STAT1/3/5 } & \text { Signal transducer and activator of transcription 1/3/5 } \\ \text { TAB1 } & \text { TAK1-binding protein } \\ \text { TACC1/3 } & \text { Transforming acidic coiled coil 1/3 } \\ \text { TAK1 } & \text { TGF } \alpha \text {-activated kinase 1 } \\ \text { TGFBR1/3 } & \text { TGF } \beta \text { receptor 1/3 } \\ \text { TGF } \beta & \text { Transforming growth factor beta } \\ \text { TNBC } & \text { Triple negative breast cancer } \\ \text { VEGFR } & \text { Vascular endothelial growth factor receptor } \\ \text { Y } & \text { Tyrosine } \\ & \end{array}$

\section{References}

1. Wintheiser, G.A.; Silberstein, P. Physiology, tyrosine kinase receptors. Statpearls 2020, internet.

2. Bennasroune, A.; Gardin, A.; Aunis, D.; Cremel, G.; Hubert, P. Tyrosine kinase receptors as attractive targets of cancer therapy. Crit. Rev. Oncol. Hematol. 2004, 50, 23-38. [CrossRef]

3. Ornitz, D.M.; Itoh, N. The Fibroblast Growth Factor signaling pathway. Wiley Interdiscip. Rev. Dev. Biol. 2015, 4, 215-266. [CrossRef] [PubMed]

4. Sobhani, N.; Fan, C.M.; Flores-Villanueva, P.O.; Generali, D.; Li, Y. The Fibroblast Growth Factor Receptors in Breast Cancer: From Oncogenesis to Better Treatments. Int. J. Mol. Sci. 2020, 21, 2011. [CrossRef]

5. Gartside, M.G.; Chen, H.B.; Ibrahimi, O.A.; Byron, S.A.; Curtis, A.V.; Wellens, C.L.; Bengston, A.; Yudt, L.M.; Eliseenkova, A.V.; Ma, J.H.; et al. Loss-of-Function Fibroblast Growth Factor Receptor-2 Mutations in Melanoma. Mol. Cancer Res. 2009, 7, 41-54. [CrossRef]

6. Ricol, D.; Cappellen, D.; El Marjou, A.; Gil-Diez-de-Medina, S.; Girault, J.M.; Yoshida, T.; Ferry, G.; Tucker, G.; Poupon, M.F.; Chopin, D.; et al. Tumour suppressive properties of fibroblast growth factor receptor 2-IIIb in human bladder cancer. Oncogene 1999, 18, 7234-7243. [CrossRef] [PubMed]

7. Amann, T.; Bataille, F.; Spruss, T.; Dettmer, K.; Wild, P.; Liedtke, C.; Muhlbauer, M.; Kiefer, P.; Oefner, P.J.; Trautwein, C.; et al. Reduced Expression of Fibroblast Growth Factor Receptor 2IIIb in Hepatocellular Carcinoma Induces a More Aggressive Growth. Am. J. Pathol. 2010, 176, 1433-1442. [CrossRef] [PubMed]

8. Kim, H.S.; Kim, J.H.; Jang, H.J.; Han, B.; Zang, D.Y. Pathological and Prognostic Impacts of FGFR2 Overexpression in Gastric Cancer: A Meta-Analysis. J. Cancer 2019, 10, 20-27. [CrossRef] [PubMed]

9. Matsumoto, K.; Arao, T.; Hamaguchi, T.; Shimada, Y.; Kato, K.; Oda, I.; Taniguchi, H.; Koizumi, F.; Yanagihara, K.; Sasaki, H.; et al. FGFR2 gene amplification and clinicopathological features in gastric cancer. Br. J. Cancer 2012, 106, 727-732. [CrossRef] [PubMed]

10. Turner, N.; Lambros, M.B.; Horlings, H.M.; Pearson, A.; Sharpe, R.; Natrajan, R.; Geyer, F.C.; van Kouwenhove, M.; Kreike, B.; Mackay, A.; et al. Integrative molecular profiling of triple negative breast cancers identifies amplicon drivers and potential therapeutic targets. Oncogene 2010, 29, 2013-2023. [CrossRef] 
11. Campbell, J.; Ryan, C.J.; Brough, R.; Bajrami, I.; Pemberton, H.N.; Chong, I.Y.; Costa-Cabral, S.; Frankum, J.; Gulati, A.; Holme, H.; et al. Large-Scale Profiling of Kinase Dependencies in Cancer Cell Lines. Cell Rep. 2016, 14, 2490-2501. [CrossRef]

12. Vecchione, A.; Cooper, H.J.; Trim, K.J.; Akbarzadeh, S.; Heath, J.K.; Wheldon, L.M. Protein partners in the life history of activated fibroblast growth factor receptors. Proteomics 2007, 7, 4565-4578. [CrossRef] [PubMed]

13. Balek, L.; Nemec, P.; Konik, P.; Bosakova, M.K.; Varecha, M.; Gudernova, I.; Medalova, J.; Krakow, D.; Krejci, P. Proteomic analyses of signalling complexes associated with receptor tyrosine kinase identify novel members of fibroblast growth factor receptor 3 interactome. Cell. Signal. 2018, 42, 144-154. [CrossRef] [PubMed]

14. Latko, M.; Czyrek, A.; Porebska, N.; Kucinska, M.; Otlewski, J.; Zakrzewska, M.; Opalinski, L. Cross-Talk between Fibroblast Growth Factor Receptors and Other Cell Surface Proteins. Cells 2019, 8, 455. [CrossRef]

15. Lee, P.L.; Johnson, D.E.; Cousens, L.S.; Fried, V.A.; Williams, L.T. Purification and complementary-dna cloning of a receptor for basic fibroblast growth-factor. Science 1989, 245, 57-60. [CrossRef] [PubMed]

16. Ruta, M.; Howk, R.; Ricca, G.; Drohan, W.; Zabelshansky, M.; Laureys, G.; Barton, D.E.; Francke, U.; Schlessinger, J.; Givol, D. A novel protein tyrosine kinase gene whose expression is modulated during endothelial-cell differentiation. Oncogene 1988, 3, 9-15.

17. Ruta, M.; Burgess, W.; Givol, D.; Epstein, J.; Neiger, N.; Kaplow, J.; Crumley, G.; Dionne, C.; Jaye, M.; Schlessinger, J. Receptor for Acidic Fibroblast Growth-Factor is Related to the Tyrosine Kinase Encoded by the Fms-Like Gene (Flg). Proc. Natl. Acad. Sci. USA 1989, 86, 8722-8726. [CrossRef] [PubMed]

18. Kornbluth, S.; Paulson, K.E.; Hanafusa, H. Novel tyrosine kinase identified by phosphotyrosine antibody screening of cDNA libraries. Mol. Cell. Biol. 1988, 8, 5541-5544. [CrossRef]

19. Keegan, K.; Johnson, D.E.; Williams, L.T.; Hayman, M.J. Isolation of an additional member of the fibroblast growth-factor receptor family, FGFR-3. Proc. Natl. Acad. Sci. USA 1991, 88, 1095-1099. [CrossRef]

20. Partanen, J.; Makela, T.P.; Eerola, E.; Korhonen, J.; Hirvonen, H.; Claessonwelsh, L.; Alitalo, K. FGFR-4, a novel acidic fibroblast growth-factor receptor with a distinct expression pattern. EMBO J. 1991, 10, 1347-1354. [CrossRef] [PubMed]

21. Sleeman, M.; Fraser, J.; McDonald, M.; Yuan, S.N.; White, D.; Grandison, P.; Kumble, K.; Watson, J.D.; Murison, J.G. Identification of a new fibroblast growth factor receptor, FGFR5. Gene 2001, 271, 171-182. [CrossRef]

22. Wiedemann, M.; Trueb, B. Characterization of a novel protein (FGFRL1) from human cartilage related to FGF receptors. Genomics 2000, 69, 275-279. [CrossRef] [PubMed]

23. Regeenes, R.; Silva, P.N.; Chang, H.H.; Arany, E.J.; Shukalyuk, A.I.; Audet, J.; Kilkenny, D.M.; Rocheleau, J.V. Fibroblast growth factor receptor 5 (FGFR5) is a co-receptor for FGFR1 that is up-regulated in beta-cells by cytokine-induced inflammation. J. Biol. Chem. 2018, 293, 17218-17228. [CrossRef] [PubMed]

24. Silva, P.N.; Altamentova, S.M.; Kilkenny, D.M.; Rocheleau, J.V. Fibroblast Growth Factor Receptor Like-1 (FGFRL1) Interacts with SHP-1 Phosphatase at Insulin Secretory Granules and Induces Beta-cell ERK1/2 Protein Activation. J. Biol. Chem. 2013, 288, 17859-17870. [CrossRef] [PubMed]

25. Johnson, D.E.; Lu, J.; Chen, H.; Werner, S.; Williams, L.T. The human fibroblast growth-factor receptor genes-a common structural arrangement underlies the mechanisms for generating receptor forms that differ in their 3rd immunoglobulin domain. Mol. Cell. Biol. 1991, 11, 4627-4634. [CrossRef]

26. Werner, S.; Duan, D.S.R.; Devries, C.; Peters, K.G.; Johnson, D.E.; Williams, L.T. Differential splicing in the extracellular region of fibroblast growth-factor receptor-1 generates receptor variants with different ligand-binding specificities. Mol. Cell. Biol. 1992, 12, 82-88. [CrossRef]

27. Miki, T.; Bottaro, D.P.; Fleming, T.P.; Smith, C.L.; Burgess, W.H.; Chan, A.M.L.; Aaronson, S.A. Determination of ligand-binding specificity by alternative splicing-2 distinct growth-factor receptors encoded by a single gene. Proc. Natl. Acad. Sci. USA 1992, 89, 246-250. [CrossRef]

28. Yayon, A.; Zimmer, Y.; Shen, G.H.; Avivi, A.; Yarden, Y.; Givol, D. A Confined variable region confers ligand specificity on fibroblast growth-factor receptors-implications for the origin of the immunoglobulin fold. EMBO J. 1992, 11, 1885-1890. [CrossRef]

29. Orrurtreger, A.; Bedford, M.T.; Burakova, T.; Arman, E.; Zimmer, Y.; Yayon, A.; Givol, D.; Lonai, P. Developmental localization of the splicing alternatives of fibroblast growth-factor receptor-2 (fgfr2). Dev. Biol. 1993, 158, 475-486. [CrossRef]

30. Warzecha, C.C.; Sato, T.K.; Nabet, B.; Hogenesch, J.B.; Carstens, R.P. ESRP1 and ESRP2 Are Epithelial Cell-Type-Specific Regulators of FGFR2 Splicing. Mol. Cell 2009, 33, 591-601. [CrossRef]

31. Johnson, D.E.; Lee, P.L.; Lu, J.; Williams, L.T. Diverse forms of a receptor for acidic and basic fibroblast growth-factors. Mol. Cell. Biol. 1990, 10, 4728-4736. [CrossRef]

32. Hou, J.Z.; Kan, M.; McKeehan, K.; McBride, G.; Adams, P.; McKeehan, W.L. Fibroblast growth-factor receptors from liver vary in 3 structural domains. Science 1991, 251, 665-668. [CrossRef]

33. Shi, E.; Kan, M.; Xu, J.M.; Wang, F.; Hou, J.Z.; McKeehan, W.L. Control of fibroblast growth-factor receptor kinase signaltransduction by heterodimerization of combinatorial splice variants. Mol. Cell. Biol. 1993, 13, 3907-3918. [CrossRef] [PubMed]

34. Kalinina, J.; Dutta, K.; Ilghari, D.; Beenken, A.; Goetz, R.; Eliseenkova, A.V.; Cowburn, D.; Mohammadi, M. The Alternatively Spliced Acid Box Region Plays a Key Role in FGF Receptor Autoinhibition. Structure 2012, 20, 77-88. [CrossRef] [PubMed]

35. Hattori, Y.; Odagiri, H.; Nakatani, H.; Miyagawa, K.; Naito, K.; Sakamoto, H.; Katoh, O.; Yoshida, T.; Sugimura, T.; Terada, M. K-SAM, an amplified gene in stomach-cancer, is a member of the heparin-binding growth-factor receptor genes. Proc. Natl. Acad. Sci. USA 1990, 87, 5983-5987. [CrossRef] [PubMed] 
36. Shimizu, A.; Tada, K.; Shukunami, C.; Hiraki, Y.; Kurokawa, T.; Magane, N.; Kurokawa-Seo, M. A novel alternatively spliced fibroblast growth factor receptor 3 isoform lacking the acid box domain is expressed during chondrogenic differentiation of ATDC5 cells. J. Biol. Chem. 2001, 276, 11031-11040. [CrossRef]

37. Miki, T.; Fleming, T.P.; Bottaro, D.P.; Rubin, J.S.; Ron, D.; Aaronson, S.A. Expression cDNA cloning of the KGF receptor by creation of a transforming autocrine loop. Science 1991, 251, 72-75. [CrossRef]

38. Bae, J.H.; Boggon, T.J.; Tome, F.; Mandiyan, V.; Lax, I.; Schlessinger, J. Asymmetric receptor contact is required for tyrosine autophosphorylation of fibroblast growth factor receptor in living cells. Proc. Natl. Acad. Sci. USA 2010, 107, 2866-2871. [CrossRef]

39. Peng, W.C.; Lin, X.; Torres, J. The strong dimerization of the transmembrane domain of the fibroblast growth factor receptor (FGFR) is modulated by C-terminal juxtamembrane residues. Protein Sci. 2009, 18, 450-459. [CrossRef]

40. Mohammadi, M.; Dikic, I.; Sorokin, A.; Burgess, W.H.; Jaye, M.; Schlessinger, J. Identification of six novel autophosphorylation sites on fibroblast growth factor receptor 1 and elucidation of their importance in receptor activation and signal transduction. Mol. Cell. Biol. 1996, 16, 977-989. [CrossRef] [PubMed]

41. Mohammadi, M.; Honegger, A.M.; Rotin, D.; Fischer, R.; Bellot, F.; Li, W.; Dionne, C.A.; Jaye, M.; Rubinstein, M.; Schlessinger, J. A tyrosine-phosphorylated carboxy-terminal peptide of the fibroblast growth-factor receptor (FLG) is a binding-site for the sh2 domain of phospholipase C-gamma-1. Mol. Cell. Biol. 1991, 11, 5068-5078. [CrossRef]

42. Francavilla, C.; Rigbolt, K.T.G.; Emdal, K.B.; Carraro, G.; Vernet, E.; Bekker-Jensen, D.B.; Streicher, W.; Wikstrom, M.; Sundstrom, M.; Bellusci, S.; et al. Functional Proteomics Defines the Molecular Switch Underlying FGF Receptor Trafficking and Cellular Outputs. Mol. Cell 2013, 51, 707-722. [CrossRef] [PubMed]

43. Salazar, L.; Kashiwada, T.; Krejci, P.; Muchowski, P.; Donoghue, D.; Wilcox, W.R.; Thompson, L.M. A novel interaction between fibroblast growth factor receptor 3 and the p85 subunit of phosphoinositide 3-kinase: Activation-dependent regulation of ERK by p85 in multiple myeloma cells. Hum. Mol. Genet. 2009, 18, 1951-1961. [CrossRef]

44. Kouhara, H.; Hadari, Y.R.; SpivakKroizman, T.; Schilling, J.; BarSagi, D.; Lax, I.; Schlessinger, J. A lipid-anchored Grb2-binding protein that links FGF-receptor activation to the Ras/MAPK signaling pathway. Cell 1997, 89, 693-702. [CrossRef]

45. Ong, S.H.; Guy, G.R.; Hadari, Y.R.; Laks, S.; Gotoh, N.; Schlessinger, J.; Lax, I. FRS2 proteins recruit intracellular signaling pathways by binding to diverse targets on fibroblast growth factor and nerve growth factor receptors. Mol. Cell. Biol. 2000, 20, 979-989. [CrossRef]

46. Hadari, Y.R.; Kouhara, H.; Lax, I.; Schlessinger, J. Binding of Shp2 tyrosine phosphatase to FRS2 is essential for fibroblast growth factor-induced PC12 cell differentiation. Mol. Cell. Biol. 1998, 18, 3966-3973. [CrossRef]

47. Larsson, H.; Klint, P.; Landgren, E.; Claesson-Welsh, L. Fibroblast growth factor receptor-1-mediated endothelial cell proliferation is dependent on the Src homology (SH) 2/SH3 domain-containing adaptor protein Crk. J. Biol. Chem. 1999, 274, 25726-25734. [CrossRef] [PubMed]

48. Seo, J.H.; Suenaga, A.; Hatakeyama, M.; Taiji, M.; Imamoto, A. Structural and Functional Basis of a Role for CRKL in a Fibroblast Growth Factor 8-Induced Feed-Forward Loop. Mol. Cell. Biol. 2009, 29, 3076-3087. [CrossRef] [PubMed]

49. Collins, T.N.; Mao, Y.Y.; Li, H.G.; Bouaziz, M.; Hong, A.; Feng, G.S.; Wang, F.; Quilliam, L.A.; Chen, L.; Park, T.; et al. Crk proteins transduce FGF signaling to promote lens fiber cell elongation. eLife 2018, 7. [CrossRef] [PubMed]

50. Moon, A.M.; Guris, D.L.; Seo, J.H.; Li, L.M.; Hammond, J.; Talbot, A.; Imamoto, A. Crkl deficiency disrupts Fgf8 signaling in a mouse model of 22q11 deletion syndromes. Dev. Cell 2006, 10, 71-80. [CrossRef] [PubMed]

51. Fafilek, B.; Balek, L.; Bosakova, M.K.; Varecha, M.; Nita, A.; Gregor, T.; Gudernova, I.; Krenova, J.; Ghosh, S.; Piskacek, M.; et al. The inositol phosphatase SHIP2 enables sustained ERK activation downstream of FGF receptors by recruiting Src kinases. Sci. Signal. 2018, 11. [CrossRef] [PubMed]

52. Krejci, P.; Aklian, A.; Kaucka, M.; Sevcikova, E.; Prochazkova, J.; Masek, J.K.; Mikolka, P.; Pospisilova, T.; Spoustova, T.; Weis, M.; et al. Receptor Tyrosine Kinases Activate Canonical WNT/beta-Catenin Signaling via MAP Kinase/LRP6 Pathway and Direct beta-Catenin Phosphorylation. PLoS ONE 2012, 7. [CrossRef] [PubMed]

53. Kang, S.; Elf, S.; Dong, S.; Hitosugi, T.; Guo, A.; Ruan, H.; Lonial, S.; Khoury, H.; Williams, I.; Karsenty, G.; et al. FGFR3 Associates with and Tyrosine-Phosphorylates p90RSK2, Leading to RSK2 Activation That Mediates Hematopoietic Transformation. Blood 2008, 112, 1276. [CrossRef]

54. Kang, S.; Elf, S.; Dong, S.; Hitosugi, T.; Lythgoe, K.; Guo, A.; Ruan, H.; Lonial, S.; Khoury, H.J.; Williams, I.R.; et al. Fibroblast Growth Factor Receptor 3 Associates with and Tyrosine Phosphorylates p90 RSK2, Leading to RSK2 Activation That Mediates Hematopoietic Transformation. Mol. Cell. Biol. 2009, 29, 2105-2117. [CrossRef]

55. Ong, S.H.; Hadari, Y.R.; Gotoh, N.; Guy, G.R.; Schlessinger, J.; Lax, I. Stimulation of phosphatidylinositol 3-kinase by fibroblast growth factor receptors is mediated by coordinated recruitment of multiple docking proteins. Proc. Natl. Acad. Sci. USA 2001, 98, 6074-6079. [CrossRef]

56. Weylie, B.; Zhu, J.; Singh, U.; Ambrus, S.; Forough, R. Phosphatidylinositide 3-kinase is important in late-stage fibroblast growth factor-1-mediated angiogenesis in vivo. J. Vasc. Res. 2006, 43, 61-69. [CrossRef] [PubMed]

57. Forough, R.; Weylie, B.; Patel, C.; Ambrus, S.; Singh, L.S.; Zhu, J. Role of AKT/PKB signaling in fibroblast growth factor-1 (FGF-1)-induced angiogenesis in the chicken chorioallantoic membrane (CAM). J. Cell. Biochem. 2005, 94, 109-116. [CrossRef]

58. Easton, D.F.; Pooley, K.A.; Dunning, A.M.; Pharoah, P.D.P.; Thompson, D.; Ballinger, D.G.; Struewing, J.P.; Morrison, J.; Field, H.; Luben, R.; et al. Genome-wide association study identifies novel breast cancer susceptibility loci. Nature 2007, $447,1087$. [CrossRef] 
59. Yang, X.H.; Qiao, D.H.; Meyer, K.; Friedl, A. Signal Transducers and Activators of Transcription Mediate Fibroblast Growth Factor-Induced Vascular Endothelial Morphogenesis. Cancer Res. 2009, 69, 1668-1677. [CrossRef]

60. Su, W.C.S.; Kitagawa, M.; Xue, N.R.; Xie, B.; Garofalo, S.; Cho, J.; Deng, C.X.; Horton, W.A.; Fu, X.Y. Activation of Stat1 by mutant fibroblast growth-factor receptor in thanatophoric dysplasia type II dwarfism. Nature 1997, 386, 288-292. [CrossRef]

61. Hart, K.C.; Robertson, S.C.; Kanemitsu, M.Y.; Meyer, A.N.; Tynan, J.A.; Donoghue, D.J. Transformation and Stat activation by derivatives of FGFR1, FGFR3, and FGFR4. Oncogene 2000, 19, 3309-3320. [CrossRef] [PubMed]

62. Dudka, A.A.; Sweet, S.M.M.; Heath, J.K. Signal Transducers and Activators of Transcription-3 Binding to the Fibroblast Growth Factor Receptor Is Activated by Receptor Amplification. Cancer Res. 2010, 70, 3391-3401. [CrossRef] [PubMed]

63. Lonic, A.; Barry, E.F.; Quach, C.; Kobe, B.; Saunders, N.; Guthridge, M.A. Fibroblast growth factor receptor 2 phosphorylation on serine 779 couples to 14-3-3 and regulates cell survival and proliferation. Mol. Cell. Biol. 2008, 28, 3372-3385. [CrossRef]

64. Lonic, A.; Powell, J.A.; Kong, Y.; Thomas, D.; Holien, J.K.; Truong, N.; Parker, M.W.; Guthridge, M.A. Phosphorylation of Serine 779 in Fibroblast Growth Factor Receptor 1 and 2 by Protein Kinase C epsilon Regulates Ras/Mitogen-activated Protein Kinase Signaling and Neuronal Differentiation. J. Biol. Chem. 2013, 288, 14874-14885. [CrossRef]

65. Zakrzewska, M.; Haugsten, E.M.; Nadratowska-Wesolowska, B.; Oppelt, A.; Hausott, B.; Jin, Y.X.; Otlewski, J.; Wesche, J.; Wiedlocha, A. ERK-Mediated Phosphorylation of Fibroblast Growth Factor Receptor 1 on Ser(777) Inhibits Signaling. Sci. Signal. 2013, 6. [CrossRef]

66. Lax, I.; Wong, A.; Lamothe, B.; Lee, A.; Frost, A.; Hawes, J.; Schlessinger, J. The docking protein FRS2 alpha controls a MAP kinase-mediated negative feedback mechanism for signaling by FGF receptors. Mol. Cell 2002, 10, 709-719. [CrossRef]

67. Zakrzewska, M.; Opalinski, L.; Haugsten, E.M.; Otlewski, J.; Wiedlocha, A. Crosstalk between p38 and Erk 1/2 in Downregulation of FGF1-Induced Signaling. Int. J. Mol. Sci. 2019, 20, 1826. [CrossRef]

68. Peng, Y.; Croce, C.M. The role of MicroRNAs in human cancer. Signal Transduct. Target. Ther. 2016, 1. [CrossRef] [PubMed]

69. Yang, Y.; Li, Z.M.; Yuan, H.; Ji, W.X.; Wang, K.X.; Lu, T.T.; Yu, Y.F.; Zeng, Q.Y.; Li, F.; Xia, W.L.; et al. Reciprocal regulatory mechanism between miR-214-3p and FGFR1 in FGFR1-amplified lung cancer. Oncogenesis 2019, 8. [CrossRef] [PubMed]

70. Schelch, K.; Kirschner, M.B.; Williams, M.; Cheng, Y.Y.; van Zandwijk, N.; Grusch, M.; Reid, G. A link between the fibroblast growth factor axis and the miR-16 family reveals potential new treatment combinations in mesothelioma. Mol. Oncol. 2018, 12, 58-73. [CrossRef]

71. Wang, J.; Li, J.W.; Wang, X.C.; Zheng, C.; Ma, W.D. Downregulation of microRNA-214 and overexpression of FGFR-1 contribute to hepatocellular carcinoma metastasis. Biochem. Biophys. Res. Commun. 2013, 439, 47-53. [CrossRef] [PubMed]

72. Gao, G.; Tian, Z.; Zhu, H.Y.; Ouyang, X.Y. miRNA-133b targets FGFR1 and presents multiple tumor suppressor activities in osteosarcoma. Cancer Cell Int. 2018, 18. [CrossRef] [PubMed]

73. Sun, Y.; Cheng, Y.; Zhang, Y.; Han, K. MicroRNA-889-3p targets FGFR2 to inhibit cervical cancer cell viability and invasion. Exp. Ther. Med. 2019, 18, 1440-1448. [CrossRef] [PubMed]

74. Jing, P.Y.; Zhao, N.; Xie, N.L.; Ye, M.X.; Zhang, Y.; Zhang, Z.P.; Li, M.Y.; Lai, X.F.; Zhang, J.; Gu, Z.P. miR-24-3p/FGFR3 Signaling as a Novel Axis Is Involved in Epithelial-Mesenchymal Transition and Regulates Lung Adenocarcinoma Progression. J. Immunol. Res. 2018, 2018. [CrossRef] [PubMed]

75. Lo, T.L.; Yusoff, P.; Fong, C.W.; Guo, K.; McCaw, B.J.; Phillips, W.A.; Yang, H.; Wong, E.S.M.; Leong, H.F.; Zeng, Q.; et al. The Ras/mitogen-activated protein kinase pathway inhibitor and likely tumor suppressor proteins, sprouty 1 and sprouty 2 are deregulated in breast cancer. Cancer Res. 2004, 64, 6127-6136. [CrossRef]

76. Sasaki, A.; Taketomi, T.; Wakioka, T.; Kato, R.; Yoshimura, A. Identification of a dominant negative mutant of sprouty that potentiates fibroblast growth factor-but not epidermal growth factor-induced ERK activation. J. Biol. Chem. 2001, 276, 36804-36808. [CrossRef] [PubMed]

77. Fong, C.W.; Leong, H.F.; Wong, E.S.M.; Lim, J.; Yusoff, P.; Guy, G.R. Tyrosine phosphorylation of Sprouty2 enhances its interaction with c-Cbl and is crucial for its function. J. Biol. Chem. 2003, 278, 33456-33464. [CrossRef]

78. Rubin, C.; Zwang, Y.; Vaisman, N.; Ron, D.; Yarden, Y. Phosphorylation of carboxyl-terminal tyrosines modulates the specificity of sprouty-2 inhibition of different signaling pathways. J. Biol. Chem. 2005, 280, 9735-9744. [CrossRef]

79. Mason, J.M.; Morrison, D.J.; Bassit, B.; Dimri, M.; Band, H.; Licht, J.D.; Gross, I. Tyrosine phosphorylation of sprouty proteins regulates their ability to inhibit growth factor signaling: A dual feedback loop. Mol. Biol. Cell 2004, 15, 2176-2188. [CrossRef]

80. Lao, D.H.; Yusoff, P.; Chandramouli, S.; Philp, R.J.; Fong, C.W.; Jackson, R.A.; Saw, T.Y.; Yu, C.Y.; Guy, G.R. Direct binding of PP2A to Sprouty2 and phosphorylation changes are a prerequisite for ERK inhibition downstream of fibroblast growth factor receptor stimulation. J. Biol. Chem. 2007, 282, 9117-9126. [CrossRef]

81. Li, X.; Brunton, V.G.; Burgar, H.R.; Wheldon, L.M.; Heath, J.K. FRS2-dependent SRC activation is required for fibroblast growth factor receptor-induced phosphorylation of sprouty and suppression of ERK activity. J. Cell Sci. 2004, 117, 6007-6017. [CrossRef]

82. Hanafusa, H.; Torii, S.; Yasunaga, T.; Matsumoto, K.; Nishida, E. Shp2, an SH2-containing protein-tyrosine phosphatase, positively regulates receptor tyrosine kinase signaling by dephosphorylating and inactivating the inhibitor sprouty. J. Biol. Chem. 2004, 279, 22992-22995. [CrossRef] [PubMed]

83. Kostas, M.; Haugsten, E.M.; Zhen, Y.; Sorensen, V.; Szybowska, P.; Fiorito, E.; Lorenz, S.; Jones, N.; de Souza, G.A.; Wiedlocha, A.; et al. Protein Tyrosine Phosphatase Receptor Type G (PTPRG) Controls Fibroblast Growth Factor Receptor (FGFR) 1 Activity and Influences Sensitivity to FGFR Kinase Inhibitors. Mol. Cell. Proteom. 2018, 17, 850-870. [CrossRef] 
84. Nakanishi, Y.; Mizuno, H.; Sase, H.; Fujii, T.; Sakata, K.; Akiyama, N.; Aoki, Y.; Aoki, M.; Ishii, N. ERK Signal Suppression and Sensitivity to CH5183284/Debio 1347, a Selective FGFR Inhibitor. Mol. Cancer Ther. 2015, 14, 2831-2839. [CrossRef] [PubMed]

85. Browaeys-Poly, E.; Blanquart, C.; Perdereau, D.; Antoine, A.F.; Goenaga, D.; Luzy, J.P.; Chen, H.X.; Garbay, C.; Issad, T.; Cailliau, K.; et al. Grb14 inhibits FGF receptor signaling through the regulation of PLC gamma recruitment and activation. FEBS Lett. 2010, 584, 4383-4388. [CrossRef]

86. Cailliau, K.; Perdereau, D.; Lescuyer, A.; Chen, H.X.; Garbay, C.; Vilain, J.P.; Burnol, A.F.; Browaeys-Poly, E. FGF receptor phosphotyrosine 766 is a target for Grb14 to inhibit MDA-MB-231 human breast cancer cell signaling. Anticancer Res. 2005, 25, 3877-3882.

87. Reilly, J.F.; Mickey, G.; Maher, P.A. Association of fibroblast growth factor receptor 1 with the adaptor protein Grb14Characterization of a new receptor binding partner. J. Biol. Chem. 2000, 275, 7771-7778. [CrossRef]

88. Mohapatra, B.; Ahmad, G.; Nadeau, S.; Zutshi, N.; An, W.; Scheffe, S.; Dong, L.; Feng, D.; Goetz, B.; Arya, P.; et al. Protein tyrosine kinase regulation by ubiquitination: Critical roles of Cbl-family ubiquitin ligases. Biochim. Et Biophys. Acta Mol. Cell Res. 2013, 1833, 122-139. [CrossRef]

89. Wong, A.; Lamothe, B.; Li, A.; Schlessinger, J.; Lax, I. FRS2 alpha attenuates FGF receptor signaling by Grb2-mediated recruitment of the ubiquitin ligase Cbl. Proc. Natl. Acad. Sci. USA 2002, 99, 6684-6689. [CrossRef] [PubMed]

90. Dufour, C.; Guenou, H.; Kaabeche, K.; Bouvard, D.; Sanjay, A.; Marie, P.J. FGFR2-Cb1 interaction in lipid rafts triggers attenuation of PI3K/Akt signaling and osteoblast survival. Bone 2008, 42, 1032-1039. [CrossRef] [PubMed]

91. Haugsten, E.M.; Malecki, J.; Bjorklund, S.M.S.; Olsnes, S.; Wesche, J. Ubiquitination of fibroblast growth factor receptor 1 is required for its intracellular sorting but not for its endocytosis. Mol. Biol. Cell 2008, 19, 3390-3403. [CrossRef]

92. Haugsten, E.M.; Sorensen, V.; Brech, A.; Olsnes, S.; Wesche, J. Different intracellular trafficking of FGF1 endocytosed by the four homologous FGF receptors. J. Cell Sci. 2005, 118, 3869-3881. [CrossRef]

93. Belleudi, F.; Leone, L.; Nobili, V.; Raffa, S.; Francescangeli, F.; Maggio, M.; Morrone, S.; Marchese, C.; Torrisi, M.R. Keratinocyte growth factor receptor ligands target the receptor to different intracellular pathways. Traffic 2007, 8, 1854-1872. [CrossRef]

94. Turner, N.; Grose, R. Fibroblast growth factor signalling: From development to cancer. Nat. Rev. Cancer 2010, 10, 116-129. [CrossRef] [PubMed]

95. McNiel, E.A.; Tsichlis, P.N. Analyses of publicly available genomics resources define FGF-2-expressing bladder carcinomas as EMT-prone, proliferative tumors with low mutation rates and high expression of CTLA-4, PD-1 and PD-L1. Signal Transduct. Target. Ther. 2017, 2. [CrossRef] [PubMed]

96. Santolla, M.F.; Vivacqua, A.; Lappano, R.; Rigiracciolo, D.C.; Cirillo, F.; Galli, G.R.; Talia, M.; Brunetti, G.; Miglietta, A.M.; Belfiore, A.; et al. GPER Mediates a Feedforward FGF2/FGFR1 Paracrine Activation Coupling CAFs to Cancer Cells toward Breast Tumor Progression. Cells 2019, 8, 223. [CrossRef] [PubMed]

97. Birck, A.; Kirkin, A.F.; Zeuthen, J.; Hou-Jensen, K. Expression of basic fibroblast growth factor and vascular endothelial growth factor in primary and metastatic melanoma from the same patients. Melanoma Res. 1999, 9, 375-382. [CrossRef]

98. Manousakidi, S.; Guillaume, A.; Pirou, C.; Bouleau, S.; Mignotte, B.; Renaud, F.; Le Floch, N. FGF1 induces resistance to chemotherapy in ovarian granulosa tumor cells through regulation of p53 mitochondrial localization. Oncogenesis $2018,7$. [CrossRef]

99. Awaji, M.; Futakuchi, M.; Heavican, T.; Iqbal, J.; Singh, R.K. Cancer-Associated Fibroblasts Enhance Survival and Progression of the Aggressive Pancreatic Tumor Via FGF-2 and CXCL8. Cancer Microenviron. 2019, 12, 37-46. [CrossRef]

100. Ruotsalainen, T.; Joensuu, H.; Mattson, K.; Salven, P. High pretreatment serum concentration of basic fibroblast growth factor is a predictor of poor prognosis in small cell lung cancer. Cancer Epidemiol. Biomark. Prev. 2002, 11, 1492-1495.

101. Han, D.X.; Wang, M.M.; Yu, Z.K.; Yin, L.; Liu, C.L.; Wang, J.M.; Liu, Y.J.; Jiang, S.Y.; Ren, Z.W.; Yin, J. FGF5 promotes osteosarcoma cells proliferation via activating MAPK signaling pathway. Cancer Manag. Res. 2019, 11, 6457-6466. [CrossRef] [PubMed]

102. Urbini, M.; Indio, V.; Tarantino, G.; Ravegnini, G.; Angelini, S.; Nannini, M.; Saponara, M.; Santini, D.; Ceccarelli, C.; Fiorentino, M.; et al. Gain of FGF4 is a frequent event in KIT/PDGFRA/SDH/RAS-P WT GIST. Genes Chromosomes Cancer 2019, 58, 636-642. [CrossRef]

103. Flavahan, W.A.; Drier, Y.; Johnstone, S.E.; Hemming, M.L.; Tarjan, D.R.; Hegazi, E.; Shareef, S.J.; Javed, N.M.; Raut, C.P.; Eschle, B.K.; et al. Altered chromosomal topology drives oncogenic programs in SDH-deficient GISTs. Nature 2019, 575, 229. [CrossRef] [PubMed]

104. Allerstorfer, S.; Sonvilla, G.; Fischer, H.; Spiegl-Kreinecker, S.; Gauglhofer, C.; Setinek, U.; Czech, T.; Marosi, C.; Buchroithner, J.; Pichler, J.; et al. FGF5 as an oncogenic factor in human glioblastoma multiforme: Autocrine and paracrine activities. Oncogene 2008, 27, 4180-4190. [CrossRef]

105. Huang, T.T.; Wang, L.; Liu, D.; Li, P.; Xiong, H.H.; Zhuang, L.; Sun, L.; Yuan, X.L.; Qiu, H. FGF7/FGFR2 signal promotes invasion and migration in human gastric cancer through upregulation of thrombospondin-1. Int. J. Oncol. 2017, 50, 1501-1512. [CrossRef] [PubMed]

106. Han, T.; Mei, Y.B.; Wang, Y.; Feng, Z.C. miR-5582-5p inhibits cell proliferation of non-small cell lung cancer through targeting FGF-10. Int. J. Clin. Exp. Pathol. 2019, 12, 1087-1094. [PubMed]

107. Liu, H.Y.; Zhao, H.; Li, W.X. Integrated Analysis of Transcriptome and Prognosis Data Identifies FGF22 as a Prognostic Marker of Lung Adenocarcinoma. Technol. Cancer Res. Treat. 2019, 18. [CrossRef] 
108. Nomura, S.; Yoshitomi, H.; Takano, S.; Shida, T.; Kobayashi, S.; Ohtsuka, M.; Kimura, F.; Shimizu, H.; Yoshidome, H.; Kato, A.; et al. FGF10/FGFR2 signal induces cell migration and invasion in pancreatic cancer. Br. J. Cancer 2008, 99, 305-313. [CrossRef] [PubMed]

109. Harpain, F.; Ahmed, M.A.; Hudec, X.; Timelthaler, G.; Jomrich, G.; Mullauer, L.; Selzer, E.; Dorr, W.; Bergmann, M.; Holzmann, K.; et al. FGF8 induces therapy resistance in neoadjuvantly radiated rectal cancer. J. Cancer Res. Clin. Oncol. 2019, 145, 77-86. [CrossRef]

110. Gauglhofer, C.; Sagmeister, S.; Schrottmaier, W.; Fischer, C.; Rodgarkia-Dara, C.; Mohr, T.; Stattner, S.; Bichler, C.; Kandioler, D.; Wrba, F.; et al. Up-Regulation of the Fibroblast Growth Factor 8 Subfamily in Human Hepatocellular Carcinoma for Cell Survival and Neoangiogenesis. Hepatology 2011, 53, 854-864. [CrossRef]

111. Hao, Y.L.; Xiao, Y.X.; Liao, X.Y.; Tang, S.Y.; Xie, X.Y.; Liu, R.; Chen, Q.M. FGF8 induces epithelial-mesenchymal transition and promotes metastasis in oral squamous cell carcinoma. Int. J. Oral Sci. 2021, 13. [CrossRef] [PubMed]

112. Heer, R.; Douglas, D.; Mathers, M.E.; Robson, C.N.; Leung, H.Y. Fibroblast growth factor 17 is over-expressed in human prostate cancer. J. Pathol. 2004, 204, 578-586. [CrossRef] [PubMed]

113. Yang, C.; Zhang, Z.Y.; Ye, F.D.; Mou, Z.Z.; Chen, X.N.; Ou, Y.X.; Xu, C.Y.; Wu, S.Q.; Cheng, Z.; Hu, J.M.; et al. FGF18 Inhibits Clear Cell Renal Cell Carcinoma Proliferation and Invasion via Regulating Epithelial-Mesenchymal Transition. Front. Oncol. 2020, 10. [CrossRef]

114. Mizukami, T.; Togashi, Y.; Naruki, S.; Banno, E.; Terashima, M.; de Velasco, M.A.; Sakai, K.; Yoneshige, A.; Hayashi, H.; Fujita, Y.; et al. Significance of FGF9 gene in resistance to anti-EGFR therapies targeting colorectal cancer: A subset of colorectal cancer patients with FGF9 upregulation may be resistant to anti-EGFR therapies. Mol. Carcinog. 2017, 56, 106-117. [CrossRef] [PubMed]

115. Seitz, T.; Freese, K.; Dietrich, P.; Thasler, W.E.; Bosserhoff, A.; Hellerbrand, C. Fibroblast Growth Factor 9 is expressed by activated hepatic stellate cells and promotes progression of hepatocellular carcinoma. Sci. Rep. 2020, 10. [CrossRef]

116. Teishima, J.; Shoji, K.; Hayashi, T.; Miyamoto, K.; Ohara, S.; Matsubara, A. Relationship between the localization of fibroblast growth factor 9 in prostate cancer cells and postoperative recurrence. Prostate Cancer Prostatic Dis. 2012, 15, 8-14. [CrossRef] [PubMed]

117. Teishima, J.; Yano, S.; Shoji, K.; Hayashi, T.; Goto, K.; Kitano, H.; Oka, K.; Nagamatsu, H.; Matsubara, A. Accumulation of FGF9 in Prostate Cancer Correlates with Epithelial-to-Mesenchymal Transition and Induction of VEGF-A Expression. Anticancer Res. 2014, 34, 695-700.

118. Qian, J.; Tikk, K.; Weigl, K.; Balavarca, Y.; Brenner, H. Fibroblast growth factor 21 as a circulating biomarker at various stages of colorectal carcinogenesis. Br. J. Cancer 2018, 119, 1374-1382. [CrossRef] [PubMed]

119. Cymbaluk-Ploska, A.; Gargulinska, P.; Chudecka-Glaz, A.; Kwiatkowski, S.; Pius-Sadowska, E.; Machalinski, B. The Suitability of FGF21 and FGF23 as New Biomarkers in Endometrial Cancer Patients. Diagnostics 2020, 10, 414. [CrossRef]

120. Kanzaki, H.; Chiba, T.; Ao, J.; Koroki, K.; Kanayama, K.; Maruta, S.; Maeda, T.; Kusakabe, Y.; Kobayashi, K.; Kanogawa, N.; et al. The impact of FGF19/FGFR4 signaling inhibition in antitumor activity of multi-kinase inhibitors in hepatocellular carcinoma. Sci. Rep. 2021, 11, 5303. [CrossRef]

121. Feng, S.; Dakhova, O.; Creighton, C.J.; Ittmann, M. Endocrine Fibroblast Growth Factor FGF19 Promotes Prostate Cancer Progression. Cancer Res. 2013, 73, 2551-2562. [CrossRef] [PubMed]

122. Su, T.H.; Huang, L.L.; Zhang, N.; Peng, S.; Li, X.X.; Wei, G.Y.; Zhai, E.T.; Zeng, Z.R.; Xu, L.X. FGF14 Functions as a Tumor Suppressor through Inhibiting PI3K/AKT/mTOR Pathway in Colorectal Cancer. J. Cancer 2020, 11, 819-825. [CrossRef] [PubMed]

123. Hu, S.; Li, L.; Yeh, S.Y.; Cui, Y.; Li, X.; Chang, H.C.; Jin, J.; Chang, C.S. Infiltrating T cells promote prostate cancer metastasis via modulation of FGF11 -> miRNA-541 -> androgen receptor (AR) -> MMP9 signaling. Mol. Oncol. 2015, 9, 44-57. [CrossRef]

124. Yu, L.; Toriseva, M.; Tuomala, M.; Seikkula, H.; Elo, T.; Tuomela, J.; Kallajoki, M.; Mirtti, T.; Taimen, P.; Bostrom, P.J.; et al Increased expression of fibroblast growth factor 13 in prostate cancer is associated with shortened time to biochemical recurrence after radical prostatectomy. Int. J. Cancer 2016, 139, 140-152. [CrossRef]

125. Johnstone, C.N.; Pattison, A.D.; Harrison, P.F.; Powell, D.R.; Lock, P.; Ernst, M.; Anderson, R.L.; Beilharz, T.H. FGF13 promotes metastasis of triple-negative breast cancer. Int. J. Cancer 2020, 147, 230-243. [CrossRef]

126. Mignatti, P.; Morimoto, T.; Rifkin, D.B. Basic fibroblast growth-factor, a protein devoid of secretory signal sequence, is released by cells via a pathway independent of the endoplasmic-reticulum golgi-complex. J. Cell. Physiol. 1992, 151, 81-93. [CrossRef] [PubMed]

127. Prudovsky, I.; Kumar, T.K.S.; Sterling, S.; Neivandt, D. Protein-Phospholipid Interactions in Nonclassical Protein Secretion: Problem and Methods of Study. Int. J. Mol. Sci. 2013, 14, 3734-3772. [CrossRef]

128. Zhang, Z.; Coomans, C.; David, G. Membrane heparan sulfate proteoglycan-supported FGF2-FGFR1 signaling-Evidence in support of the "cooperative end structures" model. J. Biol. Chem. 2001, 276, 41921-41929. [CrossRef]

129. Aviezer, D.; Hecht, D.; Safran, M.; Eisinger, M.; David, G.; Yayon, A. Perlecan, basal lamina proteoglycan, promotes basic fibroblast growth factor-receptor binding, mitogenesis, and angiogenesis. Cell 1994, 79, 1005-1013. [CrossRef]

130. Mali, M.; Elenius, K.; Miettinen, H.M.; Jalkanen, M. Inhibition of basic fibroblast growth factor-induced growth promotion by overexpression of syndecan-1. J. Biol. Chem. 1993, 268, 24215-24222. [CrossRef]

131. Chang, Z.; Meyer, K.; Rapraeger, A.C.; Friedl, A. Differential ability of heparan sulfate proteoglycans to assemble the fibroblast growth factor receptor complex in situ. FASEB J. 2000, 14, 137-144. [CrossRef] [PubMed] 
132. Steinfeld, R.; Van DenBerghe, H.; David, G. Stimulation of fibroblast growth factor receptor-1 occupancy and signaling by cell surface-associated syndecans and glypican. J. Cell Biol. 1996, 133, 405-416. [CrossRef] [PubMed]

133. Slattery, M.L.; John, E.M.; Stern, M.C.; Herrick, J.; Lundgreen, A.; Giuliano, A.R.; Hines, L.; Baumgartner, K.B.; Torres-Mejia, G.; Wolff, R.K. Associations with growth factor genes (FGF1, FGF2, PDGFB, FGFR2, NRG2, EGF, ERBB2) with breast cancer risk and survival: The Breast Cancer Health Disparities Study. Breast Cancer Res. Treat. 2013, 140, 587-601. [CrossRef] [PubMed]

134. Birrer, M.J.; Johnson, M.E.; Hao, K.; Wong, K.K.; Park, D.C.; Bell, A.; Welch, W.R.; Berkowitz, R.S.; Mok, S.C. Whole genome oligonucleotide-based array comparative genomic hybridization analysis identified fibroblast growth factor I as a prognostic marker for advanced-stage serous ovarian adenocarcinomas. J. Clin. Oncol. 2007, 25, 2281-2287. [CrossRef] [PubMed]

135. Smith, G.; Ng, M.T.H.; Shepherd, L.; Herrington, C.S.; Gourley, C.; Ferguson, M.J.; Wolf, C.R. Individuality in FGF1 expression significantly influences platinum resistance and progression-free survival in ovarian cancer. Br. J. Cancer 2012, 107, 1327-1336. [CrossRef] [PubMed]

136. Sun, Y.Z.; Fan, X.L.; Zhang, Q.; Shi, X.Y.; Xu, G.W.; Zou, C.M. Cancer-associated fibroblasts secrete FGF-1 to promote ovarian proliferation, migration, and invasion through the activation of FGF-1/FGFR4 signaling. Tumor Biol. 2017, 39. [CrossRef] [PubMed]

137. Dongre, A.; Weinberg, R.A. New insights into the mechanisms of epithelial-mesenchymal transition and implications for cancer. Nat. Rev. Mol. Cell Biol. 2019, 20, 69-84. [CrossRef] [PubMed]

138. Giulianelli, S.; Cerliani, J.P.; Lamb, C.A.; Fabris, V.T.; Bottino, M.C.; Gorostiaga, M.A.; Novaro, V.; Gongora, A.; Baldi, A.; Molinolo, A.; et al. Carcinoma-associated fibroblasts activate progesterone receptors and induce hormone independent mammary tumor growth: A role for the FGF-2/FGFR-2 axis. Int. J. Cancer 2008, 123, 2518-2531. [CrossRef] [PubMed]

139. Giulianelli, S.; Riggio, M.; Guillardoy, T.; Pinero, C.P.; Gorostiaga, M.A.; Sequeira, G.; Pataccini, G.; Abascal, M.F.; Toledo, M.F.; Jacobsen, B.M.; et al. FGF2 induces breast cancer growth through ligand-independent activation and recruitment of ER alpha and PRB Delta 4 isoform to MYC regulatory sequences. Int. J. Cancer 2019, 145, 1874-1888. [CrossRef]

140. Shee, K.; Yang, W.; Hinds, J.W.; Hampsch, R.A.; Varn, F.S.; Traphagen, N.A.; Patel, K.; Cheng, C.; Jenkins, N.P.; Kettenbach, A.N.; et al. Therapeutically targeting tumor microenvironment-mediated drug resistance in estrogen receptor-positive breast cancer. $J$. Exp. Med. 2018, 215, 895-910. [CrossRef] [PubMed]

141. Kottakis, F.; Polytarchou, C.; Foltopoulou, P.; Sanidas, I.; Kampranis, S.C.; Tsichlis, P.N. FGF-2 Regulates Cell Proliferation, Migration, and Angiogenesis through an NDY1/KDM2B-miR-101-EZH2 Pathway. Mol. Cell 2011, 43, 285-298. [CrossRef] [PubMed]

142. Zaravinos, A.; Volanis, D.; Lambrou, G.I.; Delakas, D.; Spandidos, D.A. Role of the angiogenic components, VEGFA, FGF2, OPN and RHOC, in urothelial cell carcinoma of the urinary bladder. Oncol. Rep. 2012, 28, 1159-1166. [CrossRef] [PubMed]

143. Ichikawa, K.; Miyano, S.W.; Minoshima, Y.; Matsui, J.; Funahashi, Y. Activated FGF2 signaling pathway in tumor vasculature is essential for acquired resistance to anti-VEGF therapy. Sci. Rep. 2020, 10. [CrossRef]

144. Bisping, G.; Leo, R.; Wenning, D.; Dankbar, B.; Padro, T.; Kropff, M.; Scheffold, C.; Kroger, M.; Mesters, R.M.; Berdel, W.E.; et al. Paracrine interactions of basic fibroblast growth factor and interleukin-6 in multiple myeloma. Blood 2003, 101, 2775-2783. [CrossRef] [PubMed]

145. Aggarwal, V.; Tuli, H.S.; Varol, A.; Thakral, F.; Yerer, M.B.; Sak, K.; Varol, M.; Jain, A.; Khan, A.; Sethi, G. Role of Reactive Oxygen Species in Cancer Progression: Molecular Mechanisms and Recent Advancements. Biomolecules 2019, 9, 735. [CrossRef]

146. Ronca, R.; Ghedini, G.C.; Maccarinelli, F.; Sacco, A.; Locatelli, S.L.; Foglio, E.; Taranto, S.; Grillo, E.; Matarazzo, S.; Castelli, R.; et al. FGF Trapping Inhibits Multiple Myeloma Growth through c-Myc Degradation-Induced Mitochondrial Oxidative Stress. Cancer Res. 2020, 80, 2340-2354. [CrossRef] [PubMed]

147. Pintucci, G.; Quarto, N.; Rifkin, D.B. Methylation of high molecular weight fibroblast growth factor-2 determines post-translational increases in molecular weight and affects its intracellular distribution. Mol. Biol. Cell 1996, 7, 1249-1258. [CrossRef] [PubMed]

148. Wang, F.; Yang, L.J.; Shi, L.; Li, Q.; Zhang, G.S.; Wu, J.L.; Zheng, J.; Jiao, B.H. Nuclear translocation of fibroblast growth factor-2 (FGF2) is regulated by Karyopherin-beta 2 and Ran GTPase in human glioblastoma cells. Oncotarget 2015, 6, 21468-21478. [CrossRef]

149. Joy, A.; Moffett, J.; Neary, K.; Mordechai, E.; Stachowiak, E.K.; Coons, S.; RankinShapiro, J.; Florkiewicz, R.Z.; Stachowiak, M.K. Nuclear accumulation of FGF-2 is associated with proliferation of human astrocytes and glioma cells. Oncogene 1997, 14, 171-183. [CrossRef]

150. Coleman, S.J.; Chioni, A.M.; Ghallab, M.; Anderson, R.K.; Lemoine, N.R.; Kocher, H.M.; Grose, R.P. Nuclear translocation of FGFR1 and FGF2 in pancreatic stellate cells facilitates pancreatic cancer cell invasion. EMBO Mol. Med. 2014, 6, 467-481. [CrossRef]

151. Bong, S.M.; Bae, S.H.; Song, B.; Gwak, H.; Yang, S.W.; Kim, S.; Nam, S.; Rajalingam, K.; Oh, S.J.; Kim, T.W.; et al. Regulation of mRNA export through API5 and nuclear FGF2 interaction. Nucleic Acids Res. 2020, 48, 6340-6352. [CrossRef] [PubMed]

152. Ornitz, D.M.; Xu, J.S.; Colvin, J.S.; McEwen, D.G.; MacArthur, C.A.; Coulier, F.; Gao, G.X.; Goldfarb, M. Receptor specificity of the fibroblast growth factor family. J. Biol. Chem. 1996, 271, 15292-15297. [CrossRef] [PubMed]

153. Muller, H.M.; Steringer, J.P.; Wegehingel, S.; Bleicken, S.; Munster, M.; Dimou, E.; Unger, S.; Weidmann, G.; Andreas, H.; Garcia-Saez, A.J.; et al. Formation of Disulfide Bridges Drives Oligomerization, Membrane Pore Formation, and Translocation of Fibroblast Growth Factor 2 to Cell Surfaces. J. Biol. Chem. 2015, 290, 8925-8937. [CrossRef] [PubMed] 
154. Kwek, S.S.; Roy, R.; Zhou, H.; Climent, J.; Martinez-Climent, J.A.; Fridlyand, J.; Albertson, D.G. Co-amplified genes at 8p12 and $11 \mathrm{q} 13$ in breast tumors cooperate with two major pathways in oncogenesis. Oncogene 2009, 28, 1892-1903. [CrossRef] [PubMed]

155. Helsten, T.; Schwaederle, M.; Kurzrock, R. Fibroblast growth factor receptor signaling in hereditary and neoplastic disease: Biologic and clinical implications. Cancer Metastasis Rev. 2015, 34, 479-496. [CrossRef]

156. Yasuda, K.; Torigoe, T.; Mariya, T.; Asano, T.; Kuroda, T.; Matsuzaki, J.; Ikeda, K.; Yamauchi, M.; Emori, M.; Asanuma, H.; et al. Fibroblasts induce expression of FGF4 in ovarian cancer stem-like cells/cancer-initiating cells and upregulate their tumor initiation capacity. Lab. Investig. 2014, 94, 1355-1369. [CrossRef]

157. Zhang, X.Q.; Ibrahimi, O.A.; Olsen, S.K.; Umemori, H.; Mohammadi, M.; Ornitz, D.M. Receptor specificity of the fibroblast growth factor family-The complete mammalian FGF family. J. Biol. Chem. 2006, 281, 15694-15700. [CrossRef] [PubMed]

158. Yeh, B.K.; Igarashi, M.; Eliseenkova, A.V.; Plotnikov, A.N.; Sher, I.; Ron, D.; Aaronson, S.A.; Mohammadi, M. Structural basis by which alternative splicing confers specificity in fibroblast growth factor receptors. Proc. Natl. Acad. Sci. USA 2003, 100, $2266-2271$. [CrossRef]

159. Zinkle, A.; Mohammadi, M. Structural Biology of the FGF7 Subfamily. Front. Genet. 2019, 10. [CrossRef]

160. Watson, J.; Francavilla, C. Regulation of FGF10 signaling in development and disease. Front. Genet. 2018, 9, 500. [CrossRef]

161. Sunmonu, N.A.; Li, K.R.; Li, J.Y.H. Numerous Isoforms of Fgf8 Reflect Its Multiple Roles in the Developing Brain. J. Cell. Physiol. 2011, 226, 1722-1726. [CrossRef] [PubMed]

162. Miyamoto, M.; Naruo, K.; Seko, C.; Matsumoto, S.; Kondo, T.; Kurokawa, T. Molecular-cloning of a novel cytokine cdna-encoding the 9 th member of the fibroblast growth-factor family, which has a unique secretion property. Mol. Cell. Biol. 1993, 13, 4251-4259. [CrossRef] [PubMed]

163. Miyake, A.; Konishi, M.; Martin, F.H.; Hernday, N.A.; Ozaki, K.; Yamamoto, S.; Mikami, T.; Arakawa, T.; Itoh, N. Structure and expression of a novel member, FGF-16, of the fibroblast growth factor family. Biochem. Biophys. Res. Commun. 1998, 243, 148-152. [CrossRef] [PubMed]

164. Jeffers, M.; Shimkets, R.; Prayaga, S.; Boldog, F.; Yang, M.J.; Burgess, C.; Fernandes, E.; Rittman, B.; Shimkets, J.; LaRochelle, W.J.; et al. Identification of a novel human fibroblast growth factor and characterization of its role in oncogenesis. Cancer Res. 2001, 61, 3131-3138. [PubMed]

165. Miyakawa, K.; Hatsuzawa, K.; Kurokawa, T.; Asada, M.; Kuroiwa, T.; Imamura, T. A hydrophobic region locating at the center of fibroblast growth factor-9 is crucial for its secretion. J. Biol. Chem. 1999, 274, 29352-29357. [CrossRef]

166. Miyakawa, K.; Imamura, T. Secretion of FGF-16 requires an uncleaved bipartite signal sequence. J. Biol. Chem. 2003, 278, 35718-35724. [CrossRef]

167. Shi, S.Y.; Lu, Y.W.; Richardson, J.; Min, X.S.; Weiszmann, J.; Richards, W.G.; Wang, Z.L.; Zhang, Z.Q.; Zhang, J.; Li, Y. A systematic dissection of sequence elements determining beta-Klotho and FGF interaction and signaling. Sci. Rep. 2018, 8. [CrossRef]

168. Suzuki, M.; Uehara, Y.; Motomura-Matsuzaka, K.; Oki, J.; Koyama, Y.; Kimura, M.; Asada, M.; Komi-Kuramochi, A.; Oka, S.; Imamura, T. Beta Klotho is required for fibroblast growth factor (FGF) 21 signaling through FGF receptor (FGFR) 1c and FGFR3c. Mol. Endocrinol. 2008, 22, 1006-1014. [CrossRef]

169. Kim, H.J.; Kim, K.H.; Lee, J.; Oh, J.J.; Cheong, H.S.; Wong, E.L.; Yang, B.S.; Byun, S.S.; Myung, S.C. Single nucleotide polymorphisms in fibroblast growth factor 23 gene, FGF23, are associated with prostate cancer risk. BJU Int. 2014, 114, 303-310. [CrossRef] [PubMed]

170. Mansinho, A.; Ferreira, A.R.; Casimiro, S.; Alho, I.; Vendrell, I.; Costa, A.L.; Sousa, R.; Abreu, C.; Pulido, C.; Macedo, D.; et al. Levels of Circulating Fibroblast Growth Factor 23 (FGF23) and Prognosis in Cancer Patients with Bone Metastases. Int. J. Mol. Sci. 2019, 20, 695. [CrossRef]

171. Smallwood, P.M.; MunozSanjuan, I.; Tong, P.; Macke, J.P.; Hendry, S.H.C.; Gilbert, D.J.; Copeland, N.G.; Jenkins, N.A.; Nathans, J. Fibroblast growth factor (FGF) homologous factors: New members of the FGF family implicated in nervous system development. Proc. Natl. Acad. Sci. USA 1996, 93, 9850-9857. [CrossRef]

172. Liu, C.J.; Dib-Hajj, S.D.; Waxman, S.G. Fibroblast growth factor homologous factor $1 \mathrm{~B}$ binds to the $\mathrm{C}$ terminus of the tetrodotoxinresistant sodium channel $\mathrm{rNa}(\mathrm{v}) 1.9 \mathrm{a}(\mathrm{NaN})$. J. Biol. Chem. 2001, 276, 18925-18933. [CrossRef]

173. Olsen, S.K.; Garbi, M.; Zampieri, N.; Eliseenkova, A.V.; Ornitz, D.M.; Goldfarb, M.; Mohammadi, M. Fibroblast growth factor (FGF) homologous factors share structural but not functional homology with FGFs. J. Biol. Chem. 2003, 278, 34226-34236. [CrossRef] [PubMed]

174. Sochacka, M.; Opalinski, L.; Szymczyk, J.; Zimoch, M.B.; Czyrek, A.; Krowarsch, D.; Otlewski, J.; Zakrzewska, M. FHF1 is a bona fide fibroblast growth factor that activates cellular signaling in FGFR-dependent manner. Cell Commun. Signal. $2020,18$. [CrossRef]

175. Lin, H.P.; Lu, P.Y.; Zhou, M.; Wu, F.F.; Weng, L.; Meng, K.K.; Yang, D.; Li, S.J.; Jiang, C.; Tian, H.S. Purification of recombinant human fibroblast growth factor 13 in E. coli and its molecular mechanism of mitogenesis. Appl. Microbiol. Biotechnol. 2019, 103, 7017-7027. [CrossRef]

176. Courjal, F.; Cuny, M.; SimonyLafontaine, J.; Louason, G.; Speiser, P.; Zeillinger, R.; Rodriguez, C.; Theillet, C. Mapping of DNA amplifications at 15 chromosomal localizations in 1875 breast tumors: Definition of phenotypic groups. Cancer Res. 1997, 57, 4360-4367. [PubMed] 
177. Cuny, M.; Kramar, A.; Courjal, F.; Johannsdottir, V.; Iacopetta, B.; Fontaine, H.; Grenier, J.; Culine, S.; Theillet, C. Relating genotype and phenotype in breast cancer: An analysis of the prognostic significance of amplification at eight different genes or loci and of p53 mutations. Cancer Res. 2000, 60, 1077-1083. [PubMed]

178. Mo, J.; Wen, X.; Kim, T.S.; Kwak, Y.; Cho, N.Y.; Lee, H.S.; Kang, G.H. Fibroblast Growth Factor Receptor 1 (FGFR1) Amplification Detected by Droplet Digital Polymerase Chain Reaction (ddPCR) Is a Prognostic Factor in Colorectal Cancers. Cancer Res. Treat. 2020, 52, 74-84. [CrossRef]

179. Goke, F.; Goke, A.; von Massenhausen, A.; Franzen, A.; Sharma, R.; Kirsten, R.; Bohm, D.; Kristiansen, G.; Stenzinger, A.; Wynes, M.; et al. Fibroblast Growth Factor Receptor 1 as a Putative Therapy Target in Colorectal Cancer. Digestion 2013, 88, 172-181. [CrossRef]

180. Astolfi, A.; Pantaleo, M.A.; Indio, V.; Urbini, M.; Nannini, M. The Emerging Role of the FGF/FGFR Pathway in Gastrointestinal Stromal Tumor. Int. J. Mol. Sci. 2020, 21, 3313. [CrossRef]

181. Singh, D.; Chan, J.M.; Zoppoli, P.; Niola, F.; Sullivan, R.; Castano, A.; Liu, E.M.; Reichel, J.; Porrati, P.; Pellegatta, S.; et al. Transforming Fusions of FGFR and TACC Genes in Human Glioblastoma. Science 2012, 337, 1231-1235. [CrossRef]

182. Trisolini, E.; El Wardighi, D.; Giry, M.; Bernardi, P.; Boldorini, R.L.; Mokhtari, K.; Sanson, M. Actionable FGFR1 and BRAF mutations in adult circumscribed gliomas. J. Neuro Oncol. 2019, 145, 241-245. [CrossRef] [PubMed]

183. Freier, K.; Schwaenen, C.; Sticht, C.; Flechtenmacher, C.; Muhling, J.; Hofele, C.; Radlwimmer, B.; Lichter, P.; Joos, S. Recurrent FGFR 1 amplification and high FGFR1 protein expression in oral squamous cell carcinoma (OSCC). Oral. Oncol. 2007, 43, 60-66. [CrossRef] [PubMed]

184. Weiss, J.; Sos, M.L.; Seidel, D.; Peifer, M.; Zander, T.; Heuckmann, J.M.; Ullrich, R.T.; Menon, R.; Maier, S.; Soltermann, A.; et al. Frequent and Focal FGFR1 Amplification Associates with Therapeutically Tractable FGFR1 Dependency in Squamous Cell Lung Cancer. Sci. Transl. Med. 2010, 2. [CrossRef] [PubMed]

185. Cihoric, N.; Savic, S.; Schneider, S.; Ackermann, I.; Bichsel-Naef, M.; Schmid, R.A.; Lardinois, D.; Gugger, M.; Bubendorf, L.; Zlobec, I.; et al. Prognostic role of FGFR1 amplification in early-stage non-small cell lung cancer. Br. J. Cancer 2014, 110, $2914-2922$. [CrossRef]

186. Peifer, M.; Fernandez-Cuesta, L.; Sos, M.L.; George, J.; Seidel, D.; Kasper, L.H.; Plenker, D.; Leenders, F.; Sun, R.P.; Zander, T.; et al. Integrative genome analyses identify key somatic driver mutations of small-cell lung cancer. Nat. Genet. 2012, 44,1104 . [CrossRef]

187. Ding, L.; Getz, G.; Wheeler, D.A.; Mardis, E.R.; McLellan, M.D.; Cibulskis, K.; Sougnez, C.; Greulich, H.; Muzny, D.M.; Morgan, M.B.; et al. Somatic mutations affect key pathways in lung adenocarcinoma. Nature 2008, 455, 1069-1075. [CrossRef]

188. Miao, J.L.; Zhou, J.H.; Cai, J.J.; Liu, R.J. The association between fibroblast growth factor receptor 1 gene amplification and lung cancer: A meta-analysis. Arch. Med. Sci. 2020, 16, 16-26. [CrossRef]

189. Helsten, T.; Elkin, S.; Arthur, E.; Tomson, B.N.; Carter, J.; Kurzrock, R. The FGFR Landscape in Cancer: Analysis of 4853 Tumors by Next-Generation Sequencing. Clin. Cancer Res. 2016, 22, 259-267. [CrossRef]

190. Lehnen, N.C.; von Massenhausen, A.; Kalthoff, H.; Zhou, H.; Glowka, T.; Schutte, U.; Holler, T.; Riesner, K.; Boehm, D.; Merkelbach-Bruse, S.; et al. Fibroblast growth factor receptor 1 gene amplification in pancreatic ductal adenocarcinoma. Histopathology 2013, 63, 157-166. [CrossRef]

191. Yan, G.C.; Fukabori, Y.; McBride, G.; Nikolaropolous, S.; McKeehan, W.L. Exon switching and activation of stromal and embryonic fibroblast growth-factor (FGF)-FGF receptor genes in prostate epithelial-cells accompany stromal independence and malignancy. Mol. Cell. Biol. 1993, 13, 4513-4522. [CrossRef] [PubMed]

192. Jin, C.L.; McKeehan, K.; Guo, W.; Jamna, S.; Ittmann, M.M.; Foster, B.; Greenberg, N.M.; McKeehan, W.L.; Wang, F. Cooperation between ectopic FGFR1 and depression of FGFR2 in induction of prostatic intraepithelial neoplasia in the mouse prostate. Cancer Res. 2003, 63, 8784-8790.

193. Wang, F.; McKeehan, K.; Yu, C.D.; Ittmann, M.; McKeehan, W.L. Chronic activity of ectopic type I fibroblast growth factor receptor tyrosine kinase in prostate epithelium results in hyperplasia accompanied by intraepithelial neoplasia. Prostate 2004, 58, 1-12. [CrossRef] [PubMed]

194. Wang, C.; Ke, Y.P.; Liu, S.Y.; Pan, S.R.; Liu, Z.Y.; Zhang, H.; Fan, Z.C.; Zhou, C.Y.; Liu, J.C.; Wang, F. Ectopic fibroblast growth factor receptor 1 promotes inflammation by promoting nuclear factor-kappa B signaling in prostate cancer cells. J. Biol. Chem. 2018, 293, 14839-14849. [CrossRef] [PubMed]

195. Schultheis, A.M.; Bos, M.; Schmitz, K.; Wilsberg, L.; Binot, E.; Wolf, J.; Buttner, R.; Schildhaus, H.U. Fibroblast growth factor receptor 1 (FGFR1) amplification is a potential therapeutic target in small-cell lung cancer. Mod. Pathol. 2014, $27,214-221$. [CrossRef]

196. George, J.; Lim, J.S.; Jang, S.J.; Cun, Y.P.; Ozretic, L.; Kong, G.; Leenders, F.; Lu, X.; Fernandez-Cuesta, L.; Bosco, G.; et al. Comprehensive genomic profiles of small cell lung cancer. Nature 2015, 524, 47-53. [CrossRef]

197. Kim, K.B.; Kim, Y.; Rivard, C.J.; Kim, D.W.; Park, K.S. FGFR1 Is Critical for RBL2 Loss-Driven Tumor Development and Requires PLCG1 Activation for Continued Growth of Small Cell Lung Cancer. Cancer Res. 2020, 80, 5051-5062. [CrossRef]

198. Lei, H.P.; Deng, C.X. Fibroblast Growth Factor Receptor 2 Signaling in Breast Cancer. Int. J. Biol. Sci. 2017, $13,1163-1171$. [CrossRef] 
199. Jain, A.; Borad, M.J.; Kelley, R.K.; Wang, Y.; Abdel-Wahab, R.; Meric-Bernstam, F.; Baggerly, K.A.; Kaseb, A.O.; Al-Shamsi, H.O.; Ahn, D.H.; et al. Cholangiocarcinoma With FGFR Genetic Aberrations: A Unique Clinical Phenotype. JCO Precis. Oncol. 2018, 2, 1-12. [CrossRef]

200. Lowery, M.A.; Ptashkin, R.; Jordan, E.; Berger, M.F.; Zehir, A.; Capanu, M.; Kemeny, N.E.; O’Reilly, E.M.; El-Dika, I.; Jarnagin, W.R.; et al. Comprehensive Molecular Profiling of Intrahepatic and Extrahepatic Cholangiocarcinomas: Potential Targets for Intervention. Clin. Cancer Res. 2018, 24, 4154-4161. [CrossRef]

201. Ross, J.S.; Wang, K.; Gay, L.; Al-Rohil, R.; Rand, J.V.; Jones, D.M.; Lee, H.J.; Sheehan, C.E.; Otto, G.A.; Palmer, G.; et al. New Routes to Targeted Therapy of Intrahepatic Cholangiocarcinomas Revealed by Next-Generation Sequencing. Oncologist 2014, 19, 235-242. [CrossRef] [PubMed]

202. Jeske, Y.W.; Ali, S.; Byron, S.A.; Gao, F.; Mannel, R.S.; Ghebre, R.G.; DiSilvestro, P.A.; Lele, S.B.; Pearl, M.L.; Schmidt, A.P.; et al. FGFR2 mutations are associated with poor outcomes in endometrioid endometrial cancer: An NRG Oncology/Gynecologic Oncology Group study. Gynecol. Oncol. 2017, 145, 366-373. [CrossRef] [PubMed]

203. Su, X.; Zhan, P.; Gavine, P.R.; Morgan, S.; Womack, C.; Ni, X.; Shen, D.; Bang, Y.J.; Im, S.A.; Kim, W.H.; et al. FGFR2 amplification has prognostic significance in gastric cancer: Results from a large international multicentre study. Br. J. Cancer 2014, 110, 967-975. [CrossRef] [PubMed]

204. Jang, J.H.; Shin, K.H.; Park, J.G. Mutations in fibroblast growth factor receptor 2 and fibroblast growth factor receptor 3 genes associated with human gastric and colorectal cancers. Cancer Res. 2001, 61, 3541-3543. [PubMed]

205. Liao, R.G.; Jung, J.; Tchaicha, J.; Wilkerson, M.D.; Sivachenko, A.; Beauchamp, E.M.; Liu, Q.S.; Pugh, T.J.; Pedamallu, C.S.; Hayes, D.N.; et al. Inhibitor-Sensitive FGFR2 and FGFR3 Mutations in Lung Squamous Cell Carcinoma. Cancer Res. 2013, 73, 5195-5205. [CrossRef]

206. Fischbach, A.; Rogler, A.; Erber, R.; Stoehr, R.; Poulsom, R.; Heidenreich, A.; Schneevoigt, B.S.; Hauke, S.; Hartmann, A.; Knuechel, R.; et al. Fibroblast growth factor receptor (FGFR) gene amplifications are rare events in bladder cancer. Histopathology 2015, 66, 639-649. [CrossRef]

207. Guancial, E.A.; Werner, L.; Bellmunt, J.; Bamias, A.; Choueiri, T.K.; Ross, R.; Schutz, F.A.; Park, R.S.; O’Brien, R.J.; Hirsch, M.S.; et al. FGFR3 expression in primary and metastatic urothelial carcinoma of the bladder. Cancer Med. 2014, 3, 835-844. [CrossRef]

208. Hammam, O.; Aboushousha, T.; El-Hindawi, A.; Khairy, H.; Khalil, H.; Kamel, A.; Akl, M.; Abdel-Hady, A.; Magdy, M.; Badawy, M.; et al. Expression of FGFR3 Protein and Gene Amplification in Urinary Bladder Lesions in Relation to Schistosomiasis. Open Access Maced. J. Med. Sci. 2017, 5, 160-166. [CrossRef]

209. Cappellen, D.; De Oliveira, C.; Ricol, D.; de Medina, S.G.D.; Bourdin, J.; Sastre-Garau, X.; Chopin, D.; Thiery, J.P.; Radvanyi, F. Frequent activating mutations of FGFR3 in human bladder and cervix carcinomas. Nat. Genet. 1999, 23, 18-20. [CrossRef]

210. Sfakianos, J.P.; Cha, E.K.; Iyer, G.; Scott, S.N.; Zabor, E.C.; Shah, R.H.; Ren, Q.; Bagrodia, A.; Kim, P.H.; Hakimi, A.A.; et al. Genomic Characterization of Upper Tract Urothelial Carcinoma. Eur. Urol. 2015, 68, 970-977. [CrossRef]

211. Robinson, B.D.; Vlachostergios, P.J.; Bhinder, B.; Liu, W.S.; Li, K.; Moss, T.J.; Bareja, R.; Park, K.; Tavassoli, P.; Cyrta, J.; et al. Upper tract urothelial carcinoma has a luminal-papillary T-cell depleted contexture and activated FGFR3 signaling. Nat. Commun. 2019, 10. [CrossRef] [PubMed]

212. Teo, M.Y.; Mota, J.M.; Whiting, K.A.; Li, H.A.; Funt, S.A.; Lee, C.H.; Solit, D.B.; Al-Ahmadie, H.; Milowsky, M.I.; Balar, A.V.; et al. Fibroblast Growth Factor Receptor 3 Alteration Status is Associated with Differential Sensitivity to Platinum-based Chemotherapy in Locally Advanced and Metastatic Urothelial Carcinoma. Eur. Urol. 2020, 78, 907-915. [CrossRef] [PubMed]

213. Agarwal, N.; Pal, S.K.; Hahn, A.W.; Nussenzveig, R.H.; Pond, G.R.; Gupta, S.V.; Wang, J.; Bilen, M.A.; Naik, G.; Ghatalia, P.; et al. Characterization of Metastatic Urothelial Carcinoma via Comprehensive Genomic Profiling of Circulating Tumor DNA. Cancer 2018, 124, 2115-2124. [CrossRef] [PubMed]

214. Robertson, A.G.; Kim, J.; Al-Ahmadie, H.; Bellmunt, J.; Guo, G.W.; Cherniack, A.D.; Hinoue, T.; Laird, P.W.; Hoadley, K.A.; Akbani, R.; et al. Comprehensive Molecular Characterization of Muscle-Invasive Bladder Cancer. Cell 2017, 171, 540. [CrossRef]

215. Carneiro, B.A.; Elvin, J.A.; Kamath, S.D.; Ali, S.M.; Paintal, A.S.; Restrepoe, A.; Berry, E.; Giles, F.J.; Johnson, M.L. FGFR3-TACC3: A novel gene fusion in cervical cancer. Gynecol. Oncol. Rep. 2015, 13, 53-56. [CrossRef]

216. Tamura, R.; Yoshihara, K.; Saito, T.; Ishimura, R.; Martinez-Ledesma, J.E.; Xin, H.; Ishiguro, T.; Mori, Y.; Yamawaki, K.; Suda, K.; et al. Novel therapeutic strategy for cervical cancer harboring FGFR3-TACC3 fusions. Oncogenesis 2018, 7. [CrossRef]

217. Qin, A.; Johnson, A.; Ross, J.S.; Miller, V.A.; Ali, S.M.; Schrock, A.B.; Gadgeel, S.M. Detection of Known and Novel FGFR Fusions in Non-Small Cell Lung Cancer by Comprehensive Genomic Profiling. J. Thorac. Oncol. 2019, 14, 54-62. [CrossRef]

218. Wang, R.; Wang, L.; Li, Y.; Hu, H.C.; Shen, L.; Shen, X.X.; Pan, Y.J.; Ye, T.; Zhang, Y.; Luo, X.Y.; et al. FGFR1/3 Tyrosine Kinase Fusions Define a Unique Molecular Subtype of Non-Small Cell Lung Cancer. Clin. Cancer Res. 2014, 20, 4107-4114. [CrossRef]

219. Brito, L.P.; Ribeiro, T.C.; Almeida, M.Q.; Jorge, A.A.D.; Soares, I.C.; Latronico, A.C.; Mendonca, B.B.; Fragoso, M.; Lerario, A.M. The role of fibroblast growth factor receptor 4 overexpression and gene amplification as prognostic markers in pediatric and adult adrenocortical tumors. Endocr. Relat. Cancer 2012, 19, L11-L13. [CrossRef]

220. Yang, W.; Yao, Y.W.; Zeng, J.L.; Liang, W.J.; Wang, L.; Bai, C.Q.; Liu, C.H.; Song, Y. Prognostic value of FGFR1 gene copy number in patients with non-small cell lung cancer: A meta-analysis. J. Thorac. Dis. 2014, 6, 803-809. [CrossRef]

221. Heist, R.S.; Mino-Kenudson, M.; Sequist, L.V.; Tammireddy, S.; Morrissey, L.; Christiani, D.C.; Engelman, J.A.; Iafrate, A.J. FGFR1 Amplification in Squamous Cell Carcinoma of The Lung. J. Thorac. Oncol. 2012, 7, 1775-1780. [CrossRef] 
222. Giacomini, A.; Taranto, S.; Rezzola, S.; Matarazzo, S.; Grillo, E.; Bugatti, M.; Scotuzzi, A.; Guerra, J.; Di Trani, M.; Presta, M.; et al. Inhibition of the FGF/FGFR System Induces Apoptosis in Lung Cancer Cells via c-Myc Downregulation and Oxidative Stress. Int. J. Mol. Sci. 2020, 21, 9376. [CrossRef]

223. Turner, N.; Pearson, A.; Sharpe, R.; Lambros, M.; Geyer, F.; Lopez-Garcia, M.A.; Natrajan, R.; Marchio, C.; Iorns, E.; Mackay, A.; et al. FGFR1 Amplification Drives Endocrine Therapy Resistance and Is a Therapeutic Target in Breast Cancer. Cancer Res. 2010, 70, 2085-2094. [CrossRef] [PubMed]

224. Reis, J.S.; Simpson, P.T.; Turner, N.C.; Lambros, M.B.; Jones, C.; Mackay, A.; Grigoriadis, A.; Sarrio, D.; Savage, K.; Dexter, T.; et al. FGFR1 emerges as a potential therapeutic target for lobular breast carcinomas. Clin. Cancer Res. 2006, 12, 6652-6662. [CrossRef]

225. Gelsi-Boyer, W.; Orsetti, B.; Cervera, N.; Finetti, P.; Sircoulomb, F.; Rouge, C.; Lasorsa, L.; Letessier, A.; Ginestier, C.; Monville, F.; et al. Comprehensive profiling of 8p11-12 amplification in breast cancer. Mol. Cancer Res. 2005, 3, 655-667. [CrossRef] [PubMed]

226. Edwards, J.; Krishna, S.; Witton, C.J.; Bartlett, J.M.S. Gene amplifications associated with the development of hormone-resistant prostate cancer. Clin. Cancer Res. 2003, 9, 5271-5281.

227. Ishiwata, T.; Matsuda, Y.; Yamamoto, T.; Uchida, E.; Korc, M.; Naito, Z. Enhanced Expression of Fibroblast Growth Factor Receptor 2 IIIc Promotes Human Pancreatic Cancer Cell Proliferation. Am. J. Pathol. 2012, 180, 1928-1941. [CrossRef]

228. Kornmann, M.; Ishiwata, T.; Matsuda, K.; Lopez, M.E.; Fukahi, K.; Asano, G.; Beger, H.G.; Korc, M. IIIc isoform of fibroblast growth factor receptor 1 is overexpressed in human pancreatic cancer and enhances tumorigenicity of hamster ductal cells. Gastroenterology 2002, 123, 301-313. [CrossRef] [PubMed]

229. Hur, J.Y.; Chao, J.; Kim, K.; Kim, S.T.; Kim, K.M.; Klempner, S.J.; Lee, J. High-level FGFR2 amplification is associated with poor prognosis and Lower response to chemotherapy in gastric cancers. Pathol. Res. Pract. 2020, 216. [CrossRef] [PubMed]

230. De Luca, A.; Abate, R.E.; Rachiglio, A.M.; Maiello, M.R.; Esposito, C.; Schettino, C.; Izzo, F.; Nasti, G.; Normanno, N. FGFR Fusions in Cancer: From Diagnostic Approaches to Therapeutic Intervention. Int. J. Mol. Sci. 2020, 21, 6856. [CrossRef]

231. Arai, Y.; Totoki, Y.; Hosoda, F.; Shirota, T.; Hama, N.; Nakamura, H.; Ojima, H.; Furuta, K.; Shimada, K.; Okusaka, T.; et al. Fibroblast Growth Factor Receptor 2 Tyrosine Kinase Fusions Define a Unique Molecular Subtype of Cholangiocarcinoma. Hepatology 2014, 59, 1427-1434. [CrossRef] [PubMed]

232. Patani, H.; Bunney, T.D.; Thiyagarajan, N.; Norman, R.A.; Ogg, D.; Breed, J.; Ashford, P.; Potterton, A.; Edwards, M.; Williams, S.V.; et al. Landscape of activating cancer mutations in FGFR kinases and their differential responses to inhibitors in clinical use. Oncotarget 2016, 7, 24252-24268. [CrossRef]

233. Gergely, F.; Karlsson, C.; Still, I.; Cowell, J.; Kilmartin, J.; Raff, J.W. The TACC domain identifies a family of centrosomal proteins that can interact with microtubules. Proc. Natl. Acad. Sci. USA 2000, 97, 14352-14357. [CrossRef]

234. Jaakkola, S.; Salmikangas, P.; Nylund, S.; Partanen, J.; Armstrong, E.; Pyrhonen, S.; Lehtovirta, P.; Nevanlinna, H. Amplification of FGFR4 gene in human breast and gynecological cancers. Int. J. Cancer 1993, 54, 378-382. [CrossRef] [PubMed]

235. Bange, J.; Prechtl, D.; Cheburkin, Y.; Specht, K.; Harbeck, N.; Schmitt, M.; Knyazeva, T.; Muller, S.; Gartner, S.; Sures, I.; et al. Cancer progression and tumor cell motility are associated with the FGFR4 Arg(388) allele. Cancer Res. 2002, 62, 840-847. [PubMed]

236. Frullanti, E.; Berking, C.; Harbeck, N.; Jezequel, P.; Haugen, A.; Mawrin, C.; Parise, O.; Sasaki, H.; Tsuchiya, N.; Dragani, T.A.; et al. Meta and pooled analyses of FGFR4 Gly388Arg polymorphism as a cancer prognostic factor. Eur. J. Cancer Prev. 2011, 20, 340-347. [CrossRef] [PubMed]

237. Peng, T.; Sun, Y.Y.; Lv, Z.W.; Zhang, Z.; Su, Q.X.; Wu, H.; Zhang, W.; Yuan, W.; Zuo, L.; Shi, L.; et al. Effects of FGFR4 G388R, V10I polymorphisms on the likelihood of cancer. Sci. Rep. 2021, 11. [CrossRef]

238. Yang, X.C.; Steinberg, F.; Zhuang, L.; Bessey, R.; Trueb, B. Receptor FGFRL1 does not promote cell proliferation but induces cell adhesion. Int. J. Mol. Med. 2016, 38, 30-38. [CrossRef]

239. Rieckmann, T.; Kotevic, I.; Trueb, B. The cell surface receptor FGFRL1 forms constitutive dimers that promote cell adhesion. Exp. Cell Res. 2008, 314, 1071-1081. [CrossRef]

240. Nurcombe, V.; Smart, C.E.; Chipperfield, H.; Cool, S.M.; Boilly, B.; Hondermarck, H. The proliferative and migratory activities of breast cancer cells can be differentially regulated by heparan sulfates. J. Biol. Chem. 2000, 275, 30009-30018. [CrossRef]

241. Gotte, M.; Kersting, C.; Radke, I.; Kiesel, L.; Wulfing, P. An expression signature of syndecan-1 (CD138), E-cadherin and c-met is associated with factors of angiogenesis and lymphangiogenesis in ductal breast carcinoma in situ. Breast Cancer Res. 2007, 9. [CrossRef] [PubMed]

242. Mundhenke, C.; Meyer, K.; Drew, S.; Friedl, A. Heparan sulfate proteoglycans as regulators of fibroblast growth factor-2 receptor binding in breast carcinomas. Am. J. Pathol. 2002, 160, 185-194. [CrossRef]

243. Wu, X.C.; Kan, M.K.; Wang, F.; Jin, C.L.; Yu, C.D.; McKeehan, W.L. A rare premalignant prostate tumor epithelial cell syndecan-1 forms a fibroblast growth factor-binding complex with progression-promoting ectopic fibroblast growth factor receptor 1 . Cancer Res. 2001, 61, 5295-5302.

244. Filla, M.S.; Dam, P.; Rapraeger, A.C. The cell surface proteoglycan syndecan-1 mediates fibroblast growth factor-2 binding and activity. J. Cell. Physiol. 1998, 174, 310-321. [CrossRef]

245. Zong, F.; Fthenou, E.; Wolmer, N.; Hollosi, P.; Kovalszky, I.; Szilak, L.; Mogler, C.; Nilsonne, G.; Tzanakakis, G.; Dobra, K. Syndecan-1 and FGF-2, but Not FGF Receptor-1, Share a Common Transport Route and Co-Localize with Heparanase in the Nuclei of Mesenchymal Tumor Cells. PLoS ONE 2009, 4. [CrossRef] [PubMed]

246. Qiao, D.H.; Meyer, K.; Mundhenke, C.; Drew, S.A.; Friedl, A. Heparan sulfate proteoglycans as regulators of fibroblast growth factor-2 signaling in brain endothelial cells. J. Biol. Chem. 2003, 278, 16045-16053. [CrossRef] [PubMed] 
247. Sachdeva, A.; Gouge, J.; Kontovounisios, C.; Nikolaou, S.; Ashworth, A.; Lim, K.; Chong, I.E. Klotho and the Treatment of Human Malignancies. Cancers 2020, 12, 1665. [CrossRef] [PubMed]

248. Wolf, I.; Levanon-Cohen, S.; Bose, S.; Ligumsky, H.; Sredni, B.; Kanety, H.; Kuro-o, M.; Karlan, B.; Kaufman, B.; Koeffler, H.P.; et al. Klotho: A tumor suppressor and a modulator of the IGF-1 and FGF pathways in human breast cancer. Oncogene 2008, 27, 7094-7105. [CrossRef]

249. Lee, S.; Choi, J.; Mohanty, J.; Sousa, L.P.; Tome, F.; Pardon, E.; Steyaert, J.; Lemmon, M.A.; Lax, I.; Schlessinger, J. Structures of beta-klotho reveal a 'zip code'-like mechanism for endocrine FGF signalling. Nature 2018, 553, 501. [CrossRef]

250. Li, F.; Li, Z.M.; Han, Q.; Cheng, Y.R.; Ji, W.X.; Yang, Y.; Lu, S.; Xia, W.L. Enhanced autocrine FGF19/FGFR4 signaling drives the progression of lung squamous cell carcinoma, which responds to mTOR inhibitor AZD2104. Oncogene 2020, 39, $3507-3521$. [CrossRef]

251. Poh, W.J.; Wong, W.N.; Ong, H.M.; Aung, M.O.; Lim, S.G.; Chua, B.T.; Ho, H.K. Klotho-beta overexpression as a novel target for suppressing proliferation and fibroblast growth factor receptor-4 signaling in hepatocellular carcinoma. Mol. Cancer $2012,11$. [CrossRef] [PubMed]

252. Cui, G.Z.; Martin, R.C.; Jin, H.; Liu, X.K.; Pandit, H.; Zhao, H.J.; Cai, L.; Zhang, P.; Li, W.; Li, Y. Up-regulation of FGF15/19 signaling promotes hepatocellular carcinoma in the background of fatty liver. J. Exp. Clin. Cancer Res. 2018, 37. [CrossRef] [PubMed]

253. Lin, Z.Z.; Hsu, C.; Jeng, Y.M.; Hu, F.C.; Pan, H.W.; Wu, Y.M.; Hsu, H.C.; Cheng, A.L. Klotho-beta and fibroblast growth factor 19 expression correlates with early recurrence of resectable hepatocellular carcinoma. Liver Int. 2019, 39, 1682-1691. [CrossRef]

254. Lee, C.H.; Su, S.Y.; Sittampalam, K.; Chen, P.C.H.; Petersson, F.; Kao, Y.C.; Carpenter, T.O.; Hsieh, T.H.; Konishi, E.; Tsai, J.W.; et al. Frequent overexpression of klotho in fusion-negative phosphaturic mesenchymal tumors with tumorigenic implications. Mod. Pathol. 2020, 33, 858-870. [CrossRef]

255. Ronca, R.; Di Salle, E.; Giacomini, A.; Leali, D.; Alessi, P.; Coltrini, D.; Ravelli, C.; Matarazzo, S.; Ribatti, D.; Vermi, W.; et al. Long Pentraxin-3 Inhibits Epithelial-Mesenchymal Transition in Melanoma Cells. Mol. Cancer Ther. 2013, 12, 2760-2771. [CrossRef]

256. Suvannasankha, A.; Tompkins, D.R.; Edwards, D.F.; Petyaykina, K.V.; Crean, C.D.; Fournier, P.G.; Parker, J.M.; Sandusky, G.E.; Ichikawa, S.; Imel, E.A.; et al. FGF23 is elevated in multiple myeloma and increases heparanase expression by tumor cells. Oncotarget 2015, 6, 19647-19660. [CrossRef] [PubMed]

257. Liu, Z.; Zhang, H.; Ding, S.T.; Qi, S.S.; Liu, S.; Sun, D.Q.; Dong, W.; Yin, L.; Li, M.J.; Zhao, X.B.; et al. Klotho inhibits androgen/androgen receptor-associated epithelial-mesenchymal transition in prostate cancer through inactivation of ERK1/2 signaling. Oncol. Rep. 2018, 40, 217-225. [CrossRef] [PubMed]

258. Trost, N.; Pena-Llopis, S.; Koirala, S.; Stojan, J.; Potts, P.R.; Tacer, K.F.; Martinez, E.D. Gamma Klotho is a novel marker and cell survival factor in a subset of triple negative breast cancers. Oncotarget 2016, 7, 2611-2628. [CrossRef] [PubMed]

259. Choy, C.T.; Kim, H.; Lee, J.Y.; Williams, D.M.; Palethorpe, D.; Fellows, G.; Wright, A.J.; Laing, K.; Bridges, L.R.; Howe, F.A.; et al. Anosmin-1 contributes to brain tumor malignancy through integrin signal pathways. Endocr. Relat. Cancer 2014, 21, 85-99. [CrossRef]

260. Kilkenny, D.M.; Rocheleau, J.V. Fibroblast growth factor receptor-1 signaling in pancreatic islet beta-cells is modulated by the extracellular matrix. Mol. Endocrinol. 2008, 22, 196-205. [CrossRef]

261. Quintanal-Villalonga, A.; Ojeda-Marquez, L.; Marrugal, A.; Yague, P.; Ponce-Aix, S.; Salinas, A.; Carnero, A.; Ferrer, I.; MolinaPinelo, S.; Paz-Ares, L. The FGFR4-388arg Variant Promotes Lung Cancer Progression by N-Cadherin Induction. Sci. Rep. 2018, 8. [CrossRef] [PubMed]

262. Zhang, Y.; Sawada, T.; Jing, X.F.; Yokote, H.; Yan, X.M.; Sakaguchi, K. Regulation of ephexin1, a guanine nucleotide exchange factor of Rho family GTPases, by fibroblast growth factor receptor-mediated tyrosine phosphorylation. J. Biol. Chem. 2007, 282, 31103-31112. [CrossRef] [PubMed]

263. Kucinska, M.; Porebska, N.; Lampart, A.; Latko, M.; Knapik, A.; Zakrzewska, M.; Otlewski, J.; Opalinski, L. Differential regulation of fibroblast growth factor receptor 1 trafficking and function by extracellular galectins. Cell Commun. Signal. 2019, 17. [CrossRef] [PubMed]

264. Song, K.H.; Park, M.S.; Nandu, T.S.; Gadad, S.; Kim, S.C.; Kim, M.Y. GALNT14 promotes lung-specific breast cancer metastasis by modulating self-renewal and interaction with the lung microenvironment. Nat. Commun. 2016, 7. [CrossRef]

265. Mori, S.; Tran, V.; Nishikawa, K.; Kaneda, T.; Hamada, Y.; Kawaguchi, N.; Fujita, M.; Takada, Y.K.; Matsuura, N.; Zhao, M.; et al. A Dominant-Negative FGF1 Mutant (the R50E Mutant) Suppresses Tumorigenesis and Angiogenesis. PLoS ONE 2013, 8. [CrossRef]

266. Mori, S.; Kodaira, M.; Ito, A.; Okazaki, M.; Kawaguchi, N.; Hamada, Y.; Takada, Y.; Matsuura, N. Enhanced Expression of Integrin alpha v beta 3 Induced by TGF-beta Is Required for the Enhancing Effect of Fibroblast Growth Factor 1 (FGF1) in TGF-beta-Induced Epithelia-lMesenchymal Transition (EMT) in Mammary Epithelial Cells. PLoS ONE 2015, 10. [CrossRef]

267. Brown, W.S.; Tan, L.; Smith, A.; Gray, N.S.; Wendt, M.K. Covalent Targeting of Fibroblast Growth Factor Receptor Inhibits Metastatic Breast Cancer. Mol. Cancer Ther. 2016, 15, 2096-2106. [CrossRef] [PubMed]

268. Mohanan, V.; Temburni, M.K.; Kappes, J.C.; Galileo, D.S. L1CAM stimulates glioma cell motility and proliferation through the fibroblast growth factor receptor. Clin. Exp. Metastasis 2013, 30, 507-520. [CrossRef]

269. Anderson, H.J.; Galileo, D.S. Small-molecule inhibitors of FGFR, integrins and FAK selectively decrease L1CAM-stimulated glioblastoma cell motility and proliferation. Cell. Oncol. 2016, 39, 229-242. [CrossRef] 
270. Suyama, K.; Shapiro, I.; Guttman, M.; Hazan, R.B. A signaling pathway leading to metastasis is controlled by N-cadherin and the FGF receptor. Cancer Cell 2002, 2, 301-314. [CrossRef]

271. Hulit, J.; Suyama, K.; Chung, S.; Keren, R.; Agiostratidou, G.; Shan, W.S.; Dong, X.Y.; Williams, T.M.; Lisanti, M.P.; Knudsen, K.; et al. N-cadherin signaling potentiates mammary tumor metastasis via enhanced extracellular signal-regulated kinase activation. Cancer Res. 2007, 67, 3106-3116. [CrossRef] [PubMed]

272. Abdullah, A.; Akhand, S.S.; Paez, J.S.P.; Brown, W.; Pan, L.; Libring, S.; Badamy, M.; Dykuizen, E.; Solorio, L.; Tao, W.A.; et al. Epigenetic targeting of neuropilin-1 prevents bypass signaling in drug-resistant breast cancer. Oncogene 2021, 40, 322-333. [CrossRef] [PubMed]

273. Das, T.K.; Cagan, R.L. KIF5B-RET Oncoprotein Signals through a Multi-kinase Signaling Hub. Cell Rep. 2017, $20,2368-2383$. [CrossRef]

274. Knelson, E.H.; Gaviglio, A.L.; Tewari, A.K.; Armstrong, M.B.; Mythreye, K.; Blobe, G.C. Type III TGF-beta receptor promotes FGF2-mediated neuronal differentiation in neuroblastoma. J. Clin. Investig. 2013, 123, 4786-4798. [CrossRef] [PubMed]

275. Smith, M.P.; Ferguson, H.R.; Ferguson, J.; Zindy, E.; Kowalczyk, K.M.; Kedward, T.; Bates, C.; Parsons, J.; Courjal, J.; Chandler, S.; et al. Reciprocal Priming between RTKs within Recycling Endosomes Orchestrates Cellular Signaling Outputs. bioRxiv 2021. [CrossRef]

276. Meyer, A.N.; Gastwirt, R.F.; Schlaepfer, D.D.; Donoghue, D.J. The cytoplasmic tyrosine kinase Pyk2 as a novel effector of fibroblast growth factor receptor 3 activation. J. Biol. Chem. 2004, 279, 28450-28457. [CrossRef]

277. Salazar, L.; Kashiwada, T.; Krejci, P.; Meyer, A.N.; Casale, M.; Hallowell, M.; Wilcox, W.R.; Donoghue, D.J.; Thompson, L.M. Fibroblast Growth Factor Receptor 3 Interacts with and Activates TGF beta-Activated Kinase 1 Tyrosine Phosphorylation and NFkB Signaling in Multiple Myeloma and Bladder Cancer. PLoS ONE 2014, 9. [CrossRef]

278. Cavallaro, U.; Niedermeyer, J.; Fuxa, M.; Christofori, G. N-CAM modulates tumour-cell adhesion to matrix by inducing FGF-receptor signalling. Nat. Cell Biol. 2001, 3, 650-657. [CrossRef]

279. Ezzat, S.; Zheng, L.; Asa, S.L. Pituitary tumor-derived fibroblast growth factor receptor 4 isoform disrupts neural cell-adhesion molecule/N-cadherin signaling to diminish cell adhesiveness: A mechanism underlying pituitary neoplasia. Mol. Endocrinol. 2004, 18, 2543-2552. [CrossRef]

280. Xu, S.S.; Xu, H.X.; Wang, W.Q.; Li, S.; Li, H.; Li, T.J.; Zhang, W.H.; Yu, X.J.; Liu, L. The role of collagen in cancer: From bench to bedside. J. Transl. Med. 2019, 17. [CrossRef]

281. Efthymiou, G.; Saint, A.; Ruff, M.; Rekad, Z.; Ciais, D.; Van Obberghen-Schilling, E. Shaping Up the Tumor Microenvironment With Cellular Fibronectin. Front. Oncol. 2020, 10. [CrossRef] [PubMed]

282. Zou, L.; Cao, S.; Kang, N.L.; Huebert, R.C.; Shah, V.H. Fibronectin Induces Endothelial Cell Migration through beta 1 Integrin and Src-dependent Phosphorylation of Fibroblast Growth Factor Receptor-1 at Tyrosines 653/654 and 766. J. Biol. Chem. 2012, 287, 7190-7202. [CrossRef] [PubMed]

283. Mendez-Huergo, S.P.; Blidner, A.G.; Rabinovich, G.A. Galectins: Emerging regulatory checkpoints linking tumor immunity and angiogenesis. Curr. Opin. Immunol. 2017, 45, 8-15. [CrossRef] [PubMed]

284. Desgrosellier, J.S.; Cheresh, D.A. Integrins in cancer: Biological implications and therapeutic opportunities. Nat. Rev. Cancer 2010, 10, 9-22. [CrossRef]

285. Mori, S.; Wu, C.Y.; Yamaji, S.; Saegusa, J.; Shi, B.; Ma, Z.; Kuwabara, Y.; Lam, K.S.; Isseroff, R.R.; Akada, Y.K.; et al. Direct binding of integrin alpha v beta 3 to FGF1 plays a role in FGF1 signaling. J. Biol. Chem. 2008, 283, 18066-18075. [CrossRef] [PubMed]

286. Geissinger, E.; Weisser, C.; Fischer, P.; Schartl, M.; Wellbrock, C. Autocrine stimulation by osteopontin contributes to antiapoptotic signalling of melanocytes in dermal collagen. Cancer Res. 2002, 62, 4820-4828.

287. Ruan, S.S.; Lin, M.; Zhu, Y.; Lum, L.; Thakur, A.; Jin, R.M.; Shao, W.L.; Zhang, Y.L.; Hu, Y.Y.; Huang, S.; et al. Integrin beta 4-Targeted Cancer Immunotherapies Inhibit Tumor Growth and Decrease Metastasis. Cancer Res. 2020, 80, 771-783. [CrossRef]

288. Ge, D.; Kong, X.Q.; Liu, W.Y.; Zhao, J.; Su, L.; Zhang, S.L.; Zhang, Y.; Zhao, B.X.; Miao, J.Y. Phosphorylation and nuclear translocation of integrin beta 4 induced by a chemical small molecule contribute to apoptosis in vascular endothelial cells. Apoptosis 2013, 18, 1120-1131. [CrossRef]

289. Gonzalez-Martinez, D.; Kim, S.H.; Hu, Y.L.; Guimond, S.; Schofield, J.; Winyard, P.; Vannelli, G.B.; Turnbull, J.; Bouloux, P.M. Anosmin-1 modulates fibroblast growth factor receptor 1 signaling in human gonadotropin-releasing hormone olfactory neuroblasts through a heparan sulfate-dependent mechanism. J. Neurosci. 2004, 24, 10384-10392. [CrossRef]

290. Korsensky, L.; Ron, D. Regulation of FGF signaling: Recent insights from studying positive and negative modulators. Semin. Cell Dev. Biol. 2016, 53, 101-114. [CrossRef]

291. Wai Wong, C.; Dye, D.E.; Coombe, D.R. The Role of Immunoglobulin Superfamily Cell Adhesion Molecules in Cancer Metastasis. Int. J. Cell Biol. 2012, 2012, 340296. [CrossRef] [PubMed]

292. Francavilla, C.; Cattaneo, P.; Berezin, V.; Bock, E.; Ami, D.; de Marco, A.; Christofori, G.; Cavallaro, U. The binding of NCAM to FGFR1 induces a specific cellular response mediated by receptor trafficking. J. Cell Biol. 2009, 187, 1101-1116. [CrossRef] [PubMed]

293. Zivotic, M.; Tampe, B.; Muller, G.; Muller, C.; Lipkovski, A.; Xu, X.B.; Nyamsuren, G.; Zeisberg, M.; Markovic-Lipkovski, J. Modulation of NCAM/FGFR1 signaling suppresses EMT program in human proximal tubular epithelial cells. PLoS ONE 2018, 13. [CrossRef] [PubMed] 
294. Yu, W.N.; Yang, L.; Li, T.; Zhang, Y. Cadherin Signaling in Cancer: Its Functions and Role as a Therapeutic Target. Front. Oncol. 2019, 9. [CrossRef]

295. Sanchez-Heras, E.; Howell, F.V.; Williams, G.; Doherty, P. The fibroblast growth factor receptor acid box is essential for interactions with N-cadherin and all of the major isoforms of neural cell adhesion molecule. J. Biol. Chem. 2006, 281, 35208-35216. [CrossRef] [PubMed]

296. Agiostratidou, G.; Hulit, J.; Phillips, G.R.; Hazan, R.B. Differential cadherin expression: Potential markers for epithelial to mesenchymal transformation during tumor progression. J. Mammary Gland Biol. Neoplasia 2007, 12, 127-133. [CrossRef]

297. Nguyen, T.; Mege, R.M. N-Cadherin and Fibroblast Growth Factor Receptors crosstalk in the control of developmental and cancer cell migrations. Eur. J. Cell Biol. 2016, 95, 415-426. [CrossRef]

298. Qian, X.; Anzovino, A.; Kim, S.; Suyama, K.; Yao, J.; Hulit, J.; Agiostratidou, G.; Chandiramani, N.; McDaid, H.M.; Nagi, C.; et al. $\mathrm{N}$-cadherin/FGFR promotes metastasis through epithelial-to-mesenchymal transition and stem/progenitor cell-like properties. Oncogene 2014, 33, 3411-3421. [CrossRef]

299. Quintanal-Villalonga, A.; Ferrer, I.; Guruceaga, E.; Cirauqui, C.; Marrugal, A.; Ojeda, L.; Garcia, S.; Zugazagoitia, J.; MunozGalvan, S.; Lopez-Rios, F.; et al. FGFR1 and FGFR4 oncogenicity depends on n-cadherin and their co-expression may predict FGFR-targeted therapy efficacy. Ebiomedicine 2020, 53. [CrossRef]

300. Boscher, C.; Mege, R.M. Cadherin-11 interacts with the FGF receptor and induces neurite outgrowth through associated downstream signalling. Cell. Signal. 2008, 20, 1061-1072. [CrossRef]

301. Nguyen, T.; Duchesne, L.; Narayana, G.; Boggetto, N.; Fernig, D.D.; Murade, C.U.; Ladoux, B.; Mege, R.M. Enhanced cell-cell contact stability and decreased $\mathrm{N}$-cadherin-mediated migration upon fibroblast growth factor receptor-N-cadherin cross talk. Oncogene 2019, 38, 6283-6300. [CrossRef] [PubMed]

302. El-Hariry, I.; Pignatelli, M.; Lemoine, N.R. FGF-1 and FGF-2 regulate the expression of E-cadherin and catenins in pancreatic adenocarcinoma. Int. J. Cancer 2001, 94, 652-661. [CrossRef] [PubMed]

303. Bryant, D.M.; Wylie, F.G.; Stow, J.L. Regulation of endocytosis, nuclear translocation, and signaling of fibroblast growth factor receptor 1 by E-cadherin. Mol. Biol. Cell 2005, 16, 14-23. [CrossRef] [PubMed]

304. Bojesen, K.B.; Clausen, O.; Rohde, K.; Christensen, C.; Zhang, L.J.; Li, S.Z.; Kohler, L.; Nielbo, S.; Nielsen, J.; Gjorlund, M.D.; et al Nectin-1 Binds and Signals through the Fibroblast Growth Factor Receptor. J. Biol. Chem. 2012, 287, 37420-37433. [CrossRef] [PubMed]

305. Kedashiro, S.; Sugiura, A.; Mizutani, K.; Takai, Y. Nectin-4 cis-interacts with ErbB2 and its trastuzumab-resistant splice variants, enhancing their activation and DNA synthesis. Sci. Rep. 2019, 9. [CrossRef] [PubMed]

306. Tsang, M.; Friesel, R.; Kudoh, T.; Dawid, I.B. Identification of Sef, a novel modulator of FGF signalling. Nat. Cell Biol. 2002, 4, 165-169. [CrossRef]

307. Ren, Y.M.; Li, Z.Y.; Rong, Z.L.; Cheng, L.; Li, Y.H.; Wang, Z.; Chang, Z.J. Tyrosine 330 in hSef is critical for the localization and the inhibitory effect on FGF signaling. Biochem. Biophys. Res. Commun. 2007, 354, 741-746. [CrossRef]

308. Xiong, S.Q.; Zhao, Q.H.; Rong, Z.L.; Huang, G.R.; Huang, Y.L.; Chen, P.L.; Zhang, S.P.; Liu, L.; Chang, Z.J. hSef inhibits PC-12 cell differentiation by interfering with Ras-mitogen-activated protein kinase MAPK signaling. J. Biol. Chem. 2003, 278, 50273-50282. [CrossRef]

309. Ren, Y.M.; Cheng, L.; Rong, Z.L.; Li, Z.Y.; Li, Y.H.; Li, H.G.; Wang, Z.; Chang, Z.J. hSef co-localizes and interacts with Ras in the inhibition of Ras/MAPK signaling pathway. Biochem. Biophys. Res. Commun. 2006, 347, 988-993. [CrossRef]

310. Ren, Y.M.; Cheng, L.; Rong, Z.L.; Li, Z.Y.; Li, Y.H.; Zhang, X.J.; Xiong, S.Q.; Hu, J.; Fu, X.Y.; Chang, Z.J. HSef potentiates EGF-mediated MATK signaling through affecting EGFR trafficking and degradation. Cell. Signal. 2008, 20, 518-533. [CrossRef]

311. Torii, S.; Kusakabe, M.; Yamamoto, T.; Maekawa, M.; Nishida, E. Sef is a spatial regulator for Ras/MAP kinase signaling. Dev. Cell 2004, 7, 33-44. [CrossRef] [PubMed]

312. He, Q.; Gong, Y.; Gower, L.; Yang, X.H.; Friesel, R.E. Sef Regulates Epithelial-Mesenchymal Transition in Breast Cancer Cells. J. Cell. Biochem. 2016, 117, 2346-2356. [CrossRef] [PubMed]

313. Hori, S.; Wadhwa, K.; Pisupati, V.; Zecchini, V.; Ramos-Montoya, A.; Warren, A.Y.; Neal, D.E.; Gnanapragasam, V.J. Loss of hSef promotes metastasis through upregulation of EMT in prostate cancer. Int. J. Cancer 2017, 140, 1881-1887. [CrossRef] [PubMed]

314. Murphy, T.; Darby, S.; Mathers, M.E.; Gnanapragasam, V.J. Evidence for distinct alterations in the FGF axis in prostate cancer progression to an aggressive clinical phenotype. J. Pathol. 2010, 220, 452-460. [CrossRef]

315. Zhang, H.; Zhao, X.B.; Yan, L.; Li, M.J. Similar expression to FGF (Sef) reduces endometrial adenocarcinoma cells proliferation via inhibiting fibroblast growth factor 2-mediated MAPK/ERK signaling pathway. Gynecol. Oncol. 2011, 122, 669-674. [CrossRef]

316. Chi, L.H.; Burrows, A.D.; Anderson, R.L. Bone morphogenetic protein signaling in breast cancer progression. Growth Factors 2019, 37, 12-28. [CrossRef]

317. Montesano, R.; Sarkozi, R.; Schramek, H. Bone morphogenetic protein-4 strongly potentiates growth factor-induced proliferation of mammary epithelial cells. Biochem. Biophys. Res. Commun. 2008, 374, 164-168. [CrossRef]

318. Jubb, A.M.; Strickland, L.A.; Liu, S.D.; Mak, J.; Schmidt, M.; Koeppen, H. Neuropilin-1 expression in cancer and development. J. Pathol. 2012, 226, 50-60. [CrossRef]

319. Del Piccolo, N.; Sarabipour, S.; Hristova, K. A New Method to Study Heterodimerization of Membrane Proteins and Its Application to Fibroblast Growth Factor Receptors. J. Biol. Chem. 2017, 292, 1288-1301. [CrossRef] [PubMed] 
320. Bellot, F.; Crumley, G.; Kaplow, J.M.; Schlessinger, J.; Jaye, M.; Dionne, C.A. Ligand-induced transphosphorylation between different FGF receptors. EMBO J. 1991, 10, 2849-2854. [CrossRef]

321. Kennedy, S.P.; Hastings, J.F.; Han, J.Z.R.; Croucher, D.R. The Under-Appreciated Promiscuity of the Epidermal Growth Factor Receptor Family. Front. Cell Dev. Biol. 2016, 4. [CrossRef] [PubMed]

322. Yokote, H.; Fujita, K.; Jing, X.F.; Sawada, T.; Liang, S.T.; Yao, L.; Yan, X.M.; Zhang, Y.Q.; Schlessinger, J.; Sakaguchi, K. Transactivation of EphA4 and FGF receptors mediated by direct interactions between their cytoplasmic domains. Proc. Natl. Acad. Sci. USA 2005, 102, 18866-18871. [CrossRef] [PubMed]

323. Sawada, T.; Jing, X.F.; Zhang, Y.Q.; Shimada, E.; Yokote, H.; Miyajima, M.; Sakaguchi, K. Ternary complex formation of EphA4, FGFR and FRS2 alpha plays an important role in the proliferation of embryonic neural stem/progenitor cells. Genes Cells 2010, 15, 297-311. [CrossRef] [PubMed]

324. Paul, M.D.; Grubb, H.N.; Hristova, K. Quantifying the strength of heterointeractions among receptor tyrosine kinases from different subfamilies: Implications for cell signaling. J. Biol. Chem. 2020, 295, 9917-9933. [CrossRef]

325. Fukai, J.; Yokote, H.; Yamanaka, R.; Arao, T.; Nishio, K.; Itakura, T. EphA4 promotes cell proliferation and migration through a novel EphA4-FGFR1 signaling pathway in the human glioma U251 cell line. Mol. Cancer Ther. 2008, 7, 2768-2778. [CrossRef] [PubMed]

326. Bong, Y.S.; Park, Y.H.; Lee, H.S.; Mood, K.; Ishimura, A.; Daar, I.O. Tyr-298 in ephrinB1 is critical for an interaction with the Grb4 adaptor protein. Biochem. J. 2004, 377, 499-507. [CrossRef] [PubMed]

327. Rosenberg, I.M.; Goke, M.; Kanai, M.; Reinecker, H.C.; Podolsky, S.K. Epithelial cell kinase-B61: An autocrine loop modulating intestinal epithelial migration and barrier function. Am. J. Physiol. Gastrointest. Liver Physiol. 1997, 273, G824-G832. [CrossRef] [PubMed]

328. Faraone, D.; Aguzzi, M.S.; Ragone, G.; Russo, K.; Capogrossi, M.C.; Facchiano, A. Heterodimerization of FGF-receptor 1 and PDGF-receptor-alpha: A novel mechanism underlying the inhibitory effect of PDGF-BB on FGF-2 in human cells. Blood 2006, 107, 1896-1902. [CrossRef]

329. Chen, P.Y.; Simons, M.; Friesel, R. FRS2 via Fibroblast Growth Factor Receptor 1 Is Required for Platelet-derived Growth Factor Receptor beta-mediated Regulation of Vascular Smooth Muscle Marker Gene Expression. J. Biol. Chem. 2009, $284,15980-15992$. [CrossRef] [PubMed]

330. De Marchis, F.; Ribatti, D.; Giampietri, C.; Lentini, A.; Faraone, D.; Scoccianti, M.; Capogrossi, M.C.; Facchiano, A. Platelet-derived growth factor inhibits basic fibroblast growth factor angiogenic properties in vitro and in vivo through its alpha receptor. Blood 2002, 99, 2045-2053. [CrossRef]

331. Facchiano, A.; De Marchis, F.; Turchetti, E.; Facchiano, F.; Guglielmi, M.; Denaro, A.; Palumbo, R.; Scoccianti, M.; Capogrossi, M.C. The chemotactic and mitogenic effects of platelet-derived growth factor-BB on rat aorta smooth muscle cells are inhibited by basic fibroblast growth factor. J. Cell Sci. 2000, 113, 2855-2863. [CrossRef]

332. Ark, A.V.; Cao, J.C.; Li, X.H. TGF-beta receptors: In and beyond TGF-beta signaling. Cell. Signal. 2018, 52, 112-120. [CrossRef]

333. Zhang, H.R.; Wang, X.D.; Yang, X.; Chen, D.; Hao, J.; Cao, R.; Wu, X.Z. An FGFR inhibitor converts the tumor promoting effect of TGF-beta by the induction of fibroblast-associated genes of hepatoma cells. Oncogene 2017, 36, 3831-3841. [CrossRef] [PubMed]

334. Akatsu, Y.; Takahashi, N.; Yoshimatsu, Y.; Kimuro, S.; Muramatsu, T.; Katsura, A.; Maishi, N.; Suzuki, H.I.; Inazawa, J.; Hida, K.; et al. Fibroblast growth factor signals regulate transforming growth factor-beta-induced endothelial-to-myofibroblast transition of tumor endothelial cells via Elk1. Mol. Oncol. 2019, 13, 1706-1724. [CrossRef] [PubMed]

335. Bordignon, P.; Bottoni, G.; Xu, X.Y.; Popescu, A.S.; Truan, Z.; Guenova, E.; Kofler, L.; Jafari, P.; Ostano, P.; Roecken, M.; et al. Dualism of FGF and TGF-beta Signaling in Heterogeneous Cancer-Associated Fibroblast Activation with ETV1 as a Critical Determinant. Cell Rep. 2019, 28, 2358. [CrossRef] [PubMed]

336. Mukhopadhyay, H.; Lee, N.Y. Multifaceted roles of TAK1 signaling in cancer. Oncogene 2020, 39, 1402-1413. [CrossRef] [PubMed]

337. Butti, R.; Das, S.; Gunasekaran, V.P.; Yadav, A.S.; Kumar, D.; Kundu, G.C. Receptor tyrosine kinases (RTKs) in breast cancer: Signaling, therapeutic implications and challenges. Mol. Cancer 2018, 17. [CrossRef] [PubMed]

338. Huang, K.L.; Li, S.Q.; Mertins, P.; Cao, S.; Gunawardena, H.P.; Ruggles, K.V.; Mani, D.R.; Clauser, K.R.; Tanioka, M.; Usary, J.; et al. Proteogenomic integration reveals therapeutic targets in breast cancer xenografts. Nat. Commun. 2017, 8. [CrossRef]

339. Mertins, P.; Mani, D.R.; Ruggles, K.V.; Gillette, M.A.; Clauser, K.R.; Wang, P.; Wang, X.L.; Qiao, J.W.; Cao, S.; Petralia, F.; et al. Proteogenomics connects somatic mutations to signalling in breast cancer. Nature 2016, 534, 55. [CrossRef]

340. Arakaki, A.K.S.; Pan, W.A.; Trejo, J. GPCRs in Cancer: Protease-Activated Receptors, Endocytic Adaptors and Signaling. Int. J. Mol. Sci. 2018, 19, 1886. [CrossRef]

341. Haxho, F.; Neufeld, R.J.; Szewczuk, M.R. Neuraminidase-1: A novel therapeutic target in multistage tumorigenesis. Oncotarget 2016, 7, 40860-40903. [CrossRef] [PubMed] 